\title{
MISREADING MCCULLOCH V. MARYLAND
}

\author{
David S. Schwartz*
}

\begin{abstract}
The conventional reading of McCulloch $\mathrm{v}$. Maryland maintains that the opinion established the constitutional foundations of a broad conception of congressional power. This reading of McCulloch is part of a broader depiction of Chief Justice John Marshall as an "aggressive nationalist" and "nation builder" whose "spacious" interpretations of the powers of Congress contributed significantly to national unification and growth.
\end{abstract}

This Article argues that the conventional account seriously misreads McCulloch by exaggerating its nationalism. Marshall, though a nationalist, was far more cautious and moderate in his views than the standard story holds, and the text of McCulloch reflects significant ambivalence about most of its most celebrated principles. In crafting the McCulloch opinion, Marshall systematically steered a moderate course relative to the arguments urged by the Bank's defenders and other prominent nationalists of the time. In particular, McCulloch avoided taking a clear position on any of the leading constitutional controversies of his day-internal improvements, a national power over the money supply, and the scope of the Commerce Clause. Marshall also stopped conspicuously short of endorsing the Bank's lawyers' arguments for an extreme version of judicial deference to Congress's choice of means and its interpretation of the scope of its own powers.

\section{TABLE OF CONTENTS}

INTRODUCTION

I. ASSESSING MCCULLOCH'S NATIONALISM .................................... 7

A. The Conventional View: McCulloch as "Aggressive Nationalism"... 8

B. Aggressive versus Defensive Nationalism ......................... 13

C. Defensive Nationalism in McCulloch............................. 15

* Foley \& Lardner-Bascom Professor of Law, University of Wisconsin Law School. All rights reserved. I am grateful to the following colleagues who have read and commented on drafts of this Article: Bill Nelson, R.B. Bernstein, and the participants in the NYU Legal History Colloquium; and to Will Baude, Andy Coan, Anuj Desai, Mark Graber, Charles Hobson, Mark Killenbeck, John Mikhail, Sheldon Nahmod, Gerard Magliocca, Kent Newmyer, Chris Schmidt, Brad Snyder, Vicky Saker Woeste, and BethAnne Yeager; and to the participants in the Wisconsin law faculty workshop, Ann Althouse, Alexandra Huneeus, Heinz Klug, Gwyn Leachman, Megan McDermott, Richard Monette, Asifa Quraishi-Landes, Miriam Seifter, Mitra Sharafi, Rob Yablon, and Jason Yackee. I benefited greatly from the research assistance of Bonnie Shucha and Peter Wehrle of the UW Law Library, and law students James Meadows, Chelsey Metcalf, Renee Parton, and Nicholas Sideras. 
1. Nationalist versus Compact Theory ............................ 17

2. Taxation and Supremacy ..................................... 19

3. Constitutional Interpretation .................................. 22

D. McCulloch's "Aggressive" Nationalism .......................... 23

\section{MCCULLOCH'S CONTEXT: THE BANK CONTROVERSY AND}

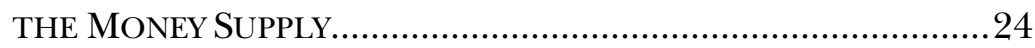

A. Constitutional Foundations ......................................... 25

B. The First Bank and Hamiltonian Political Economy............ 27

1. Hamilton's Bank Report ........................................ 27

2. Hamilton's Opinion on Constitutionality.................... 31

3. Charter and Expiration........................................... 35

4. Marshall and the First Bank's History........................ 38

C. The War of 1812 and the Call for a Second Bank............... 40

D. Constitutional Arguments: Madison, Calhoun, and the Money Supply .................................................. 42

III. MCCULLOCH'S CONTEXT: INTERNAL IMPROVEMENTS ..............46

A. The Internal Improvements Controversy ........................ 47

B. McCulloch and Internal Improvements .......................... 50

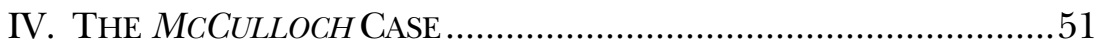

A. The Litigation ...................................................... 51

B. The Oral Arguments......................................... 52

C. The Decision: Grounding the Bank ............................ 57

D. The Decision: Internal Improvements............................ 63

E. The Decision: Implied Powers ........................................ 68

1. The Definition of Implied Powers ................................ 68

2. The Necessary and Proper Clause and Judicial Review .... 72

3. Implied versus Enumerated Powers............................. 79

V. EPILOGUE: INTERNAL IMPROVEMENTS AFTER MCCULLOCH ......81

A. Marshall, Monroe, and the Cumberland Road Tollgate Veto.. 81

1. Monroe's Pamphlet.................................................. 82

2. The "Advisory Opinion" ....................................... 85

B. Gibbons v. Ogden...................................................... 88

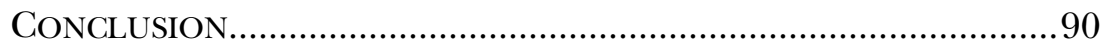




\section{INTRODUCTION}

McCulloch v. Maryland is the "most canonical" of cases in American constitutional law. ${ }^{2}$ It is also the most misunderstood.

Everyone accepts McCulloch $v$. Maryland as a decision of the highest importance in American constitutional law. For over a century, constitutional scholars have agreed with James Bradley Thayer's appraisal in his 1901 biographical sketch of Chief Justice John Marshall, that McCulloch was "probably [Marshall's] greatest opinion" and "the chief illustration" of Marshall's "giving free scope to the power of the national government." "In 2014, Sanford Levinson spoke for the continuing consensus, when he said, "I personally regard [McCulloch] as the richest and most important single opinion of the United States Supreme Court in our entire history."

Why is McCulloch seen as so important? The answer is not hard to discern. If Marshall was a "nation builder" as many constitutional scholars like to assert, McCulloch was his signature nation-building achievement. ${ }^{5}$ The particulars of the consensus view are captured by legal historian Richard Ellis:

[O]f [U.S. Supreme Court] decisions none has proved to be more significant than McCulloch $v$. Maryland (1819) ... Unquestionably, much of the praise for the decision, if extravagant, is merited .... Among other things, it provides an enduring nationalist interpretation of the origins and nature of the Constitution and the union and a broad definition of the necessary and proper clause (Article I, section 8), which has laid the foundation for the living Constitution, and with it the means for an almost infinite increase in the powers of the federal government. ${ }^{6}$

We can call this consensus view the "aggressive nationalism thesis." The principal tenets of this thesis are that McCulloch (1) endorses a

$1 \quad 17$ U.S. (4 Wheat.) 316 (1819).

2 Jack M. Balkin \& Sanford Levinson, Commentary, The Canons of Constitutional Law, 111 HARV. L. REV. 963, 987 (1998).

3 James Bradley Thayer, Thayer on Marshall (1901), reprinted in JAMES BRADLEY THAYER, Oliver WeNDELl Holmes AND FElix FrankfurTer ON JOHN MARSHALl 66 (1967).

4 Sanford Levinson, A Close Reading of McCulloch v. Maryland, Offering in Harvard Law School Course Catalog, HARvard Law SCHOOL (Sept. 17, 2015, 1:31 PM), https://helios. law.harvard.edu/coursecatalogs/hls-course-catalog-2014-2015.pdf. For similar opinions in intervening years, see, for example, R. Kent Newmyer, John Marshall and the Southern Constitutional Tradition, in AN UNCERTAIN TRADITION: CONSTITUTIONALISM AND THE HISTORY OF THE SOUTH 105, 108 (Kermit L. Hall \& James W. Ely, Jr. eds., 1989) (ranking McCulloch as "possibly the most far-reaching decision ever handed down by the Supreme Court"); infra notes 20-22 and accompanying text.

$5 \quad$ See infra text accompanying note 24.

6 RichaRd E. ELLIS, AGGRESSIVE NATIONALISM 3-4 (2007).

7 I derive this label from Ellis's fine, though aggressively titled, book-length study of $\mathrm{McCul}$ loch. Id. 
broad interpretation of national powers, and (2) established that broad interpretation in our constitutional doctrine once and for all. In this Article, I argue that the first of these tenets is greatly exaggerated if not false, and that the aggressive nationalism thesis is greatly overstated if not outright wrong. ${ }^{8}$

The aggressive nationalism thesis has been reinforced by existing scholarship, which has always focused on the narrowly framed yes/no question of the constitutionality of the Bank, and thereby failed to ask the right questions. Because McCulloch reached the result sought by nationalists-the "yes" answer, upholding congressional power to charter a national bank-the opinion seems to fit comfortably within an aggressive nationalism interpretation. But legal historians have long shown that the constitutionality of the Bank in 1819 was not a controversial position, having been accepted by congressional majorities and all five presidential administrations as of 1819. ${ }^{9}$ Thus $\mathrm{McCul}$ loch's result by itself fit within a broad political consensus, and does not necessarily tell us as much about Marshall's nationalism as we have assumed. At the same time, historical scholarship on McCulloch has not dug deeper by asking how nationalistic Marshall's "yes" really was: whether the decision was aggressively nationalistic in comparison to the arguments available to or urged on the Marshall Court. Unfortunately, constitutional scholars take for granted that we have such a thorough understanding of the case that such an exercise would yield no insight. Thus, "the opinion's fame has not generated a commensurate level of academic commentary on the decision that the Court actually reached." ${ }^{10}$

In this Article, I present a fresh and significantly revised reading of McCulloch by examining the decision in two important historical contexts. $^{11}$ First, I examine the history of the First and Second National Banks, not as mere background, but in order to understand the full scope of the constitutional arguments in the McCulloch decision. I focus on the arguments made over the years, and at the McCulloch oral argument itself, for sustaining the Bank. The purpose is not to rehash the well-established point that Marshall's opinion

8 The second tenet is likewise exaggerated or false, but requires its own separate articlelength treatment, which I undertake elsewhere.

9 See infra notes 102-03 and accompanying text.

10 Gerard N. Magliocca, A New Approach to Congressional Power: Revisiting the Legal Tender Cases, 95 GEO. L.J. 119, 125 (2006).

11 Professor Levinson may be one of the few constitutional scholars who believes that a close reading of McCulloch can teach us something new. He has devoted a recent law school seminar to such a project: "It is almost literally the case that each of [McCulloch's] 72 paragraphs is worth close analysis...." Levinson, supra note 4. 
summarizes the arguments of Alexander Hamilton and others. ${ }^{12}$ Rather the point is to understand the limits of what Marshall actually said in McCulloch by considering the pro-Bank arguments he left out.

Second, I expand the focus beyond the narrowly framed yes/no question of the constitutionality of the Bank itself to consider three closely related questions of constitutional power lurking immediately behind McCulloch. These questions were hotly contested and hugely important. The first was national control over the monetary system. Did the Federal Government have the power to impose a uniform national currency and thereby keep tight control over the chaotic system of state banks that had become popular with Jeffersonian arriviste businessmen? The second question involved the power of Congress to undertake national infrastructure projects, known as internal improvements: did Congress have an implied power under one or more of the enumerated powers to build and maintain roads, canals and other infrastructure projects? The third question, tied closely to the first two, was the scope of the Commerce Clause. Could the commerce power be used as a basis to claim authority over the monetary system, since money is the medium of exchange? Could it be used to support congressional power over internal improvements?

If McCulloch lived up to its billing, the case should have addressed at least one, and possibly all three of the above issues-particularly the Commerce Clause-and adopted a nationalist position. The arguments for doing so were well established in the annals of congressional debates, the reports of high profile executive branch officials like Alexander Hamilton and John C. Calhoun, and the McCulloch oral arguments themselves.

However, as I will show, Marshall sidestepped or ignored one nationalist argument after another in upholding the constitutionality of the Second Bank of the United States. Marshall painstakingly avoided giving a broad interpretation to any enumerated power in a systematic effort to steer clear of any controversy over concrete questions of national power. McCulloch was vexingly non-committal on those questions. Contenting himself with upholding the Bank and refuting the most anti-federalist arguments for strict constitutional construction, Marshall declined to press matters any further.

Nor can it be said that McCulloch's holding on implied powers compensated for Marshall's cautious approach to enumerated pow-

12 See, e.g., Charles F. Hobson, The Great Chief Justice: John Marshall and the Rule OF LAW 122 (1996) ("Scarcely a passage in the first part of McCulloch could not be traced to Hamilton's advisory opinion or to some earlier writing, speech, or legal argument.”). 
ers. While Marshall famously rejected the radical anti-federalist approach to implied powers, he stopped well short of embracing the most nationalistic position. Moreover, implied powers are necessarily cabined by limits on the scope of enumerated powers, and Marshall promised, if somewhat ambiguously, that the Court would assume a significant role in policing those limits.

In Part I, I elaborate on the aggressive nationalism thesis and set out criteria for properly assessing the extent of Marshall's nationalism. I show how the historical scholarship taking a more measured view of McCulloch has had little impact on the mainstream interpretation of the case. Part of the problem is a tendency of modern scholars to confuse Marshall's defensive (state-restraining, unionpreserving) nationalism with aggressive congressional-powerexpanding nationalism.

Parts II and III re-examine the National Bank controversy, placing it in the broader context of debates touching on the commerce power, specifically the powers of the national government to regulate the money supply and to undertake internal improvements projects. I examine constitutional questions and arguments linking these issues to that of a national bank, to show both the plain implications of the McCulloch decision for these related congressional power questions, and to highlight the constitutional arguments available to Marshall at the time of McCulloch.

Part IV re-examines the $M c$ Culloch case with emphasis on the arguments actually presented to the Court. I then compare those arguments to the opinion to see which were included and which were omitted by Marshall. I show that Marshall systematically avoided taking a clear position on any of the three leading constitutional controversies and also stopped conspicuously short of endorsing the Bank's lawyers' arguments for an extreme version of judicial deference to Congress's choice of means and its interpretation of the scope of its own powers.

Part V rounds out the story of McCulloch by examining the case's lack of impact on the question of internal improvements in the years immediately following the case. I consider how two significant events-Marshall's reaction to President James Monroe's veto of a major internal improvements bill, and the decision in Gibbons v. Ogden-further undercut the aggressive nationalism interpretation of McCulloch.

The significance of this revisionist examination of McCulloch goes beyond historical accuracy in the interpretation of a canonical text. In a brief Conclusion I suggest that the conventional misreading of McCulloch raises another set of questions concerning how and why the 
aggressive nationalism thesis was created and became dominant in our constitutional law culture. ${ }^{13}$ Why is our constitutional law scholarship so committed to the idea that McCulloch helped build a nation, when the truth is that the decision did not even commit to building a road?

\section{ASSESSING MCCULLOCH'S NATIONALISM}

The conventional view of McCulloch, which I call the "aggressive nationalism thesis," maintains that McCulloch established an expansive view of national power in American constitutional law that invited or encouraged Congress to expand the national government's role in American life. But McCulloch makes several assertions of varying degrees of nationalism that modern commentators often view as an undifferentiated mass. A clear-headed assessment of Chief Jusice John Marshall's nationalism requires us to distinguish doctrines that expansively interpret the regulatory powers of Congress from those that merely assert the power of the Supreme Court to control state courts' interpretation of federal law or to block state regulation where the Constitution or a federal statute conflicts with state law.

In this Part, I first identify the claims about $M c$ Culloch's meaning that are characteristic of the aggressive nationalism thesis. I then distinguish between two forms of nationalism: one that matches the "aggressive" form attributed to McCulloch, and another that is better characterized as "defensive." ${ }^{\text {I }}$ argue that much of what is counted as Marshall's nationalism in McCulloch is in fact defensive nationalism that fails to support the aggressive nationalism thesis. To understand McCulloch on its own terms, we should identify with particularity what in McCulloch could properly be considered nationalist, and extract those elements that are properly considered aggressively nationalistic.

13 One general caveat is in order here. It is conventional in constitutional and even legal history scholarship to treat the views of Chief Justice Marshall and those of the Marshall Court as interchangeable, at least in cases where Marshall authored the opinion. This convention should perhaps give us pause-Marshall had four or five associate Justices who may have held varying views that Marshall had to accommodate, or at least to finesse, in any given opinion-perhaps accounting for some of the ambiguities we find in them. While undoubtedly a serious examination of the collective nature of Marshall Court decisions would be illuminating, it is not clear to me that such an ambitious undertaking here would affect the arguments I make in this Article. Thus, I have determined to embrace rather than resist the conventional equation of Marshall and his Court.

14 See Hobson, supra note 12, at 123 (" $[\mathrm{T}]$ he nationalism endorsed by [McCulloch] is more accurately defined in negative or defensive terms-concerned primarily with preserving the union against powerful centrifugal tendencies that constantly threatened its dissolution.”). 


\section{A. The Conventional View: McCulloch as "Aggressive Nationalism"}

The conventional wisdom maintains that McCulloch $v$. Maryland is an aggressively nationalistic decision. Half a century after James Bradley Thayer's paean to McCulloch, Justice Felix Frankfurter "follow[ed] [Thayer] in believing that the conception of the nation which Marshall derived from the Constitution and set forth in M'Culloch v. Maryland is his greatest single judicial performance." ${ }^{15}$ A few years later, Robert G. McCloskey famously opined that McCulloch is, "by almost any reckoning, the greatest decision John Marshall ever handed down."

These mid-twentieth century views influenced successive generations of scholars, and persist to this day. In the words of constitutional theorist Keith Whittington, McCulloch expressed a "sweeping nationalist vision."17 Legal historian Mark Killenbeck claims that "M'Culloch was also at the time and remains today an incredibly important holding on federal state relations ... [that] became an essential foundation for much of what followed, in particular the extraordinary expansion of federal authority that arose in the wake of [the New Deal]." " As Michael Klarman has observed, "[t]wentieth-century advocates of expansive national power have insisted that Marshall's capacious understandings of the Necessary and Proper Clause and the Commerce Clause were sufficient to accommodate the modern regulatory state." ${ }^{19}$ Eminent historians of the antebellum period, probably influenced by their law colleagues, also see McCulloch as "what may have been the most important of his many important judicial decisions," in which Marshall "made great law." ${ }^{20}$ McCulloch is presented as a "principal case" in every current constitutional law

15 Felix Frankfurter, John Marshall and the Judicial Function, 69 HARV. L. REV. 217, 219 (1955). No serious study of McCulloch should fail to address the apostrophe question. The official reports spelled the name "M'Culloch," using an upside-down and backwards apostrophe, because that was how nineteenth century printers rendered a lower-case superscript "c," which was itself an abbreviation for "Mc" or "Mac." Michael G. Collins, M'Culloch and the Turned Comma, 12 Green BAG 2D 265, 266 (2009). The second "c" at the end of the name was a misspelling in the court records; apparently, the correct spelling of the party's name was actually "McCulloh" (without the final "c"). MARK R. KILlEENBECK, M'CULLOCH V. MARYLAND: SECURING A NATION 90 (2006).

16 Robert G. MCClOSKEY, THE AMERICAN SUPREME COURT 66 (1960).

17 Keith E. Whittington, Political Foundations of Judicial Supremacy 111 (2007).

18 KILLENBECK, supra note 15 , at 7-8.

19 Michael J. Klarman, How Great Were the "Great" Marshall Court Decisions?, 87 VA. L. Rev. 1111,1128 \& $n .82$ (2001).

20 Daniel Walker Howe, What Hath God Wrought: the Transformation of America, $1815-1848$, at 144-45 (2007). 
casebook, usually introducing the topic of congressional power. ${ }^{21}$ As Gerard N. Magliocca has wryly observed, "Chief Justice Marshall cast such a powerful spell that M'Culloch has displaced the views of the Framers as the authoritative source on the scope of Congress's power." 22

The aggressive nationalism thesis lies at the heart of an ideology that regards Marshall as a "nation builder," a George Washington, Alexander Hamilton, or Henry Clay of the judicial branch. Constitutional law literature is filled with such references. Typical is Richard Fallon's assertion that "the Court led by John Marshall successfully implemented a nation-building agenda that subsequent generations have widely applauded." ${ }^{23}$ Such statements are typically left vague enough that their authors, if pressed, could retreat to a more modest and defensible claim that Marshall increased the prestige of the Supreme Court. But the insistent use of the term nation builder is also vague enough to imply that from his Chief Justice's seat, Marshall significantly contributed to the nation's institutions beyond the Court itself, including even its territories or infrastructure. It is in this context that McCulloch is said to be Marshall's signature nation-building achievement. ${ }^{24}$ Mainstream constitutional scholars thus seem to have

21 See, e.g., Willam C. Banks \& Rodney A. SMOlLa, Constitutional LaW: Structure AND RightS IN OUR FEDERAL SYSTEM 353, 355 (6th ed. 2010) (introducing chapter entitled "Federalism Limits on the Elected Branches and on the States"); DANIEL A. FARBER ET AL.,

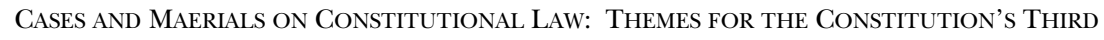
CENTURY 879, 881 (5th ed. 2013) (introducing chapter entitled "Federalism: Congressional Power and State Authority"); KathleEn M. Sullivan \& Gerald Gunther, Constitutional LaW 60, 63 (16th ed. 2007) (introducing chapter entitled "The Nation and the States in the Federal System"). McCulloch was included as a principal case in sixteen out of sixteen law school constitutional law casebooks surveyed for this Article, and the case was used to introduce the chapter on federalism or congressional power in fourteen of those. The other two still cite McCulloch prominently. See Research Memo on McCulloch in Casebooks (Jan. 9, 2015) (on file with author).

22 Magliocca, supra note 10, at 125.

23 Richard H. Fallon, Jr., How to Choose A Constitutional Theory, 87 CAL. L. REV. 535, 569 n.188 (1999); accord R. Kent NewMyer, John Marshall AND the Heroic Age of THE SuPREME COURT 302 (2001) (stating that Marshall led the Court "to help Congress help the people help themselves build a nation"); CASS R. SUNSTEIN, RADICALS IN ROBES: WHY EXTREME RIGHT-WING COURTS ARE WrONG FOR AMERICA 35 (2005) (describing "Marshall as a nation-building perfectionist"); Frankfurter, supra note 15, at 217 (“[Marshall] belongs among the main builders of our nation."); Louise Weinberg, Fear and Federalism, 23 OHIO N.U. L. REv. 1295, 1297 (1997) (noting "the nation-building spirit of John Marshall").

24 See, e.g., Frankfurter, supra note 15, at 217-19; Vicki C. Jackson, Federalism and the Court: Congress As the Audience?, 574 AnNAls AM. ACAD. POL. \& SOC. SCI. 145, 149 (2001) ("The nation-building, nationalizing impulses behind this Constitution were well expressed in McCulloch v. Maryland ....”); Keith E. Whittington, Judicial Review of Congress Before the Civil War, 97 GEO. L.J. 1257, 1329 (2009) (noting that antebellum Supreme Court interpreta- 
an investment in McCulloch that goes beyond its supposed contribution to constitutional law. Marshall, writes Kenneth Karst, "understood that he was not just creating doctrine but building a nation." ${ }^{25}$ In such statements lies an implicit, unexamined claim about the capacity of courts to contribute directly to the creation of national culture, wealth, and power.

A handful of historians of the Marshall Court have declined to go so far, and instead raise questions about an aggressive nationalist characterization of Marshall in general or McCulloch in particular. For example, William E. Nelson has argued Marshall was a "moderate judge" whose nationalism was "not... consistent." ${ }^{26}$ Instead, Marshall's nationalism was tempered by an eighteenth century consensusoriented judicial approach, in which judges would decide questions of government power either "by appealing to widely shared values" or, where those were unavailable, by treating the questions as "political" and deferring to legislative choices. ${ }^{27}$ Charles F. Hobson's brief but perceptive analysis of McCulloch posits that "Marshall's argument [did not] so much affirm a 'broad' (a term he did not use) construction of Congress's powers as reject the restrictive construction adopted by Maryland's counsel." ${ }^{28}$ Thus, "[a]s an expression of nationalism, ... McCulloch is not to be understood as a prescient anticipation of the modern liberal state." ${ }^{29}$ Other scholars have made general or passing remarks suggesting that McCulloch might have been more moderate than commonly supposed. ${ }^{30}$

But such cautionary notes have not made a dent in the aggressive nationalism thesis, probably for two reasons. First, given the decision's supposed importance in constitutional law, there is strikingly little historical scholarship focusing in detail on McCulloch. The two books by legal historians focusing on McCulloch are confirmatory of the aggressive nationalism thesis. ${ }^{31}$ Otherwise, treatments of $\mathrm{McCul}$ loch are limited to parts of book chapters or articles on Marshall or his "nationalism" decisions. Second, several important historians either

tions of the Constitution, including McCulloch, "contributed above all to the process of nation-building").

25 Kenneth L. KARST, Belonging to AMERICA: EQual Citizenship AND the Constitution 198 (1989).

26 William E. Nelson, The Eighteenth-Century Background of John Marshall's Constitutional Jurisprudence, 76 MiCH. L. REV. 893, 898, 933 (1978).

27 Id. at $901-02$

28 HoBSON, supra note 12, at 123.

$29 \quad I d$.

$30 \quad$ See infra note 453 and accompanying text.

31 See generally ELLIS, supra note 6; KILLENBECK, supra note 15. 
equivocate or backtrack from assertions that McCulloch was something less than aggressively nationalistic. G. Edward White observes that Marshall's was "not a nationalism in the modern sense of support for affirmative plenary federal regulatory power," but "can more accurately be described as a critique of reserved state sovereignty." ${ }^{32}$ But he elsewhere reads McCulloch to "g[i]ve to the federal government unlimited discretionary power within the scope of its enumerated powers," which makes "the significance of $\mathrm{McCul}$ loch... extraordinarily vast." ${ }^{33}$ Gerald Gunther and Kent Newmyer have likewise argued that McCulloch did not embrace an extreme form of nationalism. ${ }^{34}$ But they both proceed to exaggerate $\mathrm{McCul}$ loch's nationalistic impact on the crucial issue of Congress's power over internal improvements. Noting that the McCulloch decision carried potentially far-reaching implications for internal improvements- "McCulloch is the great case because it was a roads and canals case" ${ }^{35}$-Gunther argued, "[w]ith respect to the ongoing [internal improvements] debate, [McCulloch's] rationale gave impetus, not mere approval" to Henry Clay's American System package of nationalistic legislative proposals. ${ }^{36}$ Similarly, Newmyer reads McCulloch as laying the constitutional foundation for internal improvements, broadly asserting that "John Marshall's America" was characterized by

32 3-4 G. EdWard White, The Oliver Wendell Holmes Devise: The Marshall Court AND CUlTURAL CHANGE, 1815-1835, at 486 (1988).

33 G. EdWARd White, THE AMERICAN Judicial TrAdition 30 (3d ed. 2007). The original book was published in the mid-1970s, $i d$. at xxviii, but White has not changed this language in the recent edition, despite having published a much more nuanced account of Marshall's jurisprudence in the intervening years in the Holmes Devise. See supra text accompanying note 32 .

To similar effect, compare Balkin \& Levinson, supra note 2, at 1009 (suggesting McCulloch's importance as a nationalism case may have resulted from an historically retrofitted interpretation), with $i d$. at 973 (arguing McCulloch "established an expansive view of national power under the U.S. Constitution”).

34 See Gerald Gunther, Introduction to JOHN MARShall's Defense of MCCUlLoch V. MARYLAND 1, 20 (Gerald Gunther ed., 1969) (arguing that Marshall "did not view McCulloch as embracing extreme nationalism" and that he "opposed extreme formulations, excessively broad as well as unduly arrow, of the range of legitimate means"); R. Kent Newmyer, John Marshall, McCulloch v. Maryland, and the Southern States' Rights Tradition, 33 J. MARSHALL L. REV. 875, 877 (2000) (asserting that Marshall "is not only not consolidationist (as his critics maintained) but is far more nuanced and more attentive to the needs and practices of state government than is generally recognized").

35 Gunther, supra note 34, at 8; accord Mark A. Graber, James Buchanan as Savior? Judicial Power, Political Fragmentation, and the Failed 1831 Repeal of Section 25, 88 OR. L. REV. 95, 119 (2009) (asserting that the Marshall Court "pointedly inform[ed] James Monroe that the decision in McCulloch v. Maryland committed the Justices to sustaining all federally funded internal improvements"). 
"[a] national market-integrated by an efficient system of roads and canals and later railroads, guarded from the invasion of foreign goods by protective tariffs, and enhanced by a uniform currency and a national system of credit." ${ }^{37}$ But as I will argue below, McCulloch steered clear of all controversial aspects of the American System; while it did not affirmatively block, McCulloch gave neither impetus nor approval to such nationalist legislation. ${ }^{38}$

Not even revisionist scholars are immune from the aggressive nationalist reading of McCulloch. For example, Michael Klarman insightfully demonstrates that $M c$ Culloch did not have a great influence on subsequent antebellum constitutional questions; but he bases his argument in large part on the idea that Marshall was creating nationalist elbow room for a laggard Congress. ${ }^{39}$ According to Klarman, "[a]fter McCulloch, it was difficult to imagine a politically plausible congressional exercise of power that would exceed constitutional limitations, at least so long as Congress did not 'pass laws for the accomplishment of objects not intrusted to the [national] government' on a "pretext of executing its powers." "40 Klarman argues in essence that Marshall was more nationalistic than Congress: "nationalist decisions such as McCulloch and Gibbons" expressed "the Court's broad invitation [to Congress] to exercise national power." ${ }^{41}$ Klarman's revisionist argument about McCulloch's historical influences thus embraces the aggressive nationalism interpretation of the case. ${ }^{42}$

37 NEWMYER, supra note 23, at 301-02; accord Newmyer, supra note 34, at 880 (asserting that McCulloch "overrode Madison's arguments set forth in his veto of the Bonus Bill in 1816, which maintained that Congress could not authorize internal improvements without a constitutional amendment").

38 See infra Part III (discussing the internal improvements legislation that was relevant at the time of the decision).

39 This echoes an earlier assertion by Gunther that McCulloch "was a message ... to rally the sagging forces of nationalism and to combat the mounting constitutional self-doubts in Congress," because "[t]he 1819 consensus regarding the desirability and legitimacy of a national bank did not carry over to other national programs." Gunther, supra note 34, at 6.

40 Klarman, supra note 19, at 1126-27 (alterations in original) (quoting McCulloch, 17 U.S. (4 Wheat.) 316, 423 (1819)); see also id. at 1155 (asserting that the Marshall Court "embraced broad conceptions of national power"); $i d$. at 1160 (characterizing Marshall's "conception of national government power" as "latitudinarian").

41 Id. at 1144. To be sure, Klarman makes this point in the course of arguing that the invitations were ineffectual; but my point is that Klarman is mistaken in characterizing Marshall Court opinions as invitations. See infra note 75 and accompanying text (noting that the nationalist theory in McCulloch did not "imply ... an expansive interpretation of congressional powers").

42 Likewise, Howard Gillman argues, on the one hand and contrary to the received wisdom, that Marshall adopted a narrow reading of the Commerce Clause. See Howard Gillman, More on the Origins of the Fuller Court's Jurisprudence: Reexamining the Scope of Federal Power 
In sum, the power of the aggressive nationalism interpretation of McCulloch in our legal culture is so strong that it tends to dominate the views of legal historians and constitutional scholars alike.

\section{B. Aggressive versus Defensive Nationalism}

Several scholars, including adherents of the aggressive nationalism thesis, have distinguished between defensive and aggressive nationalism within Marshall's constitutional doctrines. ${ }^{43}$ In his 1936 lectures on the Commerce Clause, Justice Frankfurter distinguished between "Marshall's use of the commerce clause as an instrument of negation" and "the affirmative aspects of the commerce clause," through which the government might act "as a directing agent of social and economic policies." ${ }^{44}$ Justice Frankfurter did not discuss McCulloch in these Commerce Clause lectures, but his point nevertheless applies. More recently, White concludes that Marshall's "most nationalistic achievement" was his "erection of a theoretical justifica-

Over Commerce and Manufacturing in Nineteenth-Century Constitutional Law, 49 POL. REs. Q. 415, 423-24 (1996). Nevertheless, Gillman says that Marshall's "commitment to Hamiltonian political economy motivated him actively to tease out of the Constitution its more nationalistic features." Id. at 419. In fact, as will be seen, Marshall's embrace of Hamiltonian political economy was partial and half-hearted. See infra Part III (emphasizing the significance of what Marshall did not say in the McCulloch opinion when the nationalist arguments for internal improvements were obviously before him).

Mark Graber has built up an impressive body of work demonstrating that the nationalist principles attributed to Marshall Court decisions are alloyed by limitations and cagey political maneuvers, and had less impact on political and institutional developments than widely supposed. See, e.g., Graber, supra note 35, at 119 (arguing that the Marshall Court "mitigated potential tensions with Jeffersonian officials by pulling punches when political antagonisms were perceived as too intense”); Mark A. Graber, Establishing Judicial Review: Marbury and the Judicial Act of 1789, 38 TULSA L. REv. 609, 610 (2003) [hereinafter Graber, Establishing Judicial Review] (asserting that Marbury did not establish federal judicial review); Mark A. Graber, The Passive-Aggressive Virtues: Cohens v. Virginia and the Problematic Establishment of Judicial Power, 12 CONST. COMment. 67, 67-68 (1995) [hereinafter Graber, Passive-Aggressive Virtues] (arguing that the Marshall Court announced significant constitutional principles only when decisional outcomes would not antagonize hostile political forces). Graber does not focus in particular on McCulloch and does not observe that Marshall's compulsion to avoid antagonizing hostile political forces caused him to state McCulloch's principles themselves in moderate or cautious terms. Instead, Graber takes at face value the questionable assertion that the Marshall Court viewed McCulloch as having "committed" the Court to sustaining internal improvements legislation. Graber, supra note 35, at 119. I attempt to refute that view in this Article. See infra Part III.

43 See, e.g., Hobson, supra note 12, at 123 (characterizing McCulloch's nationalism as "negative or defensive").

44 Felix Frankfurter, The Commerce Clause Under Marshall, Taney and Waite 38-39 (1937). Note the restraint with which Frankfurter described both Marshall's nationalism and its causal connection to modern doctrine: Marshall "conveyed ... attitudes" that "eventually" "yielded ... support." Id. 
tion for [the Court's] own power to review actions of the states that potentially collided with the Constitution" ${ }^{45}$ rather than for "facilitat[ing] the development of national institutions or sustain[ing] regulatory policies" of the national government. ${ }^{46}$ Similarly, Newmyer argues that Marshall's nationalism consisted largely of defending the Court from political and legal attacks by Virginia states rights/compact theorists who, Marshall rightly believed, "wanted to redirect the entire course of American constitutional history" because they "looked to the Articles of Confederation, not the Constitution, as the true republican constitution." ${ }^{47}$ As Hobson sums up, Marshall's "negative or defensive" nationalism was "concerned primarily with preserving the union against powerful centrifugal tendencies that constantly threatened its dissolution." ${ }^{48}$

Legal scholars generally agree that most of the Marshall Court's great nationalism decisions are in the negative category. ${ }^{49}$ Dartmouth College v. Woodward, ${ }^{50}$ Sturges v. Crowninshield, ${ }^{51}$ and other Contracts Clause cases are in this category. Marshall's occasional dicta supportive of a dormant commerce clause is also in this category. ${ }^{52}$ These cases are nationalist, insofar as they assert the supremacy of the national Constitution over state law, but they do not expand the powers of the political branches of the Federal Government. The same is true for a second, closely related category, involving the assertion of the Supreme Court's appellate authority over state courts. Cohens $v$. Virginia, ${ }^{53}$ and Justice Joseph Story's opinion in Martin v. Hunter's Les$s e e^{54}$ are important cases in this category, as are parts of $M c C_{u l l o c h}^{55}$

45 WHITE, supra note 32 , at 594.

$46 \quad I d$. at 486.

$47 \quad$ Newmyer, supra note 34 , at 886.

48 Hobson, supra note 12, at 123; see id. at 115 ("[Marshall's] nationalist perspective inclined not forward to the nation state that emerged after the Civil War but backward to the 1787 idea of a government of the union whose objects were primarily ... to preserve the union against external invasion and internal turbulence.").

49 Professor White categorizes Marshall's "sovereignty and union" cases as falling into the categories of "jurisdiction of the federal courts" and "limitations ... on the sovereignty of the states." WHITE, supra note 32, at 485.

5017 U.S. (4 Wheat.) 518 (1819).

5117 U.S. (4 Wheat.) 122 (1819).

52 See, e.g., Gibbons v. Ogden, 22 U.S. (9 Wheat.) 1, 189 (1824) (noting the power to regulate interstate commerce "can never be exercised by the people themselves, but must be placed in the hands of agents, or lie dormant"); see also Willson v. Black-Bird Creek Marsh Co., 27 U.S. (2 Pet.) 245, 252 (1829) ("We do not think that the act empowering the Black Bird Creek Marsh Company to place a dam, across the creek, can, under the circumstances of the case, be considered as repugnant to the power to regulate commerce in its dormant state or as being in conflict with any law passed on the subject.").

5319 U.S. (6 Wheat.) 264 (1821).

5414 U.S. (1 Wheat.) 304 (1816). 
and Osborn v. Bank of the United States. ${ }^{56}$ While these decisions rely on Section 25 of the 1789 Judiciary Act, their focus is on judicial rather than congressional power.

McCulloch is not celebrated as a negative or judicial nationalism decision. It is thus important not to let our assessment of McCulloch's nationalism be unduly shaded by Marshall's negative nationalism in this other class of cases. To be sure, judicial review is inherently negative insofar as its direct impact stems from striking down laws, and rarely if ever affirmatively mandates legislative action. ${ }^{57}$ But while the Marshall Court could not have required the chartering of a national bank, or the building of a national road, it permitted the former and could have permitted the latter. The aggressive nationalism thesis views $M c$ Culloch as a kind of constitutional pre-approval letter for nationalist legislation of various kinds, including internal improvements. ${ }^{58}$ Such permission is rightly understood as constituting affirmative nationalism.

\section{Defensive Nationalism in McCulloch}

As is very familiar, the McCulloch opinion is divided into two main sections: the first, determining that Congress has the constitutional power to incorporate the Bank of the United States; and the second, holding that the state of Maryland lacks the power to tax the Bank.

Marshall's argument in McCulloch proceeds roughly as follows. The constitutionality of the Bank has been settled by longstanding legislative practice and acceptance by the political branches. ${ }^{59}$ The Court's analysis is in accord, and begins with the question of implied powers, because the power to incorporate a bank is not expressly

55 See, e.g., McCulloch v. Maryland, 17 U.S. (4 Wheat.) 316, 401 (1819) (“[B]y this tribunal alone can the decision be made. On the Supreme Court of the United States has the constitution of our country devolved this important duty.").

5622 (9 Wheat.) U.S. 738 (1824).

57 See WhitTington, supra note 17, at 43-44 ("Judicial review is more useful for hampering the expansion of government than for hampering the reduction of government, regardless of any policy disagreements between the Court and the elected branches.").

58 See supra notes 35-37 and accompanying text (characterizing the McCulloch decision as a commitment to sustaining all federally funded internal improvements).

59 See McCulloch, 17 U.S. (4 Wheat.) at 401 ("The principle now contested was introduced at a very early period of our history, has been recognized by many successive legislatures, and has been acted upon by the judicial department, in cases of peculiar delicacy, as a law of undoubted obligation."); see also BRAY HAMmOND, BANKS AND POLITICS IN AMERICA: FROM THE REVOLUTION TO THE CIVIL WAR 233 (1957) (describing Madison's eventual waiver of the question of constitutionality "as being precluded ... by repeated recognitions, under varied circumstances, of the validity of such an institution, in acts of the legislative, executive, and judicial branches of the government"). 
granted. ${ }^{60}$ Implied powers are not limited to those without which a granted power would be nugatory; rather, Congress must have discretion to choose among any means convenient or well adapted to implementing the granted power. ${ }^{61}$ Reading the Constitution in the narrower sense would undermine its adaptability to unforeseen crises in affairs and its ability to endure over time. ${ }^{62}$ The Necessary and Proper Clause is consistent with this view of implied powers, and was not intended by the Framers to narrow the granted powers, but to confirm the existence of implied powers. The Bank is constitutional because "it is a convenient, a useful, and essential instrument" in conducting the national government's "fiscal operations."

Having determined that the Bank is constitutional, Marshall considers whether Maryland can tax it. The question must be analyzed against the backdrop of federal supremacy, whose essence is to remove all obstacles to Federal Government action within its sphere. Taxation is a potential obstacle: it is essentially a power to regulate and even destroy what is taxed, and it is a power limited only by the political wishes of its constituents. ${ }^{64}$ States' sovereign power of taxation extends only to powers that can be conferred by the state's constituents, which does not include a power over the national government. $^{65}$ Therefore, states cannot tax operations of the general government, just as a part cannot control the whole. ${ }^{66}$

In evaluating the aggressiveness of McCulloch's nationalism, we should start by filtering out three sets of themes and issues whose nationalism is best characterized as defensive-and therefore not truly supportive of the aggressive nationalism thesis. First, McCulloch lays out Marshall's famous discussion of nationalist versus compact theory. Second, McCulloch discusses federal supremacy and holds that federal operations are immune from state taxation. Third, McCulloch is noted for what we might call Marshall's constitutionalism, a catchall that includes his various general statements about the nature of the Constitution and its interpretation.

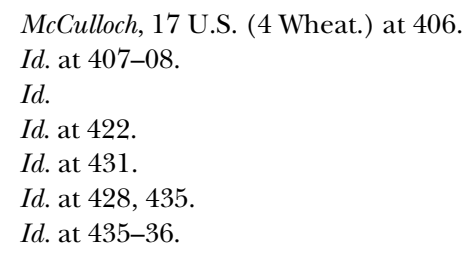




\section{Nationalist versus Compact Theory}

Marshall begins the Court's constitutional analysis by explicating what has become known as his nationalist theory of the United States Constitution, rejecting the so-called "compact theory." The government of the United States "proceeds directly from the people" rather than from a compact of sovereign States. ${ }^{67}$ The people met in state conventions as a convenience but that did not make the state conventions into the equivalent of sovereign state legislatures. ${ }^{68}$ On the contrary, the state legislatures assented to yielding the state's sovereignty to the constitutional scheme by "impli[cation] in calling a Convention, and thus submitting that instrument to the people." ${ }^{69}$ Marshall thus summarizes the argument from Federalist No. 37, that rather than reconstituting a league in which sovereign states yield bits of their sovereignty, the Constitution emanates directly from the people, thereby creating a government whose "powers are granted by them, and are to be exercised directly on them, and for their benefit." ${ }^{70}$

Marshall's elaboration of nationalist theory and rejection of compact theory was defensive in nature and motivation. He raised the issue because "counsel for the State of Maryland have deemed it of some importance, in the construction of the Constitution, to consider that instrument not as emanating from the people, but as the act of sovereign and independent States." ${ }^{, 11}$ In fact, Maryland counsel Luther Martin's oral argument to the Court was an extended antifederalist harangue, arguing that the Constitution, as a compact of

$67 \quad I d$. at 403.

$68 I d$. at $403-04$

69 Id. at 404.

70 Id. at 404-05; see also THE FEderalist No. 37, at 227 (James Madison) (Clinton Rossiter ed., 1961) ("The genius of republican liberty seems to demand ... that all power should be derived from the people.").

71 McCulloch, 17 U.S. (4 Wheat.) at 402 . Indeed, Marshall concedes that there is no tight logical connection between these theoretical arguments and implied powers: "The government of the Union, then, (whatever may be the influence of this fact on the case,) is, emphatically, and truly, a government of the people." Id. at 404-05 (emphasis added). Nor do the supremacy of federal law and the immunity of federal instrumentalities from state taxation logically depend on a rejection of compact theory. On the contrary, a union that was a compact of states could logically and naturally provide that the general government would be immune from state taxes and state control, and that its laws would trump those of an individual member. On the other hand, the supremacy and taxation arguments are theoretically stronger on a representation basis. It is not wholly unreasonable to theorize that states forming a compact or "league" might be said to count upon one another to behave collegially, and that an implied remedy where collegiality breaks down is to withdraw from the compact. Marshall's representation theory operates on the basis of hard democratic accountability, rather than comity, and implies the lack of one state's power to change its relation to the Union without the consent of all the people. 
the states, had to be strictly construed, with a heavy presumption against implied powers. ${ }^{72}$ As Newmyer and other scholars have told us, Marshall was deeply concerned to contest these attacks on the Constitution from anti-federalist extremists. ${ }^{73}$

But we have to be careful about over-attributing aggressive nationalism to Marshall as a spillover from the vehemence of his battles with anti-federalists. There is a difference between pushing forward the front lines of congressional regulatory power, and putting down guerilla uprisings far in the rear. It is far from clear whether rabid antifederalist critics in 1819 posed a significant threat to national institutions, Marshall's anxieties notwithstanding. ${ }^{74}$ Such arguments would re-emerge, but much later: nullification, not to say secession, was more than a decade away.

More to the point, while the nationalist theory in McCulloch might well have rebutted a compact-theory-based argument for strict construction, it did not necessarily imply the opposite-an expansive interpretation of congressional powers. ${ }^{75}$ To see the distinction between strong unionism and a belief in expansive national power, one need look no farther than the presidency of Andrew Jackson. His decisive reaction to put down the South Carolina nullifiers during the 1832-1833 nullification crisis was strongly unionist, yet he was an iconic advocate of limited national legislative power.

72 WHITE, supra note 32, at 238-39. This was not the first nor the last time Marshall would hear this argument-it would be flung against McCulloch in the Amphictyon and Hampden newspaper essays in the spring and summer of 1819 and urged on the Court again in Gibbons v. Ogden. For a collection of these essays and Marshall's defense, see JOHN MARSHALL'S DEFENSE OF MCCULLOCH V. MARYLAND (Gerald Gunther ed., 1969) [hereinafter MARSHALL'S DEFENSE].

73 See supra notes 47-48 and accompanying text (explaining that Marshall's nationalism was against external threats and internal turbulence); see, e.g., EDWARD S. CORWIN, JOHN MARSHALl AND THE CONSTITUTION 145 (1919) (explaining that Marshall saw himself as the "official custodian" of nationalist constitutional principles "in face of the rising tide of State Rights").

74 According to Sean Wilentz, Marshall critics such as John Taylor of Caroline, represented "a voice from the past, reflecting the deepening anxieties of the old Chesapeake Tidewater planter elite." SEAN WilentZ, The Rise of AMERican Democracy: JefFErson to LINCOLN 214 (2005).

75 See WHITE, supra note 32, at 486 (arguing that the kind of "nationalism" present did not include "support for affirmative plenary federal regulatory power."); Newmyer, supra note 34, at 898-901 (noting that the McCulloch decision left "an extensive body of promotive and regulatory economic legislation" "largely untouched"). 


\section{Taxation and Supremacy}

Many exponents of the aggressive nationalism thesis claim to draw support from Marshall's taxation and supremacy arguments. ${ }^{76}$ But these elements of McCulloch are not what have inspired subsequent generations to canonize the case as having "set forth" a "conception of the nation," in Justice Frankfurter's words. ${ }^{77}$ Simply put, we do not celebrate McCulloch either as "the Great Intergovernmental Tax Immunity case," or as "the First Great Preemption Case." Undoubtedly, these points are doctrinally important, ${ }^{78}$ and they provide plenty of nationalist atmospherics. But they represent quintessentially defensive nationalism, protecting the operation of federal laws and instrumentalities from state interference.

After rejecting compact theory, Marshall's opinion introduces "the question respecting the extent of the powers actually granted" to Congress. ${ }^{79}$ In the paragraph immediately following, Marshall grandly asserts that " $[\mathrm{i}] \mathrm{n}$ discussing these questions, the conflicting powers of the general and State governments must be brought into view, and the supremacy of their respective laws, when they are in opposition, must be settled." He then elaborates the supremacy principle. The United States government

[i]s the government of all; its powers are delegated by all; it represents all, and acts for all. Though any one State may be willing to control its operations, no State is willing to allow others to control them. The nation, on those subjects on which it can act, must necessarily bind its component parts.

The supremacy principle "is not left to mere reason: the people have, in express terms, decided it," by including the Supremacy Clause in the Constitution. ${ }^{82}$ Having established this point, Marshall begins his extended discussion of implied powers.

76 See, e.g., CoRWIN, supra note 73, at 144-45 (espousing the supremacy of national power over state power).

77 Frankfurter, supra note 15, at 219.

78 See, e.g., Egelhoff v. Egelhoff, 532 US 141, 160 (2001) (Breyer, J., dissenting) (stating that the preemption doctrine is "the true test of federalis[m] principle[s]"); Garrick B. Pursley, Preemption in Congress, 71 Ohio St. L.J. 511, 513 (2010) (" $[\mathrm{P}]$ reemption may be the most important issue for modern federalism theory ....").

79 McCulloch v. Maryland, 17 U.S. (4 Wheat.) 316, 405 (1819).

$80 \quad I d$.

81 Id.; see also CHARLES L. BLACK, JR., STRUCTURE AND RELATIONSHIP IN CONSTITUTIONAL LAW 14-15 (1969) ("Marshall's reasoning ... is, as I read it, essentially structural. It has to do in great part with what he conceives to be the warranted relational properties between the national government and the government of the states, with the structural corollaries of national supremacy—and, at some point, of the mode of formation of the Union."). 
This juxtaposition of the supremacy principle and implied powers might create the (mis)impression that affirming the supremacy of national laws is the same as broadening the reach of national legislative jurisdiction. But the two are plainly not the same: one could hold strict constructionist views about the breadth of national power while still maintaining that national laws, within their narrow sphere, are supreme. Again, Andrew Jackson's position during the nullification crisis illustrates this point. Marshall makes the same point in McCulloch's first Supremacy Clause passage by twice asserting "that the government of the Union, though limited in its powers, is supreme within its sphere of action." ${ }^{33}$

Once he turns to the discussion of implied powers just after this, Marshall puts the question of supremacy aside, picking up the supremacy thread again only in part II of the opinion, when discussing whether Maryland can tax the Bank. And the entire thrust of this part of the opinion is not to assert a principle expanding national power, but rather of preserving it from control and obstruction by the states. Marshall argues that "[i]t is of the very essence of supremacy to remove all obstacles to its action within its own sphere, and so to modify every power vested in subordinate governments, as to exempt its own operations from their influence." ${ }^{84}$ The operations and instrumentalities of the national government are the act of the whole people, subject to the control of the whole people. ${ }^{85}$ For a state to control national operations or instrumentalities violates the fundamental principle of democratic representation: it is the assertion by the people of one state of a right to control the people outside their state. ${ }^{86}$ Since taxation is a sovereign regulatory power, an incident of control, state taxation of a federal instrumentality is subject to the same principle. ${ }^{87}$ When Marshall says "the power to tax involves the power to destroy," he means two things that sometimes get lost in the aphoristic smoke of that pithy phrase. ${ }^{88}$ First, taxation is a form of control. Second, as a general matter, there is no constitutional check on the degree of taxation other than accountability to the electorate. "[W]hen a State taxes the operations of the government of the United States, it acts upon institutions created, not by their own constitu-

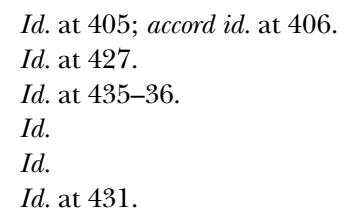


ents, but by people over whom they claim no control." ${ }^{19}$ The structure of the Constitution is largely designed to prohibit this sort of state opportunism and (in modern economic terms) cost externalization onto other states. In sum, Marshall's supremacy and taxation discussion aims fixedly on defending the constitutional union from attack by self-interested states.

The taxation and supremacy discussions fail to make McCulloch the great case in large part because these principles were defensively, rather than aggressively, nationalistic. Furthermore, and related, these points were unremarkable and unexceptionable. As William Nelson puts it, these discussions were "not [the] 'broad constitutional views' of an 'ardent nationalist" because " $[\mathrm{t}]$ he Supremacy Clause... mandated the supremacy of federal law over conflicting state law ... as clearly as any legal text requires a specific result." ${ }^{90}$ Nor were Marshall's views on federal supremacy and immunity from state taxation seriously contested outside the courtroom. After the decision was issued leading critics of McCulloch's nationalist constitutional theory and implied powers analysis agreed with Marshall's taxation and supremacy analyses, expressly conceding that the Bank, if constitutional, could not be taxed by Maryland. ${ }^{91}$ In later years, the Taney Court treated McCulloch as authoritative on the taxation point, even as it ignored McCulloch's implied powers holding. ${ }^{92}$ And while the Taney Court did not cite McCulloch on supremacy, its Supremacy Clause rulings were as aggressive, if not more so, than McCulloch. ${ }^{93}$ In other words, Marshall's nationalism on the tax and supremacy issues merely articulated an existing constitutional consensus acceptable to Republicans in 1819 and mainstream Jacksonians up to the secession crisis. These holdings thus provide exceedingly thin justification for the aggressive nationalism interpretation of McCulloch.

$89 \quad I d$. at 435

90 See Nelson, supra note 26, at 896 (citations omitted).

91 A Virginian's 'Amphictyon' Essays, RICHMOND ENQUIRER, April 2, 1819, reprinted in MARSHALL'S DEFENSE, supra note 72, at 76.

92 See New York ex rel. Bank of Commerce v. Comm'rs of Taxes, 67 U.S. (2 Black) 620, 63233 (1863) (applying McCulloch to strike down state tax on federal bonds); Dobbins v. Comm'rs of Erie Cnty. 41 U.S. (16 Pet.) 435, 449 (1842) (applying McCulloch to strike down state tax on federal revenue officer). For an argument that the Taney Court, led by Chief Justice Roger Taney, would have overruled McCulloch on the Bank and implied power issues had the opportunity arisen, see Magliocca, supra note 10, at 133.

93 See, e.g., Abelman v. Booth, 62 U.S. (12 How.) 506, 517-18 (1859) (holding that that Supremacy Clause does not allow the Supreme Court of Wisconsin to issue a writ of habeas corpus); Prigg v. Pennsylvania, 41 U.S. (16 Pet.) 539, 673-74 (1842) (holding that Pennsylvania's law prohibiting the extradition of blacks violated the Fugitive Slave Law of 1793 as applied by the Supremacy Clause). 


\section{Constitutional Interpretation}

McCulloch is filled with phrases and passages, including many favorites, that create at least an atmosphere consistent with the aggressive nationalism interpretation. The most important and best known of these are: "it is a constitution we are expounding" " and "a constitution intended to endure for ages to come." ${ }^{95}$ Justice Frankfurter called the first quote "the single most important utterance in the literature of constitutional law-most important because most comprehensive and comprehending." "96 Edward Corwin crystallized the second point into one of the six "tenets of nationalism" bestowed on posterity by Marshall. ${ }^{97}$ The first passage tells us that the existence of implied powers is the necessary implication of a constitution, which cannot specify the legislative means, such as bank charters, that may be used to promote its larger purposes. The second passage tells us that the phrase "necessary and proper" confirms, and does not restrict the general existence of implied powers; moreover, the idea of implied powers itself implies a breadth of legislative discretion over the choice of means so that the Constitution can endure over time and through unforeseen crises.

94 McCulloch, 17 U.S. (4 Wheat.) at 407 (emphasis omitted). The full passage states:

There is no phrase in the instrument which, like the articles of confederation, excludes incidental or implied powers; and which requires that every thing granted shall be expressly and minutely described .... A constitution, to contain an accurate detail of all the subdivisions of which its great powers will admit, and of all the means by which they may be carried into execution, would partake of the prolixity of a legal code, and could scarcely be embraced by the human mind. It would probably never be understood by the public. Its nature, therefore, requires, that only its great outlines should be marked, its important objects designated, and the minor ingredients which compose those objects be deduced from the nature of the objects themselves. That this idea was entertained by the framers of the American constitution, is not only to be inferred from the nature of the instrument, but from the language. Why else were some of the limitations, found in the ninth section of the 1st article, introduced? It is also, in some degree, warranted by their having omitted to use any restrictive term which might prevent its receiving a fair and just interpretation. In considering this question, then, we must never forget, that it is a constitution we are expounding.

Id. at $406-07$.

$95 \quad I d$. at 415 . The full passage reads:

This could not be done by confiding the choice of means to such narrow limits as not to leave it in the power of Congress to adopt any which might be appropriate, and which were conducive to the end. This provision is made in a constitution intended to endure for ages to come, and, consequently, to be adapted to the various crises of human affairs. To have prescribed the means by which government should, in all future time, execute its powers, would have been to change, entirely, the character of Id. the instrument, and give it the properties of a legal code.

96 Frankfurter, supra note 15, at 219.

97 CORWIN, supra note 73 , at 144-45. 
Thus, despite the grandeur of Marshall's phrasing, we have to keep our heads and remember that Marshall is making a fairly specific point: implied powers exist, giving Congress discretion to choose among a wide range of means to execute the government's enumerated powers. ${ }^{98}$ This tells us that Marshall's approach to constitutional interpretation is only as nationalistic as the implied powers doctrine it supports.

\section{McCulloch's “Aggressive” Nationalism}

The several above-discussed features of McCulloch that are taken as demonstrating Marshall's nationalism do not succeed in proving his "aggressive nationalism" - a broad assertion of the scope of federal power. Marshall's assertion of federal supremacy and tax immunity were a straightforward application of the Supremacy Clause, and not notably aggressive. His theoretical rejection of compact theory in favor of nationalist constitutional theory, together with his rejection of a general principle of narrow construction of federal powers, were refutations of extreme antifederalist positions that did not necessarily imply far-reaching nationalist ones. And Marshall's broad abstractions about constitutional interpretation likewise beg the question of whether or how much to construe congressional powers expansively.

Thus, the true test of McCulloch's "aggressive" nationalism calls on us to focus on the doctrine of implied powers and their relationship to enumerated powers. Does giving wide latitude to implied powers expand the powers of Congress if the enumerated powers are not construed broadly? If not, does McCulloch's articulation of the doctrine of implied powers, its application to the specific question of the Bank, or any supporting dicta in the opinion, generate an expansive interpretation of any enumerated power? In examining those questions, we should ask whether McCulloch affirmatively demonstrates, in Gillman's words, "a commitment to Hamiltonian political economy." ${ }^{99}$ Did it affirmatively promote, as Newmyer asserts, a national market or a national power to control the currency and the money supply? ${ }^{100}$ Did McCulloch, as Gunther claims, "g[i]ve impetus, not mere approval" to internal improvements legislation, and was " $\mathrm{McCul}$ -

98 Cf. Hobson, supra note 12, at 119 ("By this remark, [Marshall] meant only that the Constitution should not be read as a detailed blueprint for governing; it did not signify approval of the idea of an evolving Constitution.").

99 Gillman, supra note 42 , at 419 n.4.

100 NEWMYER, supra note 23, at 301-02. 
loch ... the great case because it was a roads and canals case" ${ }^{101}$ In other words, does McCulloch support a congressional power to build a road?

\section{MCCULLOCH'S CONTEXT: THE BANK CONTROVERSY AND THE MONEY SUPPLY}

The decision to uphold the Bank's constitutionality would not have seemed aggressively nationalistic in Chief Justice John Marshall's day. "To assert in 1819 that Congress had the power to establish a national bank was to validate an existing consensus, not to break new ground." ${ }^{102}$ The opportunity presented to make nationalist doctrine would largely consist in how the Court justified the Bank's constitutionality-by construing one or more congressional powers broadly.

The McCulloch decision was one episode in a long-running controversy over a national bank that began in 1790 and continued long after McCulloch was decided in $1819 .{ }^{103}$ Nearly thirty years of debates over a national bank preceding McCulloch created a rich record of factual, policy, and constitutional arguments that supported not only the Bank's constitutionality, but also potentially broad interpretations of several congressional powers. The history further demonstrates that one did not need to have the intellect of the great federalist mastermind Hamilton to appreciate the arguments: they were widely available and intellectually accessible in 1791, let alone 1819. Marshall was well aware of this history, having studied the 1790-1791 documents in preparing his biography of George Washington. And

101 Gunther, supra note 34, at 7-8. Cf. WHITE, supra note 32, at 542 (asserting that contemporary observers viewed McCulloch as "especially important" because they "regarded it as a kind of advisory opinion for two other issues of even greater potential importance, the constitutionality of federally sponsored internal improvements projects and the constitutionality of federal slavery legislation").

102 Gunther, supra note 34, at 4; accord Hobson, supra note 12, at 117 ("Under the circumstances, a holding that Congress had no authority to charter a bank would have been extraordinary."); HOWE, supra note 20, at 145 (arguing that "the constitutionality of the Bank did not in itself surprise observers, since the Republican Party had come around to endorsing it in 1816"); Klarman, supra note 19, at 1128-29, 1160 (arguing that McCulloch's "holding that the Necessary and Proper Clause empowered Congress to charter a bank was quite unexceptionable in 1819"); see also text accompanying notes 180-85 (detailing Jeffersonian Republican support for a second bank).

103 The history of the National Bank was itself an element in a larger constitutional struggle over the question of federal control over national currency and monetary policy. Other major episodes included President Andrew Jackson's Bank Veto; the 1862 National Bank Act; the Legal Tender Cases of 1870, 1871, and 1884; the Federal Reserve Act of 1913; and the 1934 Gold Clause Cases. The fundamental questions of congressional control were not fully settled for 150 years after the founding of the republic. See generally JAMES WiLLARD HuRst, A LEgAL History OF MONEY IN THE United STATES, 1774-1970 (1973). 
any more recently developed constitutional arguments were ably presented to him at the McCulloch oral argument.

It is therefore striking that, as we shall see, Marshall disregarded virtually all of the arguments available to him for upholding the Second Bank on a broad ground. In particular, Marshall declined to address arguments that the national government had an implied power to impose a uniform national currency, and that control over the currency by a central bank would facilitate interstate commerce. The $M c$ Culloch opinion refrains from giving a broad interpretation to any identifiable enumerated power.

\section{A. Constitutional Foundations}

McCulloch is a famous case in large part because the U.S. Constitution does not expressly grant Congress the power to charter a bank. But McCulloch tells us precious little about the degree to which the Constitution does expressly deal with national authority over monetary and financial issues that go to the heart of banking. The American economy under the Articles of Confederation was, according to financial historian Bray Hammond, a whole that "was weaker than its parts, which followed their thirteen, sovereign, jealous, and selfish courses to the rapid deterioration of common interests."104 Commerce was hampered both by discriminatory taxation and the lack of a uniform currency. ${ }^{105}$ Merchants in states lacking ports for foreign commerce had to pay tribute to those that did, through which their foreign imports had to pass. ${ }^{106}$ As President James Madison put it, "New Jersey, placed between Philadelphia and New York, was likened to a cask tapped at both ends; and North Carolina, between Virginia and South Carolina, to a patient bleeding at both arms." ${ }^{107}$ Further, each state had its own monetary system and resident-friendly laws: "[a] merchant in Massachusetts or Connecticut, for example, was helpless in collecting amounts due him from Rhode Island, because Rhode Island money though depreciated was legal tender, and Rhode Island in her courts and laws sought to protect her citizens from oppression by 'foreigners." 108 Though this state of affairs was of far greater concern to merchants than to the self-sufficient agrarians who composed the majority of the population, delegates at the Con-

\footnotetext{
104 HAMMOND, supra note 59, at 89.

$105 \quad I d$.

106 Id.

107 Id.

108 Id. at 90.
} 
stitutional Convention placed a high priority on addressing commercial issues in the new Constitution: "[i] t was the plight of commerce that thrust the reluctant states into a more perfect union."109

To address these problems, the new Constitution prohibited states from laying tonnage duties and from using import and export taxes as a source of revenue, ${ }^{110}$ as well as generally authorizing Congress to regulate foreign and interstate commerce. ${ }^{111}$ Beyond these clauses are several provisions dealing with finance. Congress was authorized to coin money and regulate its value; to punish counterfeiting; and to borrow money on the credit of the government. ${ }^{112}$ States were forbidden to "coin Money; emit Bills of Credit; [or] make any Thing but gold and silver Coin a Tender in Payment of Debts." congressional power to determine the value of coin, which implicitly denied that power to the states, was a continuation of policy established under the Articles of Confederation. ${ }^{14}$ But the other prohibitions on state issues of money, either as coin, paper or negotiable debt instruments, were new. Taking these clauses together, according to Willard Hurst, " $\mathrm{t}$ ] he clearest policy set in the federal Constitution showed strong distrust of allowing state legislatures to set moneysupply policy ... [and] determined that ultimate control of the money supply should be a matter of national policy." 115

These provisions left certain matters ambiguous. While states were clearly prohibited from issuing money from their own treasuries or mints, or from recognizing banknotes of state chartered banks as legal tender for private debts, ${ }^{116}$ the affirmative money powers of Congress were not fully specified. Could Congress issue paper money? And if so, could it make that paper money legal tender? The latter question would not be fully resolved for a century. But the power to issue paper money seemed to be implied: the express prohibition on state bills of credit combined with an absence of a like prohibition on Congress, an affirmative authorization to borrow money, and an

109
Id. at 91 .

U.S. CONST. art. I, $\S 10$, cl. 3 (prohibiting tonnage duties); U.S. CONST. art. I, § 10, cl. 2 (limiting import and export duties to only cover the cost of inspection of the goods, with any overage payable to the national treasury).

U.S. CONST. art. I, § 8 .

CONST. art. I, $\S 10$, cl. 1 .

HuRST, supra note 103 , at 8 .

Id.

The Supreme Court eventually recognized that states' sovereign powers authorized them to accept payment of state taxes in whatever form of money- or for that matter in kindthey chose. Lane County v. Oregon, 74 U.S. (7 Wall.) 71, 77 (1868). 
implied authorization to issue "securities" (in the counterfeiting clause) $)^{117}$ all suggest that Congress was authorized to put treasury notes into circulation as currency.

\section{B. The First Bank and Hamiltonian Political Economy}

Historically minded exponents of the aggressive nationalism thesis suggest that Marshall used the McCulloch case as an opportunity to embrace "Hamiltonian political economy." To be sure, Marshall's opinion relied heavily on the constitutional history of the First Bank of the United States (1791-1811). "An exposition of the constitution, deliberately established by legislative acts, on the faith of which an immense property has been advanced, ought not to be lightly disregarded," Marshall wrote. ${ }^{118}$ He went on to allude to the debates over the Bank's constitutionality:

After being resisted, first in the fair and open field of debate, and afterwards in the executive cabinet, with as much persevering talent as any measure has ever experienced, and being supported by arguments which convinced minds as pure and as intelligent as this country can boast, it became a law. ${ }^{119}$

The history and debates surrounding the First Bank are important because they illustrate the constitutional underpinnings of Hamiltonian political economy, arguments that were well known to Marshall. We can then examine to what extent these arguments found their way into the McCulloch opinion.

\section{Hamilton's Bank Report}

Alexander Hamilton, the nation's first Secretary of the Treasury, set out to address these issues by offering the First Congress a comprehensive set of proposals to rationalize the nation's finances and promote domestic industry. After the First Congress passed a bill adopting the recommendations in Hamilton's First Report on the Public Credit to assume and refinance state revolutionary war debts, on December 14, 1790, it received Hamilton's Second Report on the Further Provision Necessary for Establishing Public Credit, also known as the Report on a National Bank ("Bank Report"). ${ }^{120}$

\footnotetext{
117 See U.S. CONST. art. I, $\S 8$, cl. 6 (granting Congress the power to punish counterfeiting "the Securities and current Coin of the United States").

118 McCulloch v. Maryland, 17 U.S. (4 Wheat.) 316, 401 (1819).

119 Id. at 402.

1207 AleXANDer Hamilton, Final Version of the Second Report on the Further Provision Necessary for Establishing Public Credit (Report on a National Bank), Dec. 13, 1790, reprinted in THE
} 
Though a policy paper in nature and intent, the Bank Report is highly relevant to the underlying constitutional question. Arguments about implied powers are grounded in the factual and policy questions about how closely and well a proposed policy serves to execute a power expressly granted in the Constitution. In his Bank Report, Hamilton's policy arguments implicated several enumerated powers from which a constitutional power to charter a national bank could be implied.

Hamilton began by arguing that a national bank would be of service "not only in relation to the administration of the finances, but in the general system of the political economy." ${ }^{121}$ On the administrative side, a national bank would be able to give "pecuniary aids" to the government "especially in sudden emergencies" because they collect private capital and command credit far in excess of what is in their vaults. ${ }^{122}$ Further, a national bank would facilitate the payment of taxes: taxpayers can get loans to pay taxes, but more importantly, the Bank's notes increase the quantity of (nationally uniform) circulating medium in which to pay taxes. ${ }^{123}$ Without a national bank, "if there happen to be no private bills, at market, and there are no Bank notes, which have a currency in both ... coin must be remitted." ${ }^{124}$ Banks are also convenient instruments for the payment of public debts "at thirteen different places." ${ }^{125}$ Without bank-issued paper money, government payment of debts would require transporting gold and silver around the country to government creditors, with the result that "a considerable proportion of the specie of the country must always be suspended from circulation" as it is transported, at great risk, from place to place. $^{126}$ Banks can replace this cumbersome process with easily conveyed paper banknotes or even deposit credits. ${ }^{127}$

Additionally, as financial historian Bray Hammond summed up, Hamilton wanted to make the Bank "as powerful a credit agency as possible in the new American economy" to promote the nation's foreign and domestic commerce. ${ }^{128}$ In general, Hamilton argued, banks

PAPERS OF AlEXANDER HAMILTON 305, 350 (Harold C. Syrett \& Jacob E. Cooke eds., 1963); see also David P. Currie, The Constitution in Congress: The Federalist PERIOD, 1789-1801, at 78 (1997) (discussing Hamilton's report).

7 HAMILTON, supra note 120 , at 319.

Id. at 309

$I d$. at $309-10$.

Id. at 310 .

Id. at 322 .

Id.

Id. at 322-23.

HAMMOND, supra note 59 , at 139 . 
expand the money supply far in excess of "the actual quantum of their capital in Gold \& Silver" by circulating money equivalents in the form of banknotes or credits against depositor's accounts. ${ }^{129}$ Banknotes are redeemable in gold and silver specie, but due to the convenience of paper, the notes "are indefinitely suspended in circulation, from the confidence which each holder has, that he can at any moment turn them into gold and silver." ${ }^{130}$ Likewise deposit credits shift from bank to bank without note holders or depositors seeking to withdraw specie. ${ }^{131}$ Banks in this way "increase the active capital of a country" and thus "contribut[e] to enlarge the mass of industrious and commercial enterprise," thereby becoming "nurseries of national wealth." 132

A national bank was also useful commercially to control the money supply. Hamilton was aware that strict reliance on specie as currency could cause severe liquidity crises, dragging down commercial transactions and also creating extreme difficulties to the government in collection of taxes. ${ }^{133}$ Chronic undersupply of specie always creates pressure for paper money to come from somewhere, and fiscal crises put pressure on the government to print money. While the Constitution prohibited states, but not the Federal Government, from "paper emissions," government issuance of paper money is always "liable to abuse." ${ }^{\prime 34}$ Banks offer an advantage over government as a source of paper money: they will limit their issuance of notes to some fixed ratio of their gold and silver reserves, whereas the government is limited by mere good judgment, which will be hard pressed by the needs of the moment. ${ }^{135}$

Finally, Hamilton demonstrated the utility of relying on a privately chartered corporation instead of trying to conduct these functions directly through the U.S. Treasury. According to Hamilton, the Bank should be an essentially private, for-profit institution, for two related reasons. First, government could not be trusted to avoid overdrawing a public bank's resources to address "the temptations of momentary exigencies." ${ }^{136}$ Second, the confidence required for the Banks' notes

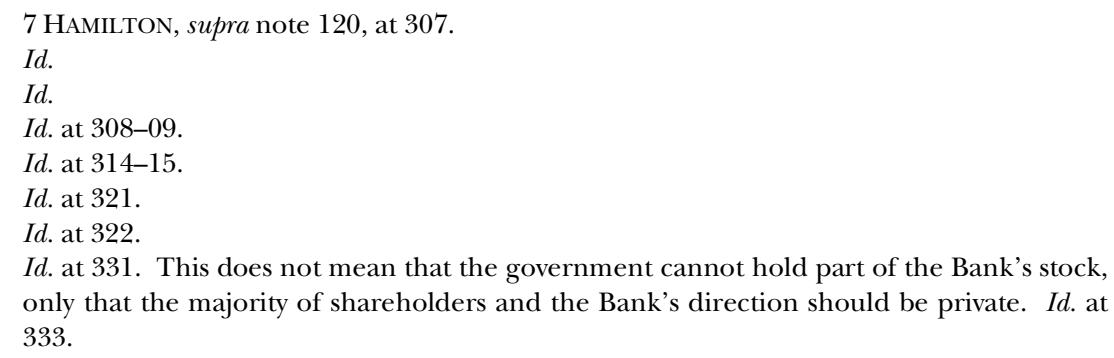


and credit to circulate without excessive demands for redemption in specie required that the Bank be directed "under the guidance of individual interest, not of public policy." ${ }^{137}$ This would also mean both that profits would have to return to the Bank's stockholders, and not go directly into the Treasury.

A Senate committee adopted Hamilton's recommendations and reported out a bill to incorporate a Bank of the United States. ${ }^{138}$ The proposal was immediately controversial. In the debates in the House, Hamilton's policy arguments were reframed in constitutional terms. Representatives Fisher Ames, Elbridge Gerry and Theodore Sedgwick of Massachusetts, and Elias Boudinot of New Jersey, took the lead for the Bank supporters. ${ }^{139}$ They readily acknowledged that incorporating a bank was a matter of powers implied from those enumerated. ${ }^{140}$ Sedgwick argued that "the constitution had expressly declared the ends of Legislation; but in almost every instance had left the means to the sober and honest discretion of the Legislature." ${ }^{141}$ Ames pointed to established congressional precedent for legislating on implied powers: from its first session, Congress had passed acts to build and operate lighthouses, tax ships, and regulate merchant seaman based on the idea that authority was implied by the commerce power. ${ }^{142}$ The power to charter a bank was implicit in the commerce, war, and borrowing powers, as well as the power to pay the debts of the United States. Commerce, he argued, is facilitated by banknotes, paying debts by more easily transferring money around the country, and borrowing large sums to wage war or finance other government needs was greatly facilitated by a national bank. ${ }^{143}$ Sedgwick added that Madison, a leader of the opposition to the Bank charter, had endorsed the idea of implied powers when advocating for the President's power to remove officers. ${ }^{144}$

Opponents, led by then-Congressman James Madison in the House, argued that the Constitution did not grant, and thus implicit-

137 Id. at 331 (alterations omitted). Marshall at least dimly understood this idea, because in Osborn, he insisted (rightly) that the Second Bank's ability to service the government's fiscal needs depended on its conducting ordinary, private banking operations that would give it commercial self-sufficiency. Osborn v. Bank of the U.S., 22 (9 Wheat.) U.S. 738, 766-67 (1824).

138 HAMMOND, supra note 59, at 114-15.

139 CURRIE, supra note 120 , at 78-79.

$140 \quad I d$. at 79.

141 Id. at 79 n.193 (quoting 2 ANNALS OF CONG. 1962 (1791) (statement of Rep. Sedgwick)).

142 Id. at 79.

143 Id.

$144 \quad I d$. 
ly withheld, authority from the national government to charter banks or any other corporations; and a national bank whose branches in various states would compete with state banks, would interfere with the rights of states to establish, or for that matter to prohibit, banks. ${ }^{145}$ (There were only four state banks in the country in 1791, but there would be twenty-nine by $1800 .{ }^{146}$ ) And of course, they argued for strict construction of implied powers as limited to those means "strictly necessary" to the various enumerated powers: since state banks could fulfill the national government's banking needs, a national bank was not strictly necessary. ${ }^{147}$

The Senate passed the bill on January 20, 1791 and on February 8, the House passed the bill by a wide margin, 39 to 20 , with most support coming from Northern States and most opposition from Southern States. ${ }^{148}$ The bill was submitted to President Washington, who took his full allotment of time to consider it, asking his Secretary of State Thomas Jefferson and his Attorney General Edmund Randolph to write opinions on its constitutionality. ${ }^{149}$ Both argued that the Bank Bill was unconstitutional and urged Washington to veto it. ${ }^{150}$ Washington then referred the matter to Hamilton for a response. ${ }^{151}$

\section{Hamilton's Opinion on Constitutionality}

With only a few days to go before Washington's reply to Congress was required by the Constitution's Presentment Clause, Hamilton produced a memorandum responding point by point to the written opinions of Randolph and Jefferson. Like Marshall thirty years later, Hamilton was well aware that, notwithstanding the "great importance of [the Bank] to the successful administration of" the U.S. Treasury, "the chief solicitude arises from a firm persuasion, that principles of [constitutional] construction like those espoused [by Jefferson and Randolph] would be fatal to the just \& indispensible authority of the

\footnotetext{
145 HAMmOND, supra note 59, at 115. Opponents also made non-constitutional arguments, to the effect that banks favored mercantile over agrarian interests and bred corruption. Id. at 116. On the corruption issue, it is noteworthy that thirty members of Congress were among the Bank's subscribers (initial stock purchasers). Id. at 123. While historically important, these arguments are tangential to the arguments in this Article.

146 Id. at 128, 144-45.

147 CURRIE, supra note 120 , at 79-80.

148 HAMMOND, supra note 59, at 116-17.

$149 \quad$ Id. at 117.

$150 \quad I d$.

151 Id. at $117-18$
} 
United States." ${ }^{152}$ Like Marshall, Hamilton also argued from legislative precedent. But whereas Marshall had the legislative precedent of the First Bank to argue from, Hamilton had to analogize to other exercises of implied powers to make a broader point against Jefferson's restrictive rule of construction:

Of this the act concerning light houses, beacons, buoys \& public piers, is a decisive example. This doubtless must be referred to the power of regulating trade, and is fairly relative to it. But it cannot be affirmed, that the exercise of that power, in this instance, was strictly necessary; or that the power itself would be nugatory without that of regulating establishments of this nature. ${ }^{153}$

In other words, the Commerce Clause implied a power to build and deploy navigation aids, even though such things were not strictly necessary to regulating interstate and foreign commerce. But Hamilton went beyond implied powers to argue for a broad approach to enumerated powers. The Commerce Clause precedent illustrated the "sound maxim of construction ... that the powers contained in a constitution of government, especially those which concern the general administration of the affairs of a country, its finances, trade, defence [etc.] ought to be construed liberally, in advancement of the public good." ${ }^{154}$ Randolph had argued that strict construction of the federal Constitution was warranted because there was more danger of error in interpreting limited grants of power than in implying general powers from state constitutions. ${ }^{155}$ But, Hamilton argued, "public exigencies" at the national level are more likely to be "of a far more critical kind." tion in practice," but a general rule of strict construction "would at once arrest the motions of the government."157

Addressing the specific question, Hamilton asserted that a national bank has an "immediate" relation to the powers to collect taxes and borrow money; a "more or less direct" relation to the powers "of regulating trade between the states" and "supporting and maintaining fleets and armies"; and fell "clearly, within" the authority to make "all needful rules and regulations concerning the property of the United

\footnotetext{
1528 Alexander Hamilton, Final Version of an Opinion on the Constitutionality of an Act to Establish a Bank, Feb. 23, 1791, reprinted in HAMILTON PAPERS 97 (Harold C. Syrett \& Jacob E. Cooke eds., 1965).

153 Id. at 104 (citations omitted) (emphasis omitted).

$154 I d$. at 105 (emphasis added).

$155 I d$. at $105 \&$ n. 12

156 Id. at 105

157 Id. at $105-06$.
} 
States." 158 A bank relates to the collection of taxes by "increasing" and "quickening" the circulation of currency, and by facilitating the payment of taxes with a convenient medium of payment-paper money, rather than only specie. ${ }^{159}$ The government has the right to determine the form of money it will accept in payment, including, for instance, Treasury bills. ${ }^{160}$ Since the government could issue its own tokens of credit to use in payment of taxes, why could it not create a bank to do so? ${ }^{161}$

Hamilton argued that foreseeable crises involving the taxation, borrowing, and war powers might be difficult or impossible to solve without a bank. Should economic conditions produce a drain of specie from the nation, the collection of taxes would be extremely difficult, and some sort of paper medium would have to be substituted for gold or silver. When the nation is facing a potential war, "[1]arge sums are wanted, on a sudden, to make the requisite preparations," but loans from individuals or small banks can be too slow or entirely unavailable. $^{162}$ If the government has the constitutional power to resort to a bank in this crisis situation, it has the power to do so before the crisis arises: "Anticipation is indispensible," and, what is more, "[c]ircumstances may affect the expediency of the measure, but they can neither add to, nor diminish its constitutionality." ${ }^{163}$ "The expediency of exercising a particular power, at a particular time, must indeed depend on circumstances; but the constitutional right of exercising it must be uniform and invariable-the same to day, as to morrow." $" 164$

The Bank was also implied from the Commerce Clause, having "a natural relation to the regulation of trade between the States." "Money is the very hinge on which commerce turns." " Scarcity of gold and silver coin becomes a drag on trade in the absence of bank credit and paper issues; a bank is thus "conducive to the creation of a convenient medium of exchange" to keep commerce going. ${ }^{167}$ Hamilton summarizes Jefferson as having argued that " $[\mathrm{t}] \mathrm{o}$ erect a bank" is to "create[] a subject of commerce," but not to regulate it, no dif-

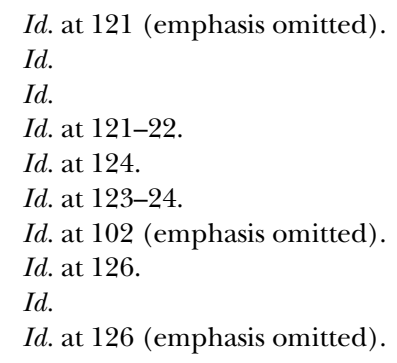


ferent from making a bushel of wheat or mining a dollar's worth of ore. ${ }^{168}$ But Jefferson's examples, Hamilton argued, dealt only with plainly local "details of buying and selling." ${ }^{169}$ The activities of a national bank would "be directed to those general political arrangements concerning trade on which [the nation's] aggregate interests depend," and "whose objects are to give encouragement to the enterprise of our own merchants, and to advance our navigation and manufactures." ${ }^{\prime 70}$ The Bank's activities are "to be regarded as a regulation of trade" by providing "facilities to circulation and a convenient medium of exchange and alienation."

Hamilton further supported his expansive interpretation of the term "regulate," by pointing to the Territorial Clause, which authorizes Congress "to dispose of and make all needful rules and regulations respecting the territories or property of the United States;" and "has been construed to mean a power to erect a government," which is a corporate body. ${ }^{172}$ Hamilton construed the commerce power as essentially parallel to that: the power to "regulate" commerce "is a power to make all needful rules and regulations concerning trade." 173 Thus, the power to regulate authorizes the creation of a public corporation; why not a public-private one? By analogy to the Territorial Clause, then, Congress can regulate commerce by chartering a corporation for that purpose, such as a bank or even a trading company (like the East India Company). And directly under the Territorial Clause, it can charter a corporation to manage the United States' "territories or property," the latter including the money in its Treasury, for which a bank corporation would be useful. ${ }^{174}$

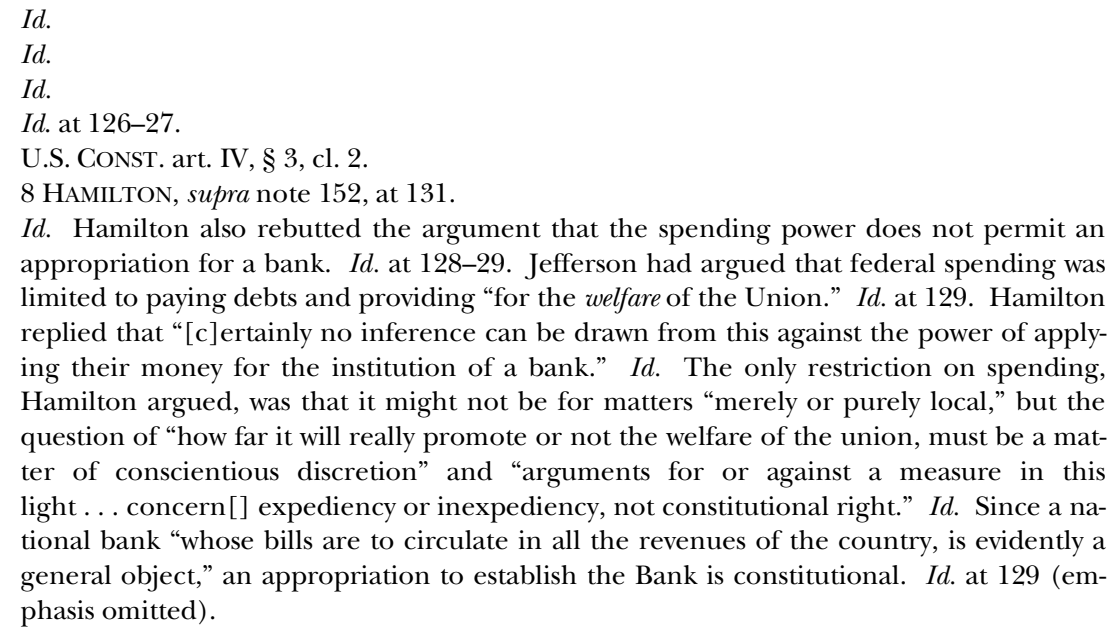
appropriation for a bank. Id. at 128-29. Jefferson had argued that federal spending was limited to paying debts and providing "for the welfare of the Union." Id. at 129. Hamilton replied that "[c]ertainly no inference can be drawn from this against the power of applying their money for the institution of a bank." Id. The only restriction on spending, Hamilton argued, was that it might not be for matters "merely or purely local," but the question of "how far it will really promote or not the welfare of the union, must be a matter of conscientious discretion" and "arguments for or against a measure in this light... concern[] expediency or inexpediency, not constitutional right." Id. Since a national bank "whose bills are to circulate in all the revenues of the country, is evidently a general object," an appropriation to establish the Bank is constitutional. Id. at 129 (emphasis omitted). 
As a capstone argument, Hamilton advanced a synergistic approach to interpreting congressional powers. Taking "an aggregate view of the constitution," Hamilton argued that the powers to tax and spend, to borrow money, to coin money and regulate foreign coin, and to make needful rules and regulations respecting government property combine to show " $[\mathrm{t}]$ hat it is the manifest design and scope of the constitution to vest in congress all the powers requisite to the effectual administration of the finances of the United States." ${ }^{175}$ A bank is "so usual as well as so important an instrument" to execute this aggregate power that a "strong presumption[]" is raised in favor of implying a power to create a bank. ${ }^{176}$ Furthermore, banks and corporations are a means implicitly residing within the sovereignty of all governments, as evidenced by the use of banks and trading companies by other nations. In this light, "[1]ittle less than a prohibitory clause can destroy the strong presumptions" supporting the power to create a bank. ${ }^{177}$

\section{Charter and Expiration}

Washington was convinced, and signed the Bank Bill into law on February 25, 1791. By most accounts the First Bank fulfilled its intended functions effectively over the next twenty years. Branches were opened in several cities beginning in spring of $1792 .{ }^{178}$ The Bank acted as fiscal agent of the Treasury, making payments of interest on public debt and salaries of government officials (including Jefferson), brokering sales of new issues of government securities, collecting taxes and customs duties, supplying gold bullion and foreign coins to the U.S. Mint, brokering foreign exchange, moderating the outflow of specie to foreign countries, providing a widespread and uniform circulating medium-its notes were legal tender for debts due the government-and serving as the principal depository of government funds. ${ }^{179}$ The initial opposition died down as Jeffersonians became reconciled to the Bank or saw its advantages. ${ }^{180}$ While Jefferson's personal dislike of the First Bank never diminished, he tempered this attitude as president by deferring to the views of his Treasury Secretary, Albert Gallatin, who was a great appreciator of the

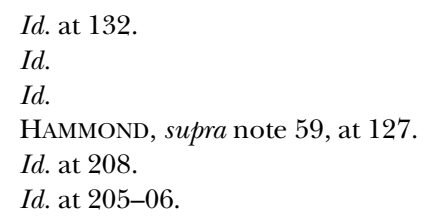


Bank's usefulness. Gallatin had persuaded Jefferson to sign legislation authorizing the Bank to establish a New Orleans branch office, notwithstanding the latter's continued constitutional doubts. ${ }^{181}$ Jefferson also signed a bill to punish the counterfeiting of the First Bank's notes. ${ }^{182}$

Nevertheless, with the First Bank's charter nearing its end as 1811 approached, it appeared that its "excellent record ... did it insufficient good politically." " been only three or four other banks in the United States, all chartered by states. In 1811, when the Bank's charter expired, there were ninety. Most of this explosion in state-chartered banking occurred after the Jeffersonian party came into power and only accelerated as the Federalist party disintegrated, reflecting a political shift in the party alignment of businessmen. This political shift resulted from a democratization of American business, as the nation's commercial center of gravity shifted from foreign commerce, dominated by oldline (Federalist-leaning) coastal merchants, to an increasingly diversified internal economy. The aristocratic circle of federalist merchants was overtaken by a new generation of businessmen whose interests and temperament would not have disposed them favorably toward a conservative monopolistic institution. "The success of the Republican party in retaining the loyalty of the older agrarians while it recruited among the newer entrepreneurial masses was possible... because equality of opportunity in business and the principle of laisser faire could be advocated with a Jeffersonian vocabulary." ${ }^{184}$ The profusion of new state banks could create more money and easy credit to meet the wants of these arriviste businessmen, and Jefferson himself embraced the idea "of making all the banks Republican." ${ }^{185}$

In this environment, the First Bank was destined to become a political target. Not only was it indelibly associated with the Federalists, but it tended to play a restraining role on state banks' business. By 1811, state banks were creating most of the credit for American businesses. State banks, along with their customers, would want to pay their federal taxes with state banknotes and checks written against their state bank deposits. The First Bank, as the agent for collection

$181 \quad I d$.

182 DAvid P. Currie, The Constitution in CONGRess: The JefFersonions, 1801-1829, at 250-51 (2001); HAMMOND, supra note 59, at 139, 205-08; HURST, supra note 103, at 7778.

183 HAMMOND, supra note 59, at 209.

$184 I d$. at 145-46 (emphasis omitted).

185 Id. at 146. 
of federal taxes, would thus inevitably become the creditor of these banks. By demanding that the state banknotes and credits be redeemed in specie, and thereby refusing to accept non-redeemable notes, the First Bank could and did impose controls on state banks' ability to create money and credit. ${ }^{186}$ The First Bank thus created a powerful restraint on inflationary paper issues, or the profligate suspension of specie payment, by undercapitalized state banks. While conservative state banks might appreciate this restraining, quasicentral banking function, "[t]he reckless and speculative bankers resented it." ${ }^{187}$

Congress opened debate on the Bank in January 1811. ${ }^{188}$ Proponents of re-chartering argued that the Bank's constitutionality was established by non-judicial precedent. ${ }^{189}$ A report to the Senate from Gallatin, who had been retained by President Madison as Treasury Secretary, pointed out that the Bank had been "for a number of years been acted upon or acquiesced in as if Constitutional by all the constituted authorities of the nation." 190 Significantly, when the argument got around to identifying the enumerated powers from which the Bank could be implied, Jeffersonian supporters of the re-charter tried to harmonize their pro-Bank views with their strict construction principles with narrow arguments. ${ }^{191}$ They focused on the Bank's necessity for limited fiscal functions, primarily the collection of taxes; Gallatin argued that the Bank was "necessary for the punctual collection of the revenue, and for the safe-keeping and transmission of public moneys." ${ }^{192}$ Other Bank supporters pointed out that the First Bank's notes provided currency that facilitated the payment of taxes, and that by their frequent practice extending credit to merchants so the latter could pay their taxes, banks put themselves in the role of helping to collect from taxpayers. ${ }^{193}$ To the extent that some of these arguments referred to banks generally, rather than a national bank,

186 Banknotes not accepted by the First Bank as valid payment of taxes would likely depreciate in value. State banks would be compelled either to redeem their notes held by the First Bank in specie, or suffer depreciation of their notes. But as their specie reserves declined to meet the First Bank's redemption demands, they would have to reduce their loans and note circulation to avoid further depreciation. Also, many state bank charters set limits on the ratio between the banks' debts (notes and loans) and their capital. Id. at 188-89, 198.

187 Id. at 199

188 CURRIE, supra note 182, at 251.

189 Id. at 251.

190 Id. at $250-51$.

191 Id. at 251-52.

$192 I d$

193 Id. 
some opponents argued that the existence of state banks meant that a national bank was not indispensably necessary and was thus unconstitutional (as falling outside the Necessary and Proper Clause). Bank supporters countered that implied powers need only be "fairly suited to, and well calculated for, legitimate national objects" and that it was improper to force the national government to rely on state banks: the purpose of the Constitution was to make the United States independent of the states for the means to carry out its objects. ${ }^{194}$

Although the debates in Congress were dominated by constitutional arguments, these were well-worn and lackluster, and historians are skeptical about their sincerity. Congressional votes against the Bank seem to have been motivated by "real animosities, personal, social, and partisan," and by the strong presence of state banking interests. ${ }^{195}$ The House bill to renew the charter was defeated by a single vote on January 24. ${ }^{196}$ A Senate bill, submitted on February 5, was defeated on February 20 when Vice President George Clinton cast a tiebreaking vote against the Bank. ${ }^{197}$ While Clinton explained his vote with the claim that Congress lacked the power to charter corporations, his real motivation seems to have been to spite his intra-party political enemies, Madison and Gallatin. ${ }^{198}$

\section{Marshall and the First Bank's History}

Marshall was well aware of what was said by Hamilton and by the First Bank's supporters in the House debates. In his Life of George Washington, written between 1804 and 1807, Marshall described Hamilton's Bank Report as "containing a copious and perspicuous argument on the policy of the measure." ${ }^{199}$ Marshall went on to summarize the House debates on the bill. Identifying the key opponents and supporters of the measure, Marshall summarized the debate as turning on the question of implied powers, which opponents argued were restricted to enactment of "that mean without which the end could not be produced." 200 The supporters responded that "when a

\footnotetext{
194 Id. at 251-53.

195 HAMMOND, supra note 59, at 234; see also id. at 214 (noting "[o]ne feels some skepticism when arguments that had been made by James Madison twenty years before were now offered with great earnestness by" business entrepreneurs and constitutional nationalists like Henry Clay and Daniel Webster); CURRIE, supra note 182, at 254 (noting the same). CURRIE, supra note 182, at 253; KILLENBECK, supra note 15, at 49.

197 CURRIE, supra note 182, at 253; KILLENBECK, supra note 15 , at 50.

198 CURRIE, supra note 182, at 252-53; HAMMOND, supra note 59, at 223; KILLENBECK, supra note 15 , at $49-51$.

199 4 John MARShall, The Life of GEORGE WASHINGTON 390 (rev. ed. 1926).

$200 \quad$ Id. at 392.
} 
power is delegated to effect particular objects, all the known and usual means of effecting them, must pass as incidental to it." ${ }^{201}$ Marshall then recounted that this debate was replayed in Washington's cabinet, summarizing the arguments in detail in a seven-page appendix. ${ }^{202}$

Significantly, Marshall made special note of the argument that a national bank was supported by the Commerce Clause. The Bank's supporters "took a comprehensive view of those powers, and contended that a bank was a known and usual instrument by which several of them were exercised," noting that "the utility of banking institutions" was demonstrated by the fact that "[i]n all commercial countries they had been resorted to as an instrument of great efficacy in mercantile transactions." 203

Despite noting the connection between pro-Bank arguments and broad, affirmative arguments for national power, Marshall derives a moral to the episode that is more consistent with defensive, unionpreserving nationalism than with aggressive, power-expanding nationalism. To Marshall, the Bank debates illustrated the broader "conflict between the powers of the general and state governments," that underlay the adoption of the Constitution, with "[t]he old line of division ... still as strongly marked as ever." ${ }^{204}$ One party "retained the opinion that liberty could be endangered only by encroachments upon the states," and "the other party ... sincerely believed that the real danger which threatened the republic was to be looked for in the undue ascendency of the states." ${ }^{205}$ This party believed it necessary "to guard the equilibrium established in the constitution, by preserving unimpaired all the legitimate powers of the union." ${ }^{206}$ The debate over the National Bank, Marshall concluded, "made a deep impression on many members of the legislature; and contributed, not inconsiderably, to the complete organization of those distinct and visible parties, which, in their long and dubious conflict for power, have since shaken the United States to their centre." 207 This unionpreserving focus anticipates Marshall's approach to the McCulloch decision a decade or so later.

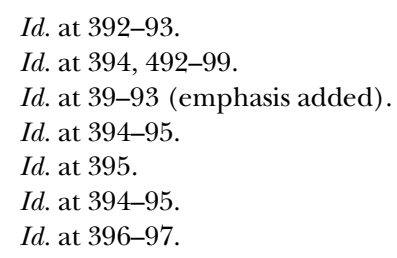




\section{The War of 1812 and the Call for a Second Bank}

The First Bank closed its doors forever when its charter expired in February 1811. The timing proved inopportune, creating something of a financial crisis. The dissolution of the First Bank and its regulatory impact led naturally to a further explosion of state banks, eager to feed the demand for credit. As state banks increased in number from ninety to 246, Gallatin estimated that their banknote circulation increased from $\$ 28$ million to $\$ 68$ million. ${ }^{208}$ The inflationary impact of this profusion of paper money was worsened by the fact that it outpaced the volume of economic transactions, as exports and the domestic coasting trade were severely damaged by the War of $1812 .{ }^{209}$ At the same time, the Federal Government needed large loans to finance the war. These had to be negotiated piecemeal with numerous smaller state banks on various terms, and in various locations, with actual funds not necessarily available where the government needed them, if the loans could be obtained at all. ${ }^{210}$

In August 1814, the British raids on Washington and Baltimore touched off a run on the banks in Baltimore, Philadelphia, and New York as customers sought to withdraw specie. ${ }^{211}$ The banks in those major commercial centers had to suspend payments of specie, which created something of a domino effect: suspension of specie payments spread to banks throughout the country, except New England. ${ }^{212}$ This event, though novel, resembled the state governmental failures to redeem paper money that had plagued the preConstitution economy and demonstrated that banks, like governments, could issue paper obligations beyond their means to repay. ${ }^{213}$ Interestingly, the suspension of specie payments did not cause a cascade of bank failures. Banks continued to operate, indeed turning significant profits, and their paper continued to circulate. The main consequence of suspension was the heavy and non-uniform discounting of banknotes, which varied in value "not only from time to time but at the same time from state to state and in the same state from place to place."214 A dollar in circulating banknotes might be valued at anywhere from par to seventy-five cents, but without the First Bank as tax collecting agent and with specie payments suspended, the

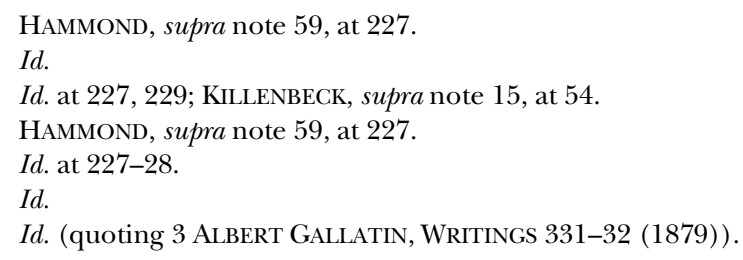


Treasury had to accept these discounted banknotes in payment of taxes. $^{215}$ This worsened the Federal Government's already grave revenue situation: most federal revenue was derived from duties on foreign trade, which was significantly down due to the war. ${ }^{216}$ Efforts to raise money through bond issues was dismal: it was eventually determined that, due to discounting and the scarcity of specie, some $\$ 80$ million in Treasury bonds issued by the government during the War of 1812 produced specie values of only $\$ 34$ million. ${ }^{217}$ Soldiers were paid in depreciated paper currency (sometimes in notes that the government would not itself accept in payment of taxes) and the Treasury found itself "obliged to borrow pitiful sums" simply to keep basic government operations going-to pay its stationery bill, for example. ${ }^{218}$

Against this backdrop, Congress began considering a second national bank charter in October 1814. But a bill approved by Congress in January 1815 was vetoed by President Madison, because he found the bill inadequate on policy grounds. ${ }^{219}$ Yet in the veto message, Madison acknowledged that his personally held constitutional objections were "precluded ... by repeated recognitions" of the constitutionality of the First Bank "in acts of the legislative, executive, and judicial branches" coupled with "a concurrence of the general will of the nation." 220 Despite Madison's constitutional blessing, Congress failed to pass another bank bill before it recessed for the year in March. ${ }^{221}$ But Madison, the First Bank's erstwhile opponent, was now adamant in his support for a new bank, and in his next annual message in December 1815, he again urged Congress to submit a new bank bill. ${ }^{222}$ On behalf of a House committee formed "on that part of the President's Message which relates to an Uniform National Cur-

\footnotetext{
215 HAMmOND, supra note 59, at 228-29.

$216 I d$.

$217 \quad I d$. at 229.

218 Id. at 230

$219 \quad I d$. at 231-32.

220 James Madison, Veto Message, 1 A Compilation of the Messages and PAPERs OF the PRESIDENTS, 1789-1897, at 555-57 (James D. Richardson ed. 1898). Specifically, the proposed charter omitted any requirement that the Bank furnish loans to the government, which Madison was concerned would not be forthcoming in wartime, when credit was tight but most needed by the government. Further, and related to this, a requirement in the bill that the Bank pay its obligations in gold and silver would undermine its ability to increase the money supply with a uniform paper currency. Id.

221 HAMMOND, supra note 59, at 232. A pending bill was permanently tabled in February 1815, when Congress received news of the signing of the Treaty of Ghent ending the war with Britain. Id. 
rency," South Carolina representative John C. Calhoun introduced a new Bank Bill on January 8, 1816. ${ }^{223}$

\section{Constitutional Arguments: Madison, Calhoun, and the Money Supply}

By this time, the sixteenth year of the Jeffersonian party's domination of national politics, the tenor of constitutional debate over the Bank had shifted somewhat, along with the political center, in a slightly strict constructionist direction. Hamilton had argued that "[t]he expediency of exercising a particular power, at a particular time, must indeed depend on circumstances; but the constitutional right of exercising it must be uniform and invariable-the same today as tomorrow." ${ }^{224}$ But Jeffersonian bank supporters seemed to suggest that the need for a national bank was dependent on circumstances, and had to be pegged to a current and compelling need. With the war and the need for government borrowing over, the borrowing power thus did not seem to be a viable argument to sustain the proposed Second Bank. Madison set the tone by emphasizing that a bank was needed because "[t]he benefits of a uniform national currency ... should be restored to the community." ${ }^{225}$ Gold and silver were in short supply due to the war; during this "temporary evil . . . until they can again be rendered the general medium of exchange," Congress should "provide a substitute which shall equally engage the confidence and accommodate the wants of the citizens throughout the Union." ${ }^{226}$ To accomplish this, Congress would have to choose between notes issued either by state banks, by a national bank, or directly from the U.S. Treasury. But, as both Madison and his new Treasury Secretary Alexander Dallas pointed out, state banks were not a promising solution, since it was their notes that were causing the problem. ${ }^{227}$

Significantly, Madison failed to explain the precise constitutional basis for a national power to issue notes as a general medium of exchange-that is, paper money. Strict constructionists and hardmoney advocates throughout the nineteenth century argued that the Coinage Clause (the power "to coin Money [and] regulate the Value

29 ANNALS OF CONG. 494 (1816).

8 HAMilton, supra note 152, at 102.

HAMMOND, supra note 59, at 233.

Madison, supra note 220, at 565-66 (emphasis added). But see 29 ANNALS OF CONG. 506 (1816) (statement of Alexander Dallas) (noting that a national bank's services "will be required, under every change of circumstances, in a season of war, as well as in the season of peace, for the circulation of the national wealth").

227 HAMmOND, supra note 59, at 233; Madison, supra note 220, at 565-66. 
thereof"228) impliedly prohibited the national government's issuance of paper money. The argument for a paper money power could come from three places, either alone or in combination: (1) a liberal construction of the Coinage Clause; (2) the Commerce Clause, since a uniform currency would facilitate interstate trade; or (3) an inherent or implied sovereign power to determine the nature of the nation's currency. Given Madison's peculiar admixture of pragmatism and strict constructionism, it is not surprising that he cagily declined to specify which of these grounds he was relying on, since none of them are quite consistent with strict construction.

This time around in Congress, the constitutional arguments were limited. "The question of constitutionality, which had so much sincere prominence in 1791 and so much insincere prominence in 1811, had none at all in these debates of 1814, 1815, and 1816." ${ }^{229}$ Opposition in Congress was limited to the few remaining hard-line Jeffersonians joining with the few remaining Federalists, who continued to oppose the Bank on partisan grounds, and the debates focused mostly on practical questions. ${ }^{230}$

A significant exception was the February 26, 1816 floor speech by Calhoun, which focused on "the cause and state of disorders of the national currency, and the question whether it was in the power of Congress, by establishing a National Bank, to remove those disorders." ${ }^{231}$ Calhoun began by elaborating on the Madison administration's position. The nation's currency consisted entirely of state banknotes, which were "extremely depreciated, and in degrees varying according to the different sections of the country," a state of affairs which "was a stain on public and private credit." Among the "embarrassments" of non-uniform, depreciated currency was the payment of government contracts and debts in depreciated currency, and inequalities in tax payments in violation of the constitutional requirement of equality: "the people in one section of the Union [might] pay perhaps one-fifth more of the same tax than those in another." ${ }^{233}$

U.S. CONST. art. I, $\S 8$, cl. 5 .

HAMMOND, supra note 59, at 233.

Id. at 233, 239-40.

29 ANNALS OF CONG. 1060 (1816) (statement of Rep. Calhoun); HAMmond, supra note 59, at 234 ("The outstanding discourse on the subject was John C. Calhoun's, which centered attention for the first time upon the monetary questions involved," offering an analysis that was "novel, perspicuous, and realistic.")

29 ANNALS OF CONG. 1060 (1816) (statement of Rep. Calhoun). Id. at 1065 . 
But Calhoun pressed the constitutional argument further. The Constitution gave Congress, in express terms, the power to regulate the currency of the United States, pursuant to its express power to "coin money." The Coinage Clause, Calhoun argued, was a power "to give a steadiness and fixed value to the currency of the United States." When the Constitution was adopted, he argued, the money supply was weighted down by depreciated state treasury notes-paper money printed by state governments-which the Framers believed "could only be regulated and made uniform by giving a power for that purpose to the General Government." 235 The states were incapable of producing a uniform national currency. ${ }^{236}$ "[T]aking into view the prohibition against the States issuing bills of credit,... [there is] a strong presumption this power was intended to be exclusively given to Congress." 237 To be sure, the problem in 1787 was not state banknotes, because at that time "there was but one, the Bank of North America," with a capital of only $\$ 400,000$ and whose discipline and solidity meant that its notes were always redeemable for gold and silver. ${ }^{238}$ "No man ... in the Convention ... could possibly have foreseen" the rise of state banks, "that they would have multiplied from one to two hundred and sixty; from a capital of four hundred thousand dollars to one of eighty millions"; and "that so far from their credit depending on their punctuality in redeeming their bills with specie, they might go on, ad infinitum, in violation of their contract, without a dollar in their vaults." 239 This "extraordinary revolution in the currency of the country," though its source was state-chartered banks rather than state treasuries, nevertheless violated the spirit of the provisions granting the general government the power to impose uniformity on the currency. ${ }^{240}$ This power was fundamentally an implied power from the nature of sovereignty-an argument hinted at by Hamilton in his 1791 memorandum and not embraced by the Supreme Court until 1884. ${ }^{241}$ "The right of making money" Calhoun asserted, is "an attribute of sovereign power, a sacred and important right." ${ }^{242}$ This power was being "exercised by two hundred and sixty

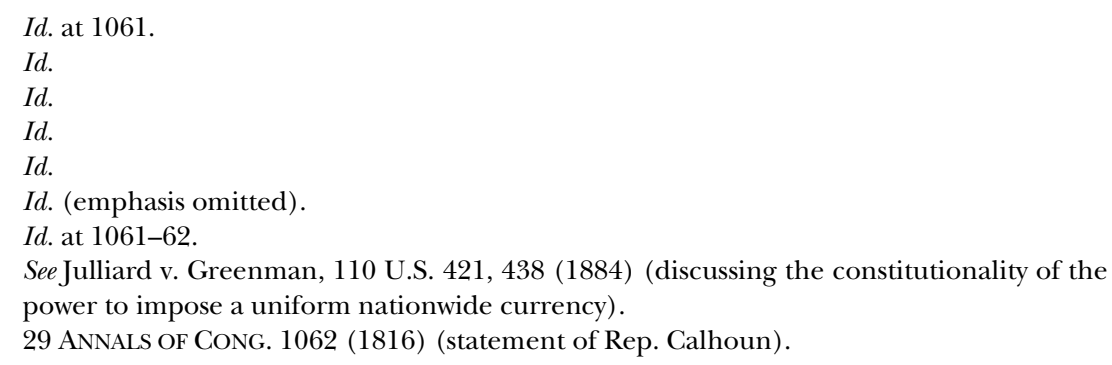


banks, scattered over every part of the United States, not responsible to any power whatever for their issues of paper." ${ }^{43}$

The nature of the problem itself demonstrated that the power to correct it necessarily resided in Congress. Calhoun estimated that the state banks held specie in their vaults of around $\$ 15$ million with another $\$ 67$ million in other capital, on which $\$ 170$ million was circulating in the form of banknotes, credits and other bank paper. ${ }^{244}$ This "prodigality" caused the banknotes to depreciate to the degree "that this paper was emphatically called trash or rags." ${ }^{245}$ This depreciation of currency caused an outflow of gold and silver which in turn caused further depreciation and led to the suspension of specie payments, which "stood as cause and effect; first, the excessive issues caused the suspension of specie payments, and advantage had been taken of that suspension to issue still greater floods of it." ${ }^{246}$ Banks might act voluntarily in concert to call in their notes and resume specie payment, but their money-making incentive would keep them from doing so. Therefore, "it rested with Congress" to produce concerted activity and "make them return to specie payments by making it their interest to do so." "247

The best means of accomplishing this was with a national bank. By conscientiously redeeming its own notes for specie, and refusing to accept non-redeemable notes from other banks, a national bank would discipline the state banks. It would "strip the banks refusing to pay specie of all the profits arising from the business of the Government, to prohibit deposits with them, and to refuse to receive their notes in payment of dues to the government." ${ }^{248}$ If banks still refused to resume specie payments, Congress could consider more drastic measures. The restoration of specie payments "would remove the embarrassments on the industry of the country and the stains from its public and private faith." ${ }^{249}$

Calhoun's argument is notably Hamiltonian. Although Calhoun focused on a particular present crisis in the money supply, he grounded the power to charter a bank on a synergistic reading of several constitutional provisions together with the broad claim that currency control is an inherent attribute of sovereignty. Moreover,

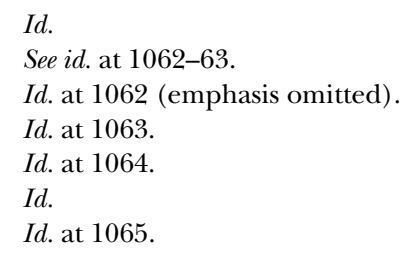


the national power to impose a uniform currency was not simply a power to issue national treasury or banknotes, but also necessarily entailed a power to regulate the money supply by exerting control over the nation's banking system. Buttressing the argument for federal constitutional authority was the practical problem of a state race-tothe-bottom. Because a (chaotic) state banking system had emerged since Hamilton's time, Calhoun could see more clearly than Hamilton that a national bank had a central banking function to exercise: disciplining state banks' creation of money. ${ }^{250}$

\section{MCCULLOCH'S CONTEXT: INTERNAL IMPROVEMENTS}

The question of Congress's power to charter a national bank was part of a larger set of questions that dominated national constitutional and policy debate for much of the twenty years prior to $\mathrm{McCulloch}$. The leaders of the nationalist side of this debate over the years included Alexander Hamilton, John C. Calhoun, John Quincy Adams, and several less-remembered senators and congressmen. The most important of these leaders in the congressional debates was Henry Clay, whose

long and dogged battle for a legislative program of aggressive measures to strengthen the national economy . .. came to be called the American System. Its principal elements were the Bank, internal improvements, and the protective tariff. Each required an expansive interpretation of congressional authority; each was vigorously opposed by dedicated defenders of states' rights. Together they presented the dominant constitutional controversies of the period in the domestic field. ${ }^{251}$

Chief Justice John Marshall's nationalism in McCulloch (or otherwise) cannot be adequately judged without reference to these controversies, but especially internal improvements. By early 1819, Marshall would have been fully aware that the most contentious political issue involving implied powers was not the Bank, but internal improvements. ${ }^{252}$ More specifically, the question was whether a power to build roads could be implied from the Commerce Clause or other enumerated powers. The arguments pro and con had been exten-

250 See HuRst, supra note 103, at 57, 159-63 (explaining central banking function). Hurst argued that U.S. policymakers did not comprehend the nature of a central banking function before Nicholas Biddle's assumption of the presidency of the Second Bank in 1823. Id. But clearly, Calhoun did understand it.

251 CURRIE, supra note 182, at 250 (citations omitted).

252 See Gunther, supra note 34, at 7-9 (discussing the controversy over the constitutionality of internal improvements to the Bank); see also NEWMYER, supra note 23, at 301 (explaining the delicate manner with which Marshall approached legitimizing internal improvements to the Bank). 
sively debated in Congress and between Congress and three successive presidents.

The Bank controversy itself cannot be fully understood without reference to the rest of the American System. The arguments for congressional power embraced or ignored in the Bank debate would also have had implications readily apparent to lawmakers at the time for the internal improvements question. Thus, what Marshall did and did not say in McCulloch touching on the question of internal improvements, speaks volumes about the scope of that decision's nationalist commitments.

\section{A. The Internal Improvements Controversy}

To a degree that is quite alien today, questions of public policy during the antebellum period were frequently debated in the political branches as questions of constitutional interpretation. ${ }^{253}$ Prior to the emergence of slavery as the dominant political issue, the most sustained and significant constitutional debates in the antebellum period concerned government involvement in infrastructure projects. Called "internal improvements" in antebellum parlance, "these projects included roads, canals, harbors, lighthouses, and, later, railroads." ${ }^{254}$ Debates over internal improvements certainly included the same kinds of issues involved in contemporary debates over public works and infrastructure projects—whether the projects are feasible and economically justified, which regions or legislative districts will receive the benefits of government spending, etc. But, unlike today, the debates were often framed as federalism questions: whether the federal government had the power to engage in the projects. ${ }^{255}$ There was no doubt of a state's power to improve its internal infrastructure, except to the extent that a state project might somehow obstruct interstate commerce. But states often lacked either the

253 According to Alison LaCroix, the antebellum period "witnessed the emergence of the Constitution as the preeminent organizing lens through which Americans viewed political and legal questions." Alison L. LaCroix, The Interbellum Constitution: Federalism in the Long Founding Moment, 67 STAN. L. REv. 397, 400 (2015). This point is exemplified throughout David Currie's masterful four volume work, The Constitution in Congress (1997-2005), analyzing debates on constitutional aspects of federal legislation from 1789 through 1861. Simply put, "[b]efore 1800 nearly all of our constitutional law was made by Congress or the president, and so was much of it thereafter." Preface to CURRIE, supra note 120, at x.

254 LaCroix, supra note 253, at 400; accord CURRIE, supra note 182, at 250, 258-83 (describing the political debates over internal improvements during Madison's presidency); HowE, supra note 20, at 203-84 (discussing the internal improvements made during the early $1800 \mathrm{~s})$.

255 CURRIE, supra note 182, at 258-59. 
money to pursue ambitious internal improvement projects, or the self-interest. A road through a state or a canal connecting navigable waterways might benefit trade between the terminal points of the route without significantly benefiting the states in between. Thus, as a matter of both resources and interstate interests, the call for federal involvement in internal improvements could be compelling.

Less clear was the question of federal constitutional authority to engage in internal improvement projects. Opponents of federal internal improvements measures could, and did, object that there was no general power over internal improvements in the Constitution, and that such a power could not be fairly implied from the enumerated powers. Presidents Jefferson, Madison, and Monroe made policy decisions reflecting deep ambivalence between a principle of "strict construction" of the powers of Congress, on the one hand, and a seeming desire to build up the national infrastructure, on the other. $^{256}$ Each of these presidents grudgingly acknowledged some congressional power over internal improvements at some point, each asserted general principles of constitutional limitation inconsistent with what they had elsewhere approved, and each recommended adoption of a constitutional amendment to authorize internal improvements, on the theory that the existing Constitution did not. ${ }^{257}$ In opposition to their views were those of bullish internal improvements advocates, such as Calhoun and Clay, who believed that the Constitution gave Congress a power over internal improvements. ${ }^{258}$ The views of these leaders, while controversial, commanded sufficiently widespread support to be well within the mainstream of political debate.

Debates over internal improvements issues developed a significant body of constitutional arguments. Nationalist proponents of the American System generally argued that the constitutional authorization for Congress to undertake internal improvements projects was implied by the commerce, postal, and war powers. The Commerce Clause argument rested on legislative precedent: from the first Congress, the Federal Government had built and maintained a nationwide system of aids to navigation, creating a legislative precedent for internal improvements under the commerce power, which was widely held to embrace navigation. ${ }^{259}$ This precedent also weighed in favor of a liberal construction of "regulating" commerce to extend to facilitating it. Senator James A. Bayard of Delaware, in an 1807 committee

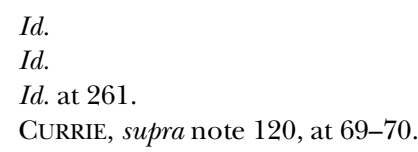


report endorsing a bill for constructing a canal to link the Delaware and Chesapeake Bays, argued that

$[t]$ he power to erect light-houses and piers, to survey and take the soundings on the coast, or erect public buildings, is neither expressly given nor recognised [sic] in the Constitution, but it is embraced by a liberal and just interpretation of the clause in the Constitution, which legitimates all laws necessary and proper for carrying into execution the powers expressly delegated. On a like principle the bank of the United States was incorporated. Having a power to provide for the safety of commerce and the defence of the nation, we may fairly infer a power to cut a canal, a measure unquestionably proper with a view to either object.

During an 1816 debate on the "Bonus Bill," ${ }^{261}$ Representative Daniel Sheffey of Virginia expanded on this theme. Arguing against a narrow construction of "regulate" in the Commerce Clause, Sheffey asserted that "the word "regulate" means "an entire control over the subject in all its relations." 262 Commerce "regulation" had served as the constitutional basis on which

Congress ... have erected light-houses, piers, and beacons; they have established regulations for seamen in the merchant service; they have levied a capitation tax on these seamen ... to create hospitals for the sick and disabled .... Under the power to "regulate" commerce with the Indian tribes, trading houses have been erected and roads opened. Did any person ever object to these acts . . . as transcending the Constitutional powers of this Government? ${ }^{263}$

With the often-embarrassing military performance of the United States in the recently concluded War of 1812 freshly in mind, Sheffey added that "defence against foreign invasion" required that "roads and canals" were indispensable to the necessity of "collecting and concentrating your forces; transporting subsistence, arms, and munitions; and maintaining communication" among the forces. ${ }^{264}$

Opponents of internal improvements legislation tended to make strict constructionist arguments against implied powers or in favor of narrow constructions of granted powers. The power to establish post roads was not to build them, but merely a power to designate existing roads and reserve a right of passage; and that the power "to regulate" commerce meant only a power to "prescribe the manner, terms, and

\footnotetext{
260 CURRIE, supra note 182, at 120 (emphasis added).

261 The Bonus Bill was a proposal, introduced to the House by John C. Calhoun, to create a fund to use as seed money for unspecified future internal improvements projects. The money was to come from a $\$ 1.5$ million "bonus" required to be paid by the Second Bank to the Treasury, as consideration for its charter rights. Id. at 260-69. 
conditions, on which that commerce should be carried on"-not a power to promote commerce. ${ }^{265}$ In short, Congress had no peacetime power to build roads. The war powers could not justify building roads when there was no war on. ${ }^{266}$ Both Presidents Madison, prior to McCulloch, and Monroe after it, issued controversial vetoes of major internal improvements bills on such grounds. ${ }^{267}$

Internal improvement supporters vehemently disputed these points. The general government could not be made to depend on states for the execution of its powers; therefore, the Postal Clause necessarily authorized the building of roads and, as Clay argued, once a road was built for a legitimate national purpose-say, as a military or post road-it would not matter constitutionally if, subsequently, the majority of traffic were commercial. ${ }^{268}$ Similarly, in his January 1819 report to the House on military roads, Calhoun (by this time Secretary of War) wrote that "a judicious system of roads and canals, constructed for the convenience of commerce and the transportation of the mail only, without reference to military operations, is itself among the most efficient means for 'the more complete defense of the United States." ${ }^{69}$ This was because "[t]he roads and canals which such a system would require are, with few exceptions, precisely those which would be required for the operations of war." 270 The report further recommended using the army to build roads and canals. ${ }^{271}$

\section{B. McCulloch and Internal Improvements}

The implications of McCulloch for internal improvements must have been obvious to observers less keen than Marshall. The internal improvements debates turned primarily on interpretive latitude to be given both implied powers and at least four enumerated powerscommerce, post office, war, and territories. All four of these were implicated in the Bank debates, and the arguments pro and con made over the years in congressional debates surfaced in the McCulloch oral argument. The internal improvements issue was squarely

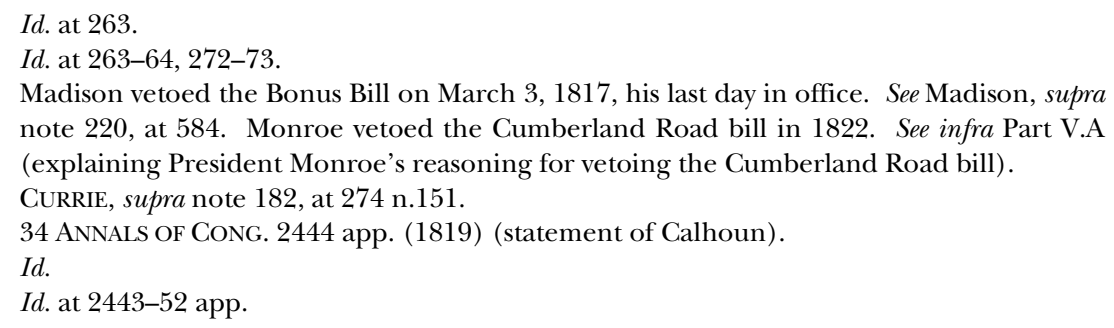


presented. There is no doubt that the nationalist arguments were discernable, in the records of congressional debates and at oral argument, for Marshall to draw on. He would not have had to go out very far on a political limb to do so. ${ }^{272}$ Did Marshall have a go at internal improvements? We shall see.

\section{THE MCCULLOCH CASE}

\section{A. The Litigation}

We return to the Bank saga where we left off. The bill to charter the Second Bank passed both houses in March and April 1816, after a few weeks of limited debate in which the Republicans overcame the internal divisions that had scuttled the First Bank in 1811. The bill was signed by President Madison on April 10, 1816. ${ }^{273}$ The Second Bank, like the First, was fundamentally a private corporation, with some government participation. Of its twenty-five directors (all of whom were required to be U.S. citizens), five were to be appointed by the President, and $20 \%$ of the Bank's stock would be owned by the Federal Government. ${ }^{274}$

The Second Bank did not get off to a good start. Its first president, William Jones, was not a competent financier, and the Second Bank was ineptly managed in some key respects. ${ }^{275}$ The Second Bank promptly established branch offices in sixteen states, which enabled it to fulfill one of its functions of moving federal funds around the country. ${ }^{276}$ But it also undertook a policy of aggressive competition with state-chartered private banks (something the First Bank had not done, despite Hamilton's vision of the Bank as a major commercial lender). ${ }^{277}$ This tended to provoke state legislatures, many of which sought to impose taxes on the Bank, motivated either by a distrust of banks generally or to curtail the Second Bank's competitive position in favor of their own chartered banks. ${ }^{278}$ The Second Bank also found itself overextended due to its aggressive lending policy, and in late

272 For example, four House resolutions on internal improvements drew substantial support in 1818. A power to appropriate money for internal improvements passed, and three others, recognizing a congressional power to construct roads and canals for postal, military, and even commerce-facilitating purposes, were narrowly defeated. 31 ANNALS OF CONG. 1381-89 (1818).

273 HAMMOND, supra note 59, at 233.

274 Id. at 244; ELLIS, supra note 6, at 42.

275 KILLENBECK, supra note 15 , at 64-66.

$276 \quad I d$. at 64.

277 Id. at 65-66.

278 Id. at 68-69. 
1818 it abruptly and aggressively began calling in many of its loans as the economy entered a downturn. ${ }^{279}$ The rapid contraction of credit exacerbated (if it did not cause) a depression that became known as the Panic of $1819 .^{280}$ The public perception of the Bank turned increasingly negative. ${ }^{281}$

This was the context in which McCulloch $v$. Maryland arose. James $\mathrm{McCulloh}^{282}$ was the "cashier" (the manager) of the Baltimore branch of the Second Bank of the United States. ${ }^{283}$ Under his management, the Baltimore branch sought to evade control of the central Bank office, and was particularly aggressive in extending easy credit to outcompete state banks for commercial lending business. ${ }^{284}$ McCulloh and his cronies also used the branch to engage in widespread financial manipulation and outright fraud. ${ }^{285}$ In February 1818, Maryland enacted a law "to impose a Tax on all Banks, or Branches thereof in the State of Maryland not chartered by the [Maryland] Legislature." ${ }^{286}$ The tax was imposed on notes issued by the Bank, ranging from $\$ 0.10$ to $\$ 20$, depending on the amount of the note. ${ }^{287}$ Failure to pay the tax was punishable by fines of $\$ 100$ for each offense. ${ }^{288}$ A bank could obtain a waiver of the tax by paying $\$ 15,000 .{ }^{289}$ When the law went into effect in May 1818, McCulloh issued notes without paying the tax, and a Maryland treasury official brought an action for debt against McCulloh, as Bank cashier, to collect $\$ 2,500$ in penalties on five notes. ${ }^{290}$ The parties agreed on a statement of facts and a Baltimore County court ruled that the Bank owed the tax. The Maryland Court of Appeals (then the state's highest court) affirmed. ${ }^{291}$

\section{B. The Oral Arguments}

The case was argued before the U.S. Supreme Court beginning on February 22, $1819 .^{292}$ Some of the leading lawyers in the nation ar-

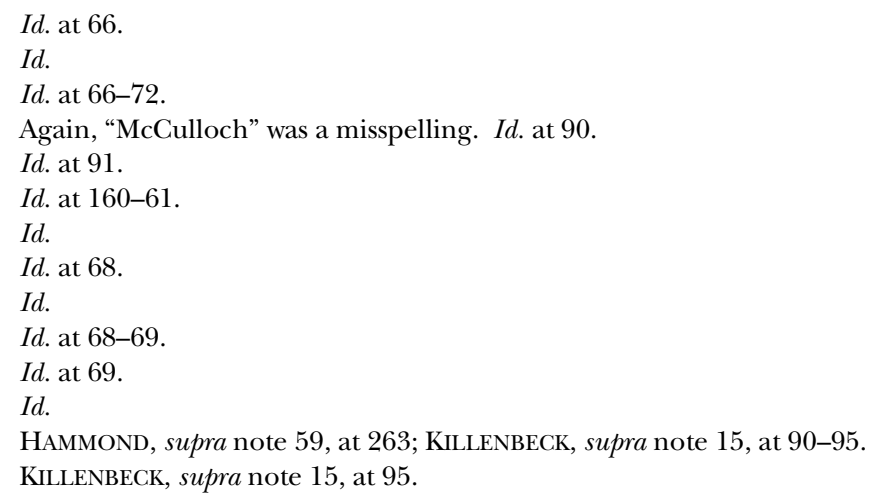


gued the case. The lawyers for Maryland included Luther Martin, Joseph Hopkinson, and Walter Jones. ${ }^{293}$ The Bank's legal team included Daniel Webster and U.S. Attorney General William Wirt, but these two luminaries were outshone by the third and final member of the team, William Pinkney. ${ }^{294}$ The argument lasted nine days, wrapping up on March $3{ }^{295}$ Three days later, the Court issued its decision. ${ }^{296}$

The usual broad brush reading of the arguments confirms two important and well-known points. First, counsel for Maryland based their arguments on aggressively strict-constructionist, anti-federalist views of the Constitution. Second, the McCulloch opinion consists almost entirely of Marshall's summary arguments made by others. Counsel for Maryland made the now-familiar arguments, that the Constitution's grants of powers must be strictly construed to protect the sovereign rights of the states. ${ }^{297}$ State sovereignty was, they argued, implicit in the nature of enumerated powers, in the Constitution's nature as a compact of the states, and in the assurances of limited national power made by the Constitution's supporters to overcome anti-federalist qualms in the ratification debates. ${ }^{298}$ Implied powers were limited to those absolutely or indispensably necessary to executing the granted power, as confirmed by the Necessary and Proper Clause and the Tenth Amendment. ${ }^{299}$ Chartering a bank was a sovereign power that could not be implied. ${ }^{300}$

These arguments, and a handful of others regarding the lack of a power to charter banks and the states' power to tax concurrently with the national government, are familiar to us because Marshall summarizes them as he proceeds to rebut them. ${ }^{301}$ Marshall's rebuttals are all adopted from arguments of the Bank's counsel, which in turn are thus familiar to us, even though Marshall understandably asserts them as the Court's opinion without attribution. Detailed recitation of those aspects of the oral argument that confirm these points would be unenlightening. What makes the oral argument worth a close read is to identify arguments made but not addressed or adopted by Marshall in the McCulloch opinion; these show the limits of what Mar-

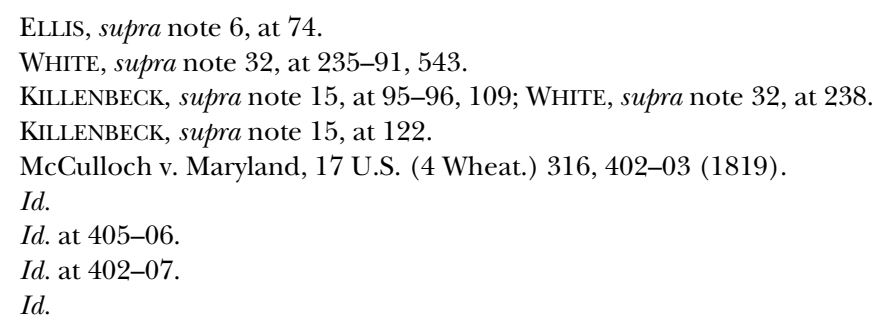


shall was willing to do to advance the cause of nationalism in $\mathrm{McCul}$ loch.

The lawyers for the Bank all cited its assistance to the government's fiscal operations as a constitutional basis. Thus, Webster asserted that a national bank "is a proper and suitable instrument to assist... in the collection and disbursement of the revenue [and] in the occasional anticipations of taxes and imposts." ${ }^{302}$ Ultimately, that is where Marshall would ground the Bank.

But Webster, Wirt, and Pinkney pushed beyond this point, to draw on the more far-reaching arguments previously made by Calhoun, Hamilton, and others. Chartering the Bank was in effect an exercise of a power to impose a uniform national currency and regulate the money supply. ${ }^{303}$ This power, in turn, was necessary and proper to commerce regulation- "the regulation of the actual currency, as being a part of the trade and exchange between States," according to Webster. ${ }^{304}$ Wirt contended that banks "dispersed throughout the country" are appropriate means for executing

the enumerated powers, such as, the power of levying and collecting taxes throughout this widely extended empire; of paying the public debts, both in the United States and in foreign countries; of borrowing money, at home and abroad; of regulating commerce with foreign nations, and among the several States; of raising and supporting armies and a navy; and of carrying on a war. ${ }^{305}$

Pinkney argued that the Bank was "intimately connected ... with all the financial operations of the government," including moving funds around the country, facilitating payment of debts and taxes, and issuing loans to the government. ${ }^{306}$ But he added that the Bank "has ... a close connection with the power of regulating foreign commerce, and that between the different States" by "provid[ing] a circulating medium, by which that commerce can be more conveniently carried on, and exchanges may be facilitated.," ${ }^{307}$

The advocates in the McCulloch oral argument also directly addressed the commerce power in terms clearly linking it to internal improvements. Insofar as we can tell from the argument summaries in the U.S. Reports, Maryland's counsel did not directly confront Madison's assertions that the Bank was a justifiable response to the

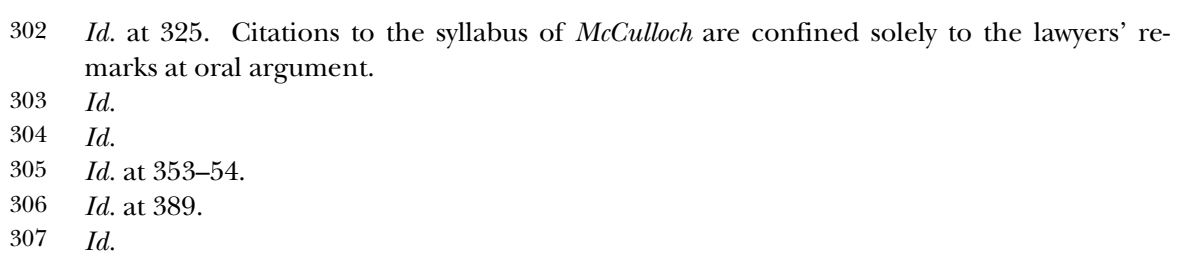


temporary problem of a specie shortage and resultant disuniformity in currency. They probably hoped to sweep the Madisonian middle ground under the rug, in order to aid their project of portraying the Bank in extreme consolidationist (ultranationalist) terms. Thus they described a parade of horribles in which the Bank would necessarily require justification under an unacceptably broad interpretation of the Commerce Clause. ${ }^{308}$ Walter Jones for Maryland joined issue on the Commerce Clause this way:

The people never intended they should become bankers or traders of any description. They meant to leave to the States the power of regulating the trade of banking, and every other species of internal industry; subject merely to the power of Congress to regulate foreign commerce, and the commerce between the different States, with which it is not pretended that this asserted power is connected. ${ }^{309}$

Jones argued further that to equate the charter of a bank with commerce regulation of any kind would be to authorize the establishment of "an East or a West India company, with the exclusive privilege of trading with those parts of the world." ${ }^{10}$ Even worse, in Jones's view, if Congress could incorporate a bank to regulate commerce, it could "create corporations for the purpose of constructing roads and canals; a power to construct which has been also lately discovered among other secrets of the constitution, developed by this dangerous doctrine of implied powers." ${ }^{111}$ Thus, Jones threw down a gauntlet on the Commerce Clause issue: by expressly linking the Bank's fate to internal improvements, he in essence dared the Marshall Court to issue a decision that would sustain both.

Like their adversaries, the Bank's legal team, too, declined to emphasize the Madisonian middle ground defense of the Bank. Pinkney took up Jones's challenge on the Commerce Clause/internal improvements issue, by echoing the argument made by Hamilton and various members of Congress in support of implied powers: "light houses, beacons, buoys, and public piers, have all been established under the general power to regulate commerce." ${ }^{312}$ Because "they are not indispensably necessary to commerce," the precedent demonstrates a congressional understanding that implied powers extended beyond the narrow confines of indispensably necessary measures. ${ }^{313}$ Pinkney's primary point was to illustrate that implied powers need

$\begin{array}{ll}308 & I d . \text { at } 419 . \\ 309 & I d . \text { at } 368 . \\ 310 & I d . \text { at } 365 . \\ 311 & I d . \text { at } 368 . \\ 312 & I d . \text { at } 385 . \\ 313 & I d . \text { at } 385-86 .\end{array}$


not be strictly necessary to be constitutional. But the hint to Marshall-inviting him to venture some dicta on internal improvements-must have been unmistakable.

Nor did the Bank's lawyers press the Madisonian argument relying on the immediate currency crisis as grounds to justify the Bank. Instead, they preferred to make arguments more nationalistic than Madison's grudging acceptance of the Bank as a constitutional fait accompli justified by temporary exigencies. There was no hint in the arguments of Webster, Wirt, or Pinkney that the power to incorporate the Bank was anything other than a permanent feature of the Constitution. Hopkinson had begun his argument for Maryland with a direct challenge to Hamilton's contention that "[c]ircumstances may affect the expediency of the measure, but they can neither add to, nor diminish its constitutionality." ${ }^{314}$ Consistent with what may have been a consensus position harmonizing strict construction with implied powers, Hopkinson had argued:

[A] power, growing out of a necessity which may not be permanent, may also not be permanent... The argument might have been perfectly good, to show the necessity of a bank for the operations of the revenue, in 1791, and entirely fail now, when so many facilities for money transactions abound, which were wanting then. ${ }^{315}$

Wirt responded by pointing out the danger in this mode of constitutional construction: it was "fatal to the permanency of the constitutional powers; it makes them dependent for their being on extrinsic circumstances, which, as these are perpetually shifting and changing, must produce correspondent changes in the essence of the powers on which they depend." ${ }^{16}$ For Wirt, past historical episodes including "a period of war, the calamities of which were greatly aggravated by the want of this convenient instrument of finance," could demonstrate the existence of a contemporary power by "furnish [ing] abundant experience of the utility of a national bank as an instrument of finance." ${ }^{\prime 17}$ Such a reference to the very recent War of 1812 had to have been a powerfully resonant example.

Finally, the Bank's lawyers' nationalism was evident in Pinkney's two arguments repeating Hamilton's arguments based on the Territorial Clause. First, the Territorial Clause afforded an analogy to the Bank. Under the power "to make all needful Rules and Regulations respecting the Territory or other Property belonging to the United

8 HAMilton, supra note 152, at 123.

McCulloch, 17 U.S. (4 Wheat.) at 331.

Id. at 355 .

$I d$. at 354 . 
States," ${ }^{318}$ Congress had created territorial governments. This power, which "has never been doubted," was a power to charter corporations, since governmental subdivisions created by the sovereign were long regarded as corporate charters. ${ }^{319}$ Second, was the more aggressive argument from this clause. As Pinkney put it, "If [the United States] may establish a corporation to regulate [its] territory, [it] may establish one to regulate their property. Their treasure is their property, and may be invested in this mode.. ${ }^{320}$ In other words, according to Pinkney, the Territorial Clause was another enumerated power from which the Bank could be implied directly.

Construing the Territorial Clause as a broad power to manage government property could have significant implications for expanding congressional power. The national government owned public lands both in the territories and within some state borders, and a power to manage those properties could support such measures as the building of roads and canals through states to reach federal lands, thereby increasing their value. In the McCulloch decision, Marshall adopted the narrower first argument analogizing corporate and territorial government charters. But he did not discuss the second, more aggressive argument.

\section{The Decision: Grounding the Bank}

Every year, first-year law students across the country pose two questions about $M c$ Culloch that are the constitutional law equivalent of the boy who saw that the emperor had no clothes: why wasn't the Bank constitutional under the Commerce Clause? And to what enumerated power is the Bank necessary and proper?

One of the off-putting features of Marshall's opinion in McCulloch is the difficulty of finding the answer to these questions. This has frustrated some legal scholars. According to David Currie, "Marshall never bothered to explain how the establishment of the Bank was necessary, proper, or even conducive to the execution of any of the powers expressly granted to Congress." ${ }^{321}$ Gerard N. Magliocca writes

\footnotetext{
318 U.S. CONST. art. IV, § 3, cl. 2.

319 McCulloch, 17 U.S. (4 Wheat.) at 386; see also 8 HAMILTON, supra note 152, at 128 ("It is admitted that with regard to the Western territory they give a power to erect a corporation-that is to institute a government."); 1 EUGENE MCQUILLIN, THE LAW OF MUNICIPAL CORPORATIONS $\$ 1: 9$ (3d ed. 2010) (discussing the chartering of municipal corporations by provincial governors in the colonies throughout the seventeenth and eighteenth centuries).

320 McCulloch, 17 U.S. (4 Wheat.) at 390.

321 CURRIE, supra note 120 , at 80.
} 
that Marshall was "vague about which powers supported the incorporation of the Bank, but he referred to the taxing, borrowing, commerce, and war powers." ${ }^{322}$ G. Edward White finds Marshall's vague and conclusory connection of the Bank to an enumerated power "the kind of reasoning in which Marshall indulged when he really did not want to examine an issue in detail." ${ }^{323}$ These criticisms echo Spencer Roane's pseudonymous editorial attack on McCulloch in the Hampden essays, which charged that "[the Bank's] friends have not yet agreed upon the particular power to which it is to be attached!"

In fact, Marshall upheld the Bank as "a convenient, a useful, and essential instrument in the prosecution of [the national government's] fiscal operations." ${ }^{325}$ Marshall does not analyze this conclusion, or support it beyond asserting that it is "not now a subject of controversy," because "statesmen" "concerned in the administration of our finances, have concurred in representing its importance and necessity." ${ }^{326}$ Referring to the Bank's long historical acceptance, with which he began the opinion, Marshall states that " $[\mathrm{t}]$ he time has passed away when it can be necessary to enter into any discussion in order to prove the importance of this instrument, as a means to effect the legitimate objects of the government." ${ }^{327}$ Marshall himself subsequently explained in his Friend of the Constitution essays, that

After a long and perspicuous review of the arguments which have been urged against the act of congress which was under consideration, the court proceeds to the act itself, and places its constitutionality simply on the ground, that a bank is "a convenient, and useful, and an essential instrument in the prosecution of the fiscal operations of the government." ${ }^{328}$

Simply, indeed. There is no doubt that Marshall tried to keep the Bank's enumerated power basis simple. The question is, why?

The concept of "fiscal operations" has two striking features. First, as noted, "fiscal operations" are not an enumerated power. Fiscal operations of the government include collecting taxes; depositing,

Magliocca, supra note 10, at 126 n.31.

WHITE, supra note 32, at 549.

Spencer Roane, Hampden Essays III, RICHMOND ENQUIRER, June 18, 1819, reprinted in MARSHALL'S DEFENSE, supra note 72, at 125, 133.

325 McCulloch, 17 U.S. (4 Wheat.) at 422.

$326 \quad I d$.

327 Id. at 423.

328 John Marshall, A Friend of the Constitution Essays, ALEXANDRIA GaZETTE, July 5, 1819, reprinted in MARSHALL'S DEFENSE, supra note 72, at 189-90. Here, Marshall very slightly misquoted the language from McCulloch. See McCulloch, 17 U.S. (4 Wheat.) at 422 ("That it is a convenient, a useful, and essential instrument in the prosecution of its fiscal operations ...."). 
transporting, and disbursing money; and perhaps the more mechanical aspects of borrowing. Clearly, these matters relate to some readily identifiable powers, such as taxing and borrowing powers, and other powers which require spending money for implementation. But "fiscal operations" are plainly legislative means. Putting it in Marshall's language, fiscal operations are "minor ingredients" or "subdivisions" of an enumerated power, but not an enumerated power in themselves. ${ }^{329}$ Accordingly, Marshall's Friend of the Constitution explanation does not really meet the criticism that he has failed to name an enumerated power.

This leads to the second, closely related point: "fiscal operations" are probably not a high-level government function. While "fiscal operations" could perhaps refer to questions of national financial policy, the more natural reading of that term is something less. The closest Marshall comes to defining what he means by fiscal operations is when he says that the power of "raising revenue, and applying it to national purposes, is admitted to imply the power of conveying money from place to place." 330 Thus, "fiscal operations" might mean nothing more than the basic handling of money: for example, a cashier redeeming a Treasury note for gold is a "fiscal operation," but the decision whether the note will be redeemable for gold is not, but is rather a matter of financial policy. Certainly, the term does not directly pertain to any regulatory power: neither the substance of tax laws, nor the substantive purposes of appropriations, nor the imposition of a uniform national currency, nor the regulation of commerce. "Administration of our finances" might be significantly broader than "fiscal operations," but Marshall does not say the Bank is necessary and proper to national finance; rather, he says that statesmen "concerned in" national finance have agreed that the Bank is useful-to fiscal operations. ${ }^{332}$

Marshall could easily have used language connecting the Bank to great questions of national financial policy. A leading statesman "concerned in" the nation's finances had been Calhoun in 1816, who

329 Marshall's distinction between implied powers as mere "subdivisions" or "minor ingredients" of enumerated powers, and enumerated powers as "great, substantive, independent" powers is discussed elsewhere. See supra note 94 and accompanying text; infra note 336 and accompanying text.

330 McCulloch, 17 U.S. (4 Wheat.) at 409. Samuel Johnson's Dictionary defines "fiscal" simply as a noun meaning "revenue." 1 SAMUEL JOHnSON, A Dictionary OF THE ENGLish LANGUAGE 808 (11th ed. 1797) [hereinafter SAMUEL JOHNSON's DictionARY].

331 See HuRst, supra note 103, at 80, 84-85 (defining "fiscal policy" as matters such as the movement of government deposits and rules for payments).

332 McCulloch, 17 U.S. (4 Wheat.) at 422. 
had made an impassioned argument for a congressional power to regulate the currency. However, McCulloch says nothing about any aspect of currency regulation: not the Second Bank's role in imposing discipline on state banks, nor even its role in issuing banknotes that could serve as a uniform national currency. This latter omission is particularly strange, since the McCulloch litigation arose as a dispute over the issuance of national banknotes. The Court struck down Maryland's tax on the Second Bank's notes-but nowhere does Marshall explicitly acknowledge that the Bank has a power, constitutionally conferred by Congress, to issue those notes! In sum, Marshall's on the relatively modest concept of "fiscal operations," even if that term could be stretched, suggests intentional avoidance of more farreaching, nationalistic claims.

Further, by not naming any particular enumerated power, Marshall begs a question of great importance to two sides of the Bank debate. Within the Jeffersonian Republican camp, both the Bank's supporters and moderate opponents believed that the Bank, if it were to be found constitutional, would have to be pegged to one power connected to an existing regulatory problem. ${ }^{333}$ Treasury Secretary Gallatin had argued that the Bank was necessary to the collection of taxes; Madison had argued that the Bank was necessary in the short term to establishing a uniform currency. ${ }^{334}$ The Bank's nationalist supporters argued that its constitutionality could be based on multiple clauses, either separately or in combination, and that no present exigency was required. Nowhere does Marshall endorse this view; on the contrary, some of his more celebrated language could be read to support the Madisonian view, that the Bank's constitutional basis as necessary and proper may be impermanent, lasting only as long as the currency crisis. Marshall famously tells us that "to endure for ages to come," the Constitution must "be adapted to the various crises of human affairs" and unforeseen "exigencies." ${ }^{335}$ Otherwise, Marshall avoided these controversies by refusing to identify any enumerated power as the basis for the Bank's constitutionality. Everyone could find room in Marshall's vagueness to argue one of their significant positions consistently with McCulloch. Nationalists could claim that fiscal operations related to multiple powers; moderate Jeffersonians could claim that the Bank was justified merely to facilitate tax collec-

333 See, e.g., id. at 331-32 (highlighting the notion of an existing regulatory problem). Hardline opponents opposed corporate charters per se and took the most restrictive view of the Necessary and Proper Clause. See supra note 101 and accompanying text.

334 See supra text accompanying notes 192, 225, 226.

335 McCulloch, 17 U.S. (4 Wheat.) at 415. 
tion until state banks resumed redemption of their notes in specie; and all Jeffersonians (even perhaps hard line strict constructionists) might have noted that Marshall did not endorse a general governmental power to regulate the currency. This sort of caginess fails to endorse any significantly nationalist argument pressed on the Court at oral argument or readily found in the Bank's history and congressional debates. If anything, Marshall's references to crises and exigencies lean in a Madisonian direction.

At the same time, Marshall's references to specific enumerated powers beyond "fiscal operations"-especially, to the commerce power-amount to little more than harmless flirtation. Marshall mentions the Commerce Clause (indeed, the word "commerce") only twice in the entire opinion, in both instances to make a general point about the nature of implied powers. In one passage, Marshall refers to the Commerce Clause as a "great, substantive and independent" power for purposes of distinguishing it from implied powers. ${ }^{336}$ In the other passage, Marshall makes the general point that great enumerated powers require implied powers for their execution:

Although, among the enumerated powers of government, we do not find the word "bank" or "incorporation," we find the great powers to lay and collect taxes; to borrow money; to regulate commerce; to declare and conduct a war; and to raise and support armies and navies. The sword and the purse, all the external relations, and no inconsiderable portion of the industry of the nation, are entrusted to its government. It can never be pretended that these vast powers draw after them others of inferior importance, merely because they are inferior. Such an idea can never be advanced. But it may with great reason be contended, that a government, entrusted with such ample powers, on the due execution of which the happiness and prosperity of the nation so vitally depends, must also be entrusted with ample means for their execution. The power being given, it is the interest of the nation to facilitate its execution. It can never be their interest, and cannot be presumed to have been their intention, to clog and embarrass its execution by withholding the most appropriate means. $^{337}$

Is Marshall suggesting here that the Bank is necessary and proper to the execution of the taxing, borrowing, commerce, war, and army/naval powers? If that were Marshall's point, he obscures it by burying it in the discussion of the existence of implied powers in general. Note that Marshall does not actually say that the Bank is jus-

336 See id. at 411 ("The power of creating a corporation, though appertaining to sovereignty, is not, like the power of making war, or levying taxes, or of regulating commerce, a great substantive and independent power, which cannot be implied as incidental to other powers, or used as a means of executing them."). 
tifiable under all—or any—of these powers; rather, his point seems to be that an inferior power like forming a corporation or creating a bank may well be implied to carry out great powers like commerce among others. Elsewhere, the opinion refers to other enumerated powers-such as the postal power-but only as illustrations, not directly as sources. ${ }^{338}$ Neither contemporary critics nor modern readers of $M c$ Culloch have read the above-quoted passage as a designation of the enumerated source of the implied power to incorporate a bank. In sum, in neither of the two instances mentioning the word "commerce," does Marshall suggest that the Commerce Clause might be a source from which to imply a power to incorporate a bank.

Reading the opinion carefully, one sees that Marshall never actually applies his own test of "necessary and proper" laws to the Bank. Even assuming for the sake of argument that "fiscal operations" are an acceptable stand-in for some unspecified enumerated powers, Marshall does not offer an explicit analysis of how the Bank is "conducive" or "well adapted." Instead, he tells us that financial experts find it so, and that "the time has passed" for reaching a contrary conclusion. ${ }^{339}$ Both G. Edward White and David Currie have speculated that Marshall believed the Bank could not persuasively pass his own "necessary and proper" test, and so he avoided the analysis to rig his pro-nationalist result. ${ }^{340}$ But White and Currie are both mistaken: Marshall avoided the analysis to make McCulloch less nationalistic, not more.

To apply his "necessary and proper test" to the Bank, Marshall would not only have had to identify one or more specific enumerated powers, but construe them as well. The most logical inference from McCulloch's failure to do so is that Marshall wanted to avoid interpreting any enumerated powers, and thereby embroiling the Court in further controversy. The Bank could easily have been shown to meet Marshall's necessary and proper test in connection with the taxing, borrowing, war, or commerce powers, or even the Territorial Clause. We have seen strong historical arguments for the national government's unmet need for a centralized private lender during the War of 1812. To rely expressly on the borrowing power or the war power in

Id. at 417 .

Id. at 422-23.

See WHITE, supra note 32, at 549 ("This was the kind of reasoning in which Marshall indulged when he really did not want to examine an issue in detail ...."); David Currie, The Constitution in the Supreme Court: State and Congressional Powers, 1801-1835, 49 U. CHI. L. REV. 887, 933-34 (1982) ("In short, Marshall devoted most of his effort to demolishing the straw man of indispensible necessity and slid over the real question of the propriety of the Bank itself."). 
peacetime would mean rejecting the Madisonian argument that the Bank's constitutionality depended on a link to a current exigency. To rely on the commerce power would provide support for the constitutional argument for internal improvements. Significantly, Marshall deemed it important to make direct refutations of two arguments of Maryland's counsel: the argument advancing compact thetheory, and the argument asserting that the Necessary and Proper Clause was a limiting provision.

But Marshall did not think it necessary or proper to make a direct and open refutation of Jones's argument that the power to incorporate a bank was unconnected to commerce. Lest there be any doubt about Marshall's awareness of the Bank's relation to commerce, consider his own statement about the First Bank in his Life of Washington: "the utility of banking institutions" was demonstrated by the fact that "[i]n all commercial countries they had been resorted to as an instrument of great efficacy in mercantile transactions." easily have repeated that statement in $M c$ Culloch—but he did not.

\section{The Decision: Internal Improvements}

The McCulloch opinion steers entirely clear, not only of commerce, but also of internal improvements. Marshall's examples of analogous legislative precedents for implied powers are unimpressive, and strikingly omit Pinkney's reminder that the building of light houses and other navigational aids demonstrate an implied power to regulate commerce. Webster had argued that the Bank's ability to regulate currency made it "a part of the trade and exchange between the States.” ${ }^{342}$ Marshall's unwillingness to embrace Webster's argument to the Court, or Calhoun's argument to Congress about a national power to regulate currency, is most plausibly seen as motivated by a desire to avoid linking the Bank to an interpretation of the commerce power that would support internal improvements.

Embracing Pinkney's argument regarding the Territorial Clause would likewise have implications favorable to internal improvements. The implication of Pinkney's argument was twofold. First, Congress had an implied power to "manage" its property to increase its value (e.g., by obtaining interest on its "treasure" by making deposits in the Bank). Second, the Territorial Clause could imply powers beyond

341 See 4 MARSHALL, supra note 199, at 392-93 (emphasis added) (describing the utility of banking institutions in commercial countries).

342 See McCulloch, 17 U.S. (4 Wheat.) at 325 (referencing Daniel Webster's arguments from his representation of the Bank). 
regulations acting directly within or upon the territories. Such an argument could support an implied power to build roads going to the territories, which would increase immigration to them and promote statehood. It could also support building roads going to public lands outside or within the states, since that would certainly increase their sale value. Marshall did not discuss these facets of the Territorial Clause argument.

Equally significant was Marshall's avoidance of the argument that the national government had an implied power to impose a uniform national currency. Such a power had been derived by others from the nature of sovereignty itself, or from a synergistic reading of several clauses of the Constitution. Pinkney argued that " $[t]$ he power of erecting corporations ... is a necessary means of accomplishing the ends of all governments. It is an authority inherent in, and incident to, all sovereignty." ${ }^{433}$ In other words, while the power of incorporation was only ever a means to execution of a power, it is potentially a means to any and all powers. As we have seen, both Hamilton in 1791 and Calhoun in 1816 had argued in more far-reaching fashion that the power to impose a uniform national currency was an inherent attribute of sovereignty. ${ }^{344}$ Whereas Pinkney and Webster were making the point that incorporation was not in itself a "great power," but always a means to executing a more important and substantive power, Hamilton and Calhoun were suggesting that a great substantive power could be implied through a synergistic reading of several clauses relating to money. Marshall did not venture to adopt, or even acknowledge this latter, more nationalistic argument. The Supreme Court would embrace the Hamilton-Calhoun argument in the third Legal Tender Case (inaptly citing McCulloch!) in 1884. ${ }^{345}$ Marshall merely says that the challenge to an implied power under the Tenth Amendment's reservation of rights to the states must "depend on a fair construction of the whole instrument." "346 But even if this suggests a synergistic interpretation, Marshall does not actually employ one. Fiscal operations are logistical elements attaching independently to each of several powers (taxing, borrowing, spending, war, etc.), and do not constitute a more general power implied by combining those several. Contrast that with Calhoun's claim of a federal power to ers of sovereignty). Webster made a similar point. See id. at 326.

344 See supra text accompanying notes 175, 223 (articulating the extent of Hamilton's and Calhoun's viewpoints on the connection between legal tender and sovereignty).

345 Julliard v. Greenman, 110 U.S. 421, 449-50 (1884).

346 See McCulloch, 17 U.S. (4 Wheat.) at 406 (narrowing the scope of Marshall's comments). 
regulate the currency-stemming from various more specific constitutional clauses. Marshall, for his part, does not embrace the idea that the whole of a cluster of constitutional provisions may be greater than the sum of its parts, or may together imply a more general power.

The best case to be made for teasing some endorsement of internal improvements out of McCulloch comes from two passages. First, the above quoted "vast powers" paragraph might have pleased Hamilton or Henry Clay, particularly the suggestion that "[t]he sword and the purse, all the external relations, and no inconsiderable portion of the industry of the nation, are entrusted to its government." ${ }^{347}$ That language is nationalistic but highly abstract. When we look at Marshall's concrete examples, we can find this passage, which Kent Newmeyer interprets as Marshall's “override” of Madison's Bonus Bill veto: ${ }^{348}$

Throughout this vast republic, from the St. Croix to the Gulph of Mexico, from the Atlantic to the Pacific, revenue is to be collected and expended, armies are to be marched and supported. The exigencies of the nation may require that the treasure raised in the north should be transported to the south, that raised in the east conveyed to the west, or that this order should be reversed. eignty). For a full quotation of the passage, see supra text accompanying note 337.

348 See Newmyer, supra note 34, at 880 ("Marshall's implied powers doctrine made an amendment unnecessary-a point which became abundantly clear when, in an obiter dictum, he referred to the need for federal improvements to bind together the territories acquired in the Adams-Onis Treaty of 1819."). Newmyer refers to the passage in $\mathrm{McCul}$ loch referring to "this vast republic, from the St. Croix to the Gulph of Mexico." McCulloch, 17 U.S. (4 Wheat.) at 408.

349 Id. (emphasis omitted) (illustrating that even Marshall's more concrete examples remain vague and abstract). Jack Balkin suggests that this language shows Marshall peering into the future and outlining a prophetic image of the continental republic that would not be realized for decades. See Jack M. Balkin, The Use that the Future Makes of the Past: John Marshall's Greatness and its Lessons for Today's Supreme Court Justices, 43 WM. \& MARY L. REV. 1321, 1336-37 (2002) (suggesting that Marshall engaged in "prophecy"). That seems to make too much of the quotation. Marshall himself disavowed any aggrandizing intentions in writing that passage, pointing out that it accurately described current national boundaries plus territorial claims. Dismissing Hampden's "charge of having "pompously swelled, and greatly exaggerated' the limites [sic] of the United States," Marshall asks rhetorically, "[i]s not Louisiana bounded by the Gulph of Mexico to the south? ... And do we not, independent of our unratified treaty with Spain, claim the mouth of the Columbia, which empties into [the Pacific] [O]cean?" John Marshall, A Friend of the Constitution Essays, ALEXANDRIA GAZETTE, July 3, 1819 reprinted in MARSHALl's DEFENSE, supra note 72, at 182. Marshall may also, more prosaically, have been hoping to curry favor with Jeffersonian opponents of the Bank by attempting to show that the Bank's operations could actually serve their projects and interests involving westward expansion. 
Do these quotations, separately or together, suggest it is necessary and proper for Congress to build a road? Probably not. Both passages are sufficiently ambiguous to support interpretations consistent with Madison's-and, as we shall see, Monroe's—restrictive views on internal improvements.

Let's start with the "vast powers" passage, which refers to the entrustment of industry to the national government. Since Marshall never said-neither here nor in Gibbons v. Ogden ${ }^{350}$ - that interstate commerce included manufacturers, ${ }^{351}$ the passage may be referring only to the interstate trade in goods produced by industry (the "considerable portion"). It might also be understood to refer to tariffs, which nationalists argued could be used for protectionist promotion of domestic industry. And if this is merely an allusion to tariffs, it would represent at most a tepid endorsement of the American System as a whole, reaching only its least controversial plank-protective tariffs had been consistently enacted since the first Congress and would not be seriously contested until a few years after McCulloch. ${ }^{352}$ However one interprets Marshall's reference to industry, it raises this question: if Marshall was willing to reach out in dicta to aspects of the American System, why not offer some dicta clearly indicating that the national government has the power to build a road?

But Marshall does not speak plainly about roads. The second quotation ("St. Croix to the Gulph") is not necessarily about roads, but more likely about the power to move money around the country. Troops are marched and supported-they must be paid. The absence of regional branches of a national bank meant that, as we have seen, troops had to be paid in depreciated state banknotes that were not redeemable in specie and would not even be accepted by the U.S. treasury in payment of taxes. ${ }^{353}$ The Second Bank could issue notes and its regional branches would hold specie reserves with which to redeem them.

Even if we were to read the quotation to refer to roads, Marshall seems unwilling to acknowledge a federal power to build them. Many

\footnotetext{
$350 \quad 22$ U.S. (9 Wheat.) 1 (1824).

351 See infra text accompanying notes 395-96 (noting the absence of Marshall's views on interstate commerce and manufacturing). Howard Gillman has argued that Marshall in Gibbons "made it as clear as he could in a case where the issue was not raised that manufacturing was not part of commerce." Gillman, supra note 42, at 422. Gillman contends that Marshall, like virtually all nineteenth century legal elites, believed commerce was limited to "interstate exchange and traffic." Id. at 423.

352 CURRIE, supra note 182 , at 285-88.

353 See supra text accompanying notes 217-18 (explaining how payment in depreciated banknotes created troop payment issues).
} 
who conceded the implied powers to carry treasure or march armies did not concede that this implied a power to build a road. Marshall made no effort to contradict this view. If anything, he seems to endorse it. In a later example, Marshall addresses the postal power this way:

Take, for example, the power "to establish post offices and post roads." This power is executed by the single act of making the establishment. But, from this has been inferred the power and duty of carrying the mail along the post road, from one post office to another. And, from this implied power, has again been inferred the right to punish those who steal letters from the post office, or rob the mail. ${ }^{34}$

Note that Marshall does not say that the power to establish post roads implies the power to build post roads. A widely held position on the limited-government side of the internal improvements debate maintained that the power to "establish post-roads" simply meant to set postal routes on already-existing roads, rather than to build new ones. ${ }^{355}$ Such roads would have been built by states or state-chartered corporations. Marshall's carefully worded assertion that " $[\mathrm{t}]$ his power is executed by the single act of making the establishment" is entirely consistent with the limited view. ${ }^{356}$ To be fair, in this passage, Marshall was making a different point-to belie the "strict necessity" interpretation of the Necessary and Proper Clause by demonstrating the existence of uncontroverted implied powers that were not indispensably necessary. Nevertheless, this is all Marshall has to say about roads.

Marshall doesn't breathe another word about internal improvements in the rest of the opinion. The strongest indication of Marshall's failure to endorse internal improvements is found in the twopage passage in which he describes examples of implied powers. The list is strikingly lame. The power to establish post offices and post roads implies, not a power to build them, but a power to deliver the

354 McCulloch v. Maryland, 17 U.S. (4 Wheat.) 316, 417 (1819) (emphasis added).

355 See, e.g., Searight v. Stokes, 44 U.S. (3 How.) 151, 181 (1845) (Daniel, J., dissenting) (" $[\mathrm{T}]$ he authority vested in Congress by the Constitution to establish post-roads, confers no right to open new roads, but implies nothing beyond a discretion in the government in the regulations it may make for the Post-office Department for the selection amongst various routes ...."); James Monroe, Views of the President of the United States on the Subject of Internal Improvements, in 2 A COMPILATION OF THE MESSAGES AND PAPERS OF THE PRESIDENTS, 1789-1897, at 157 (James D. Richardson ed. 1898) ("The idea of a right to lay off the roads of the United States on a general scale of improvement, to take the soil from the proprietor by force, to establish turnpikes and tolls, and to punish offenders in the manner stated above would never occur to any such person."). 
mail and "to punish those who steal letters." ${ }^{357}$ A federal criminal code in general is a set of implied powers-though Marshall mentions no other specific crimes except for two crimes against courts, perjury and falsifying records. ${ }^{358}$ Finally, Marshall mentions the power to require that officeholders take an oath. ${ }^{359}$ This is a precedent for an implied power to charter a bank? Spencer Roane laughed at him (rightly) for this one. ${ }^{360}$ What is missing from this list is the legislative precedent for a congressional power to build "light houses, beacons, buoys \& public piers," which Hamilton had identified as "a decisive example" of an implied power. ${ }^{361}$ It had been argued in Congress as a constitutional justification both for internal improvements and for the Bank. Deploying this example would have cemented the connection between McCulloch and internal improvements. Pinkney encouraged Marshall to do it. Jones dared Marshall to do it. Marshall shrank from the challenge.

\section{E. The Decision: Implied Powers}

It remains to consider whether Marshall's interpretation of the general concept of implied powers in McCulloch by itself justifies the aggressive nationalism characterization. In this Part, I argue that Marshall's approach to implied powers reflects moderate, rather than aggressive nationalism. He declines to adopt the most nationalistic available arguments on three related questions: the definition of implied powers, the scope of judicial review under the Necessary and Proper Clause, and the interpretation of enumerated powers.

\section{The Definition of Implied Powers}

The conception of implied powers articulated in McCulloch was more moderate and less aggressively nationalistic than is supposed in the conventional account. The core of McCulloch's analysis is that Congress has "implied powers," which are not specified in the Constitution. These implied powers are "subdivisions" or "minor ingredients" of the "great" or enumerated powers:

A constitution, to contain an accurate detail of all the subdivisions of which its great powers will admit, and of all the means by which they may

Id. at $416-18$.

Id. at 417 .

Id. at 416 .

Spencer Roane, Hampden Essays, RICHMOND ENQUIRER, June 18, 1819, reprinted in MARSHALL'S DEFENSE, supra note 72, at 131-32.

361 See supra text accompanying note 153. 
be carried into execution, would partake of the prolixity of a legal code, and could scarcely be embraced by the human mind. It would probably never be understood by the public. Its nature, therefore, requires, that only its great outlines should be marked, its important objects designated, and the minor ingredients which compose those objects be deduced from the nature of the objects themselves. That this idea was entertained by the framers of the American constitution, is not only to be inferred from the nature of the instrument, but from the language. Why else were some of the limitations, found in the ninth section of the 1st article, introduced? It is also, in some degree, warranted by their having omitted to use any restrictive term which might prevent its receiving a fair and just interpretation. In considering this question, then, we must never forget, that it is a constitution we are expounding. ${ }^{362}$

In sum, there are two kinds of powers, enumerated and implied. The enumerated powers are "the great powers of the national government" and what Marshall equates with "ends." "Implied" powers are the "means" for implementing those ends, and a more specific level of detail, beneath the "great outlines" of what can be covered in a constitution. Moreover, the two categories are entirely separate and distinct. According to Marshall, "a great substantive and independent power... cannot be implied as incidental to other powers, or used as a means of executing them." "363 Marshall's most succinct statement of the principle is this one: "the powers given to the government imply the ordinary means of execution.”364

Applying this framework to the Bank, Marshall insists that the Bank is an ordinary legislative means. Maryland's lawyers had insisted that the Bank "appertains to sovereignty," but, Marshall replied, that makes it no different from any other law, since "all legislative powers appertain to sovereignty." 365 Moreover, Marshall argued, incorporation is not, like the enumerated powers, a legislative end in itself, but always a means. ${ }^{366}$

In fact, the problem of implied powers generally, and of an implied power to incorporate a bank, does not fall into place quite so easily. ${ }^{367}$ A great deal can be said on this subject, but for present pur-

McCulloch, 17 U.S. (4 Wheat.) at 407 (emphasis omitted).

Id. at 411.

Id. at 409 .

Id. at $409-10$.

Id. at 411 .

Why, for instance, do we need to analyze the "ordinary means of execution" of an enumerated power as another type of "power" at all? Since legislative power can only be implemented by the making of laws, executing granted legislative powers should not necessarily be viewed as a different kind of power. And "means to an end" versus "end in itself" is not a consistent touchstone to distinguish enumerated from implied powers, because at least some, if not most, enumerated powers are means to other legislative ends. Marshall 
poses, one observation suffices. The Second Bank-which Andrew Jackson would soon be calling a "Monster"-was a major power center. ${ }^{368}$ Engaged in far more than mere "fiscal operations" of the government, it exerted control over some 300 state banks by $1819 .{ }^{369} \mathrm{It}$ strains Marshall's scheme to the breaking point to characterize the Second Bank as a "subdivision" or "minor ingredient" of one of the enumerated powers-except, perhaps a broadly construed commerce power. This conceptual difficulty stems directly from Marshall's dogged unwillingness to acknowledge that there might be implied powers comparable in substance and "greatness" to at least some enumerated powers-reflecting, in turn, Marshall's determination to avoid more aggressively nationalist formulations of implied powers.

Marshall might have embraced the argument that a power to impose a uniform national currency was implied by the Coinage and Counterfeiting Clauses, in conjunction with the prohibition on state paper issues, or as an attribute of national sovereignty. Such arguments had been advanced by Hamilton and Calhoun in the political arena and were suggested at oral argument. Crucially, both of these versions of the monetary power argument were more nationalistic than Marshall's approach. They would not have conformed to Marshall's tidy "great powers/inferior powers" formula, and he did not adopt either of them.

Pinkney, in arguing for the Bank, had proposed a more nationalistic solution to the general conceptual problem of implied powers than Marshall's great/inferior powers formula. In Pinkney's schematization, the "national objects" were those set out in the preamble: "[a] more perfect union is to be formed; justice is to be established," etc. ${ }^{370}$ Pinkney continues, "[f] or the attainment of these vast objects,

himself seems to have been aware of some of these conceptual problems, because when defending his implied power analysis in subsequent newspaper articles, he tried to change it. In effect, he departed from McCulloch by recognizing three, rather than two, categories: enumerated powers, implied powers, and laws that directly effectuated an enumerated power. Marshall, supra note 72, at 172-76. For a contemporary discussion of some of the issues raised by implied powers, see generally John Mikhail, The Constitution and the Philosophy of Language: Entailment, Implicature, and Implied Powers, 101 VA. L. REv. 1063 (2015) (arguing that, like a corporate charter, the Constitution, especially the Necessary and Proper Clause, gives the national government implied powers to fulfill its purpose). See also William Baude, Rethinking the Federal Eminent Domain Power, 122 YALE L. J. 1738, 1745-55 (2013) (arguing that Marshall's great powers/inferior powers approach is correct and sound); supra notes 40-50 (citing to extensive academic literature on implied powers and the Necessary and Proper Clause).

HOWE, supra note 20, at 376 .

369 HAMmOND, supra note 59, at 145, 197-200.

370 McCulloch, 17 U.S. (4 Wheat.) at 381 (paraphrasing the Preamble to the United States Constitution). 
the government is armed with powers and faculties corresponding in magnitude." ${ }^{371}$ He then proceeds to list the Article I, Section 8 powers. $^{372}$ Instead of limiting himself to two rigid categories, as Marshall did, Pinkney describes a cascade of ends-means relationships depending on the level of specificity of the statute under consideration:

Many particular means are, of course, involved in the general means necessary to carry into effect the powers expressly granted, and, in that case, the general means become the end, and the smaller objects the means.

It was impossible for the framers of the constitution to specify prospectively all these means, both because it would have involved an immense variety of details, and because it would have been impossible for them to foresee the infinite variety of circumstances in such an unexampled state of political society as ours, forever changing and forever improving. How unwise would it have been, to legislate immutably for exigencies which had not then occurred, and which must have been foreseen but dimly and imperfectly .... The statute book of the United States is filled with powers derived from implication. ${ }^{373}$

For Pinkney, all "laws are but means to promote the legitimate end of all government-the felicity of the people." ${ }^{374}$

While Pinkney's approach has its problems, it is plainly more nationalistic than Marshall's. By recognizing that enumerated powers need not be ends in themselves, but can themselves be means to other ends, Pinkney freed his analysis from the constraint of having to minimize all implied powers as necessarily "inferior" to, let alone "subdivisions of," the enumerated powers. Further, Pinkney recognizes that "all laws are means." In this schematization, it becomes unnecessary to assign a separate constitutional status as a "power" to any particular law. Pinkney's account assumes that there is no constitutional difference between laws that resemble "substantive" or "independent" powers and those that appear to be logical "subdivisions." They are all, equally, means; and they are all within congressional power if they subserve any recognized national power, and even in some cases, if they do not, so long as they serve the great objects in the preamble. To be sure, the latter idea sits uncomfortably next to a strict enumeration-based application of the doctrine of limited powers. Marshall seems to have been intent on satisfying his audience that he was thoroughly committed to the doctrine of enumerated

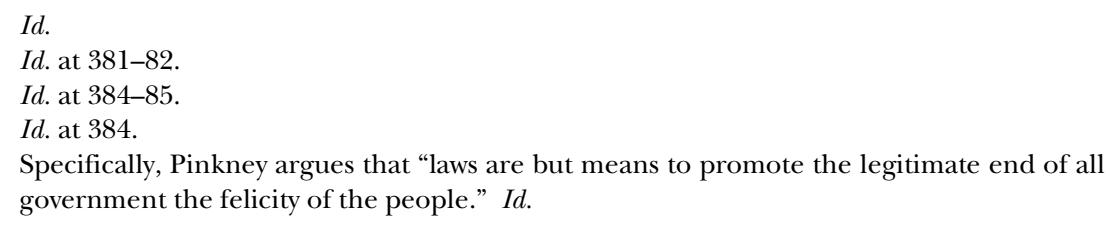


powers, at the expense of a more nationalistic (and possibly more coherent) theory of implied powers that could account for more significant powers that did not fit neatly into a "mere means"/ "inferior powers" box.

\section{The Necessary and Proper Clause and Judicial Review}

McCulloch raises themes of nationalism and judicial review that converge around the question of the Court's deference to Congress's own claims about the scope of its constitutional powers. A deferential approach to the question of scope is inherently more nationalist than a non-deferential approach. The Court cannot create expansive national legislation, such as building a road or chartering a bank, but it can make room for or "invite" such legislation. Deference on the question of the extent of Congress's power is expansive. Thus, an important element of McCulloch's nationalism is its interpretation as a case standing for broad deference to the judgment of Congress as to the scope of its implied powers. Here again, Marshall declined to take the clearest and most nationalistic position available to the Court.

McCulloch's aggressive nationalism reputation stems in large part from its rejection of Maryland's argument that "necessary and proper" should be narrowly construed. Counsel for Maryland argued that the Necessary and Proper Clause "limit[ed] the right to pass laws for the execution of the granted powers, to such as are indispensable, and without which the power would be nugatory"; ${ }^{376}$ and that "it excludes the choice of means, and leaves to Congress, in each case, that only which is most direct and simple." 377 Marshall famously rejected this position. "Necessary" in ordinary speech can mean "convenient, or useful, or essential" and the Constitution elsewhere uses the modifier "absolutely" when intending to use the word "necessary" in a more restrictive sense. ${ }^{378}$ And he argues that the Clause's inclusion among the Article I, Section 8 powers, rather than the Article I, Section 9 limitations, of Congress defeats the idea that the clause is a limitation. $^{379}$ After this, Marshall circles back to his broader argument from constitutional interpretation:

\section{Id. at 413.}

$I d$.

378 Id. at 413-15 (citing U.S. CONST. art. I, § 10, cl. 2 ("No state shall, without the Consent of the Congress, lay any Imposts or Duties on Imports or Exports, except what may be absolutely necessary for executing it's inspection laws ....")).

379 Id. at 419-20 ("The clause is placed among the powers of Congress, not among the limitations on those powers."). 
The subject is the execution of those great powers on which the welfare of a nation essentially depends. It must have been the intention of those who gave these powers, to insure, as far as human prudence could insure, their beneficial execution. This could not be done by confiding the choice of means to such narrow limits as not to leave it in the power of Congress to adopt any which might be appropriate, and which were conducive to the end. This provision is made in a constitution intended to endure for ages to come, and, consequently, to be adapted to the various crises of human affairs. To have prescribed the means by which government should, in all future time, execute its powers, would have been to change, entirely, the character of the instrument, and give it the properties of a legal code. It would have been an unwise attempt to provide, by immutable rules, for exigencies which, if foreseen at all, must have been seen dimly, and which can be best provided for as they occur. To have declared that the best means shall not be used, but those alone without which the power given would be nugatory, would have been to deprive the legislature of the capacity to avail itself of experience, to exercise its reason, and to accommodate its legislation to circumstances. ${ }^{380}$

While on the surface, this language seems to support an aggressive nationalism interpretation of McCulloch, two ambiguities should be noted as an initial matter. First, the repeated references to "crises" and "exigencies" gives traction to a narrower interpretation that McCulloch was meant to track Madison's argument that the power to charter the Bank existed to meet a current emergency, and would recede as the emergency did.

Second, Marshall uses twenty-four different terms (by my count) for his interpretation of "necessary and proper," creating potential ambiguities about the scope of the implied powers. Words and phrases like "convenient," "useful," "conducive," "adapted," and "free use of means" suggest more latitude for Congress. ${ }^{381}$ Those such as "direct," "needful," "requisite," "required" and "essential" seem more restrictive. $^{382}$ Other terms may be in between but suggest some room for judicial second-guessing of Congress. His occasional use of superlatives seemingly suggests that Congress's discretion should aim at choosing "the best," "most convenient," "most appropriate" or "most advantageous[]" means, ${ }^{383}$ while other terms suggest some sort of

$380 \quad$ Id. at 415-16 (emphasis omitted).

$381 I d$. at 409, 413, 415, 419, 420.

382 Id. at 411, 418. Today, essential means "1. absolutely necessary . . 2. relating to the essence of a thing." See Essential, WORDREFERENCE.COM, http://www.wordreference.com/ definition/essential (last visited Sept. 24, 2015) (providing the definition of essential). This order of usage may have been reversed in Marshall's time; obviously he did not use "essential" to mean "absolutely necessary." But see SAMUEL JOHNSON's DictionARY, supra note 330, at 721 (defining essential as "1. [n] ecessary to the constitution or existence of any thing"). 
scrutiny of the congressional decisionmaking process or an objective test of necessity: "really calculated," "plainly adapted," "ordinary," "usual," or "appropriate.,"

The Bank's lawyers argued that the Court should adopt a more deferential posture on questions of congressional power. While they seemed comfortable asserting a strong judicial review role for the Court as a general matter, ${ }^{385}$ their arguments leaned the other way in two key points. First, they suggested that the constitutional question had been settled largely by legislative precedent. As Wirt argued, "[it] ought not now to be questioned, after its exercise ever since the establishment of the constitution, sanctioned by every department of the government." ${ }^{386}$ Deferring to legislative precedent, of course, acknowledges at least a parallel, if not a superior authority of the elected branches to create precedential interpretations of the Constitution.

Second, and related, the Bank's lawyers argued that the judicial test of constitutionality should be limited by setting a very high bar for striking down an act of Congress. Webster argued that the challenger must show that the law "has no fair connection with the execution of any power or duty of the national government, and that its creation is consequently a manifest usurpation." ${ }^{37}$ Pinkney's argument was even more assertive. For Pinkney, " $[t]$ he vast variety of possible means, excludes the practicability of judicial determination as to the fitness of a particular means." 388 The Court can hold a law unconstitutional on this basis only if it appears to be "violently and unnaturally forced into the service, or fraudulently assumed, in order to usurp a new substantive power of sovereignty." ${ }^{389}$ Pinkney argued further that "Congress is, prima facie, a competent judge of its own con-

384 Id. at 408, 409, 421, 423 (emphasis added).

385 For instance, Webster reassured the Court that the Constitution "confides to this Court the ultimate power of deciding all questions arising under the constitution and laws of the United States." Id. at 327.

386 Id. at 352; see also id. at 322 (quoting Webster: "it was not now to be considered as an open question"). As Magliocca has argued, legislative precedent was the prevailing mode of constitutional interpretation for most of the antebellum period. Gerard N. Magliocca, Veto! The Jacksonian Revolution in Constitutional Law, 78 NeB. L. Rev. 205, 220-23 (1999).

387 McCulloch v. Maryland, 17 U.S. (4 Wheat.) 316, 326 (1819). Wirt's argument hewed more closely to the position adopted by Marshall, when he said that "the danger of the abuse [of implied powers] will be checked by the judicial department, which, by comparing the means with the proposed end, will decide whether the connection is real, or assumed as the pretext for the usurpation of powers not belonging to the government...." Id. at 359 .

$388 \quad$ Id. at 387

389 Id. at 387. 
stitutional powers." ${ }^{390}$ Strikingly, he says "powers," not "implied powers." Marshall, in contrast, seems to hold that Congress is merely the judge of the relation between an enumerated and an implied power, and not of the scope of its enumerated powers.

The McCulloch opinion, though equivocal, ultimately settles on a less deferential formula than that urged by Webster and Pinkney. Marshall begins with an aggressive assertion of the Court's role: "[o]n the Supreme Court of the United States has the constitution of our country devolved this important duty" of "decid[ing] peacefully" a question of "the conflicting powers of the government of the Union and of its members." ${ }^{391}$ But then Marshall promptly backtracks, in a long passage admitting that Congress's power to incorporate a bank has been settled by the practice and precedent of the elected branches. $^{392}$ In articulating a deferential approach to the specific question of the Bank's constitutionality, Marshall suggests that there is a high bar for a judicial finding of unconstitutionality: "It would require no ordinary share of intrepidity to assert that a measure adopted under these circumstances was a bold and plain usurpation, to which the constitution gave no countenance." ${ }^{\text {"93 }}$ That the Constitution "gives no countenance" to a "bold and plain usurpation" supports the argument that would be made by James Bradley Thayer eight decades later, that a court can strike down legislative acts only when their unconstitutionality is "so clear that it is not open to rational question." "394 Marshall seems to think that this principle applies, if not across the board, then at least to well-precedented congressional enactments.

Such ambiguity-or perhaps ambivalence-about the roles of the Court and Congress sets a tone that persists throughout the opinion. On one hand, Congress has seemingly unreviewable discretion to determine how best to implement the granted national powers to serve the needs of the people.

[W]e think the sound construction of the constitution must allow to the national legislature that discretion, with respect to the means by which the powers it confers are to be carried into execution, which will enable that body to perform the high duties assigned to it, in the manner most beneficial to the people. ${ }^{395}$

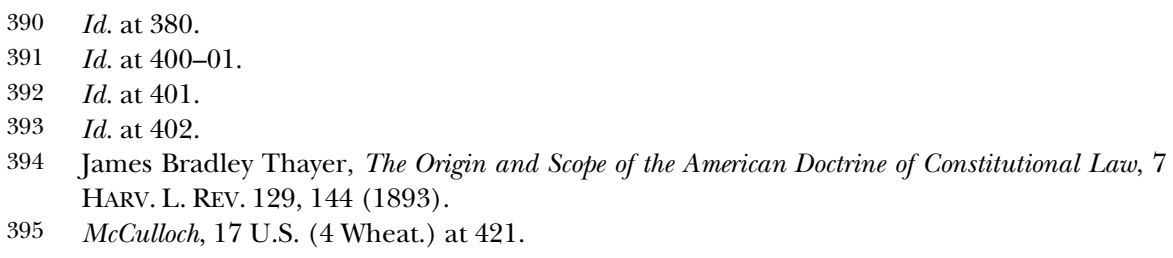


Yes, but (in Marshall's next sentence): "Let the end be legitimate, let it be within the scope of the constitution, and all means which are appropriate, which are plainly adapted to that end, which are not prohibited, but consist with the letter and spirit of the constitution, are constitutional." ${ }^{396}$

Marshall's definition of necessary and proper gives Congress discretion over choice of means. But of course this choice appears to be hedged about with implicit reservations of judicial function. "Let the end be legitimate" means "assuming the end is legitimate"-i.e., that it is within the grant of enumerated powers. But that is always the vexed question: if commerce does not include domestic manufactures, then promoting domestic manufactures is not a "legitimate end... within the scope of the constitution" that can justify the means of building a road or bridge. Marshall does not say it is for the Court to determine whether the end is legitimate-his style is to hedge-but that is a fair implication. As we also know, even if the end is legitimate, the means might run afoul of a constitutional prohibition. Here, Marshall suggests, such prohibitions may be express or implied from the "spirit" of the Constitution-phrasing that greatly expands the potential grounds for judicial limitations of congressional powers.

The other famous passage on this theme is equally ambiguous. As he winds up his conclusion that the Bank is constitutional, Marshall alludes to the broad public consensus that the Bank's operations have been necessary to the government's "fiscal operations." ${ }^{397}$ He then reformulates the statement about congressional discretion and judicial review:

But, were [the Bank's] necessity less apparent, none can deny its being an appropriate measure; and if it is, the degree of its necessity, as has been very justly observed, is to be discussed in another place. Should Congress, in the execution of its powers, adopt measures which are prohibited by the constitution; or should Congress, under the pretext of executing its powers, pass laws for the accomplishment of objects not entrusted to the government; it would become the painful duty of this tribunal, should a case requiring such a decision come before it, to say that such an act was not the law of the land. But where the law is not prohibited, and is really calculated to effect any of the objects entrusted to the government, to undertake here to inquire into the degree of its necessity, would be to pass the line which circumscribes the judicial de- 
partment, and to tread on legislative ground. This court disclaims all pretensions to such a power.

There are two levels of ambiguity in this passage. The first level is the Court's role in second-guessing legislative choice of means. Congress has, Marshall seems to suggest, unreviewable discretion to determine the "degree of ... necessity"-that determination is to be made "in another place" and the Court "disclaims all pretensions" to decide that question. Or does it? The Court will undertake the "painful duty" to invalidate a law that is not "really calculated"-or "plainly adapted," "convenient," "essential" or any of the other adjectives salted through the opinion-to an end within the enumerated powers. We have come to understand this as a kind of rationality review, asking whether a chosen means is logically connected to the identified legitimate ends. We have already seen that Marshall's twenty-four or so descriptors of this idea encompass a range from more to less deferential. There are numerous examples of the $\mathrm{Su}$ preme Court striking down laws as failing a rationality test; before 1937, rationality review was much less deferential than it is today. ${ }^{399}$ More to the point, the test does in fact examine the degree of connection between means and ends; it simply imposes a relatively low threshold for sustaining that connection. This is quite different from a doctrine holding that the existence of any asserted means-ends connection is a political question. ${ }^{400}$ But Marshall does not actually say that the degree of necessity is to be judged deferentially by the Court: he says it is not to be judged by the Court at all-twice in fact in the paragraph quoted above. And in the same paragraph, he says that it is.

The second level of ambiguity goes to legislative ends. Marshall has already implied that the Court reserves this question for itself ("let the end be legitimate"), and he then seems to say so more directly (the "painful duty"). But the word "pretext" in this passage adds further ambiguity. How would the Court decide that Congress has passed a law under a "pretext" of acting within its enumerated powers? Suppose Congress were to enact a law for the building of an intrastate road whose terminus was an interstate or international

$398 \quad I d$

399 Compare Lochner v. New York, 198 U.S. 45 (1905) (striking down economic regulation as violating rationality review) and Morehead v. New York ex rel. Tipaldo, 298 U.S. 587 (1936) (same) with United States v. Carolene Products Co., 304 U.S. 144 (1938) (upholding economic regulation under more deferentially formulated rationality review) and Ferguson v. Skrupa, 372 U.S. 726 (1963) (same).

400 Cf. Magliocca, supra note 10, at 150-51 (arguing that subsequent cases interpreted $\mathrm{McCul}$ loch as making the means-ends relationship a non-justiciable political question). 
port. Congress could argue that the road was "convenient" or "plainly adapted" to promote interstate navigation-something Marshall deemed indisputably a matter of commerce. But it might have been argued in the 1820 s that road travel, in contrast to navigation, is not commerce; and that the navigation hook was a mere pretext for internal improvements-an illegitimate end that violated the "spirit" of the Constitution. In order to reach such a conclusion, a court would have to reason that the road was not sufficiently "necessary" ("convenient," "conducive," etc.) to navigation-thereby, judging the "degree of its necessity" non-deferentially. The word "pretext" implies a lack of deference, a de novo second-guessing of a claimed legislative justification; and such an analysis spills over into a judgment of the relation of means to that end.

The McCulloch opinion thus gives plenty of ammunition to both sides of a debate over the role of the Court and the standard which it will apply. Each time Marshall claims that the Court must defer to Congress's legislative choices, he tempers that claim by asserting the Court's power to second guess that choice. Unsurprisingly, McCulloch has frequently been cited by later Courts in non-deferential decisions, in just this manner, to justify striking down acts of Congress on matters that arguably fell well within its discretion about means. ${ }^{401}$ Commentators have likewise disagreed about how rigorous the test is. While adherents of the aggressive nationalism thesis take McCulloch as authority for judicial deference on the question of means, some eminent scholars have argued that Marshall's test was more rigorous. White observes that, while McCulloch gave congressional implied power an "apparently broad scope," Marshall took pains to point out limits on implied powers so as to deny charges that he was a "consolidationist." 402 Currie found McCulloch "unmistakable" in asserting that "incidental authority must not be so broadly construed as to subvert the basic principle that Congress has limited powers." ${ }^{403}$ My point is

401 See, e.g., Nat'l Fed. of Indep. Bus. v. Sebelius, 132 S. Ct. 2566, 2593 (2012) (opinion of Roberts, C.J.) (plurality opinion) (holding the individual mandate is not sustained by the commerce power); Carter v. Carter Coal Co., 298 U.S. 238, 291 (1936) (striking down the Bituminous Coal Act); Bailey v. Drexel Furniture Co. (Child Labor Tax Case), 259 U.S. 20, 40 (1922) (striking down the child labor tax); United States v. Harris (The Civil Rights Cases), 106 U.S. 629, 635-636 (1883) (striking down the 1875 Civil Rights Act); Hepburn v. Griswold, 75 U.S. 603, 625 (1870) (holding that Congress has no power to issue paper money).

402 WhitE, supra note 32, at 550; see also id. at 8 ("'Consolidation' referred to the opportunities for federal judges to usurp the prerogatives of state courts or state legislatures and thereby 'consolidate' the power of the Union."). 
not that White and Currie are necessarily correct, but rather that their interpretations are plausible, thereby underscoring the ambiguous nature of Marshall's purported deference to Congress.

\section{Implied versus Enumerated Powers}

At the end of the day, the claim that McCulloch was a "sweeping" nationalist decision depends on implied powers and their relationship to enumerated powers. To be sure, deference to congressional judgments on the "degree of necessity" of a chosen means of executing an enumerated power favors a relatively broader rather than narrower scope for congressional power. But this scope, as Marshall also points out, occurs within the limits of the enumerated powers. If the Commerce Clause is limited to regulating trade in goods plus navigation, and if the Postal Clause is construed to authorize only the selection, and not construction, of post roads, then the enumerated powers might not extend to a power to build roads.

Marshall treads carefully to avoid committing the Court to a "liberal" construction of enumerated powers. Hamilton had argued that "the powers contained in a constitution of government, especially those which concern the general administration of the affairs of a country, its finances, trade, defence, \&c. ought to be construed liberal$l y$, in advancement of the public good." ${ }^{404}$ Pinkney, at oral argument on behalf of the Bank, had pressed the argument that " $[i] \mathrm{t}$ is the duty of the Court to construe the constitutional powers of the national government liberally...." ${ }^{405}$ Marshall agrees with Hamilton that constitutional interpretation requires interpreting "the whole instrument" great powers on which the welfare of the nation essentially depends." ${ }^{407}$ But the McCulloch opinion never uses the terms "liberal" or "broad" as descriptors of proper constitutional interpretation, instead claiming that the Constitution should be given a "fair" or "just" construction. ${ }^{408}$ Certainly, Marshall could have deployed the terms "fair" and "just" with a wink, as if to say "my friends all understand I really mean 'broad' and 'liberal."' But a fair reading of Marshall should

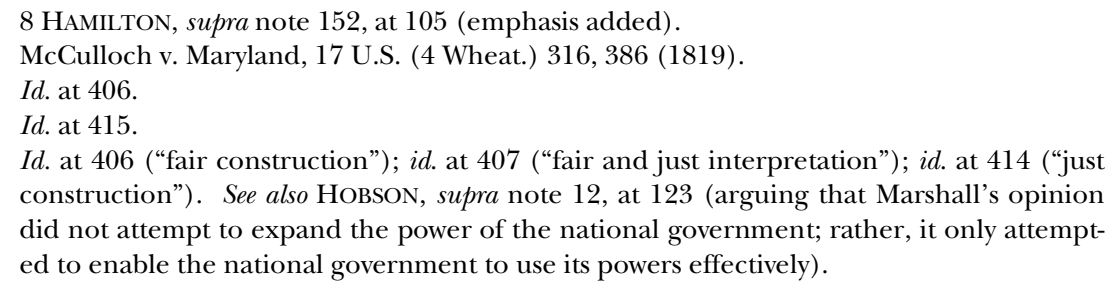


start from the presumption that he meant what he said, and only find an unstated meaning if the context supports it.

Despite its various references to the enumerated powers of the national government as "great," "ample," and "vast," 409 we misconstrue this language by reading it through an aggressive nationalist lens. These terms can have many shades of meaning, including "important; weighty," or "chief; principal." seem to be the meanings Marshall had in mind, because he used the terms to distinguish between the enumerated ("great") powers and the secondary ones, which are means of their execution. For example, incorporating a bank is not found among the "enumerated" powers because it is not "a great substantive and independent power." "411 Marshall tells us that "[i]t can never be pretended that these vast [enumerated] powers draw after them others of inferior importance, merely because they are inferior." ${ }^{\text {"12 }}$ The "vast portion of [sovereignty] which is granted to the general government" clearly means "important" rather than broad in scope, because Marshall emphatically reminds us that the national government is "limited in its powers." 413

Moreover, McCulloch stops short of saying that the Court should defer to congressional judgments interpreting the scope of the enumerated powers. Here, significantly, Marshall parts ways with the more nationalist arguments made to the Court. Pinkney and Webster did not offer extended analyses of the enumerated powers, but they at least put them on the table and at least implicitly suggested that the entire question of whether an implied power was within the scope of the enumerated powers was one requiring judicial deference to congressional judgments. ${ }^{414}$ By implication, that included deference to Congress's judgment on the scope of the Clause. Pinkney was more explicit, when he argued that Congress was the prima facie

409 See McCulloch, 17 U.S. (4 Wheat.) at 400 ("great operations of the government"); id. at 404 ("great and sovereign powers"); $i d$. at 407, 415, 421, 424 ("great powers"); id. at 408 ("vast powers"); $i d$. ("ample powers, on ... which the happiness and prosperity of the nation so vitally depends ...."); $i d$. at 418 ("great objects").

410 See SAmuel Johnson's Dictionary, supra note 330, at 410 (noting that "great" can be synonymous with "chief" or "principal"); $i d$. at 908 (explaining that "vast" can be synonymous with "great").

411 See, e.g., McCulloch, 17 U.S. (4 Wheat.) at 407, 410-11 ("Although, among the enumerated powers of government, we do not find the, word "bank" or "incorporation," we find the great powers to lay and collect taxes; to borrow money; to regulate commerce; to declare and conduct a war; and to raise and support armies and navies.").

412 Id. at 407-08 (emphasis added).

413 Id. at 406.

$414 I d$. at $378-79$. 
judge of its own powers. ${ }^{415}$ For Marshall, however, the "necessary and proper analysis" was analytically separate from the scope of the enumerated powers. We know this because he avoided analyzing the scope of any enumerated powers in McCulloch, so intent was he to avoid embroiling the Court in any controversy over their scope.

McCulloch therefore left open the question of whether any deference should be given to Congress on interpreting the scope of enumerated powers. This question was answered in Gibbons v. Ogden, ${ }^{416}$ where Marshall once again took a moderate rather than aggressively nationalistic position. ${ }^{417}$

\section{EPILOGUE: INTERNAL IMPROVEMENTS AFTER MCCULLOCH}

No case raising the constitutionality of internal improvements reached the Marshall Court following McCulloch. But two further episodes of the Marshall Court shed additional light on the meaning of McCulloch. The first is an interchange between Chief Jusice John Marshall and President James Monroe following the latter's veto of the Cumberland Road Tollgate Bill. The second is the Court's opinion in Gibbons v. Ogden.

\section{A. Marshall, Monroe, and the Cumberland Road Tollgate Veto}

A significant episode in the story of McCulloch and internal improvements occurred outside of court, three years after McCulloch was issued. The episode involved one of the largest internal improvements projects to that time, the Cumberland (or National) Road. Started during the Jefferson administration, this multi-year federal project contemplated an interstate highway from Maryland to Ohio. ${ }^{418}$ With the still-incomplete Cumberland Road in extreme need of repair to its completed sections, the Senate in 1822 voted to appropriate $\$ 9,000$ for road repairs. ${ }^{419}$ But House members objected to devoting further federal tax dollars to the seemingly interminable project, arguing that users of the road should start bearing the cost of its maintenance. ${ }^{420}$ In response, the Senate proposed a bill to erect tollgates on the Cumberland Road and use the tolls to preserve and repair the road; an additional provision of the bill would make it a

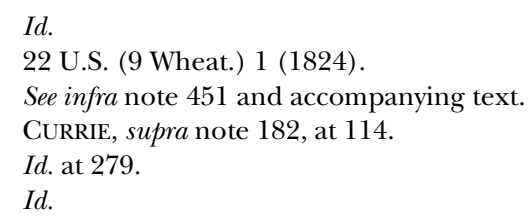


federal crime to evade the duty to pay the tolls. ${ }^{421}$ The use of tollgates for road revenues was long established on public and private roads within the states. The only novelty was the federal government's use of this technique. The bill passed both houses without significant debate. $^{422}$ On May 4, 1822, Monroe vetoed the bill, arguing in his short veto message that the bill implicitly asserted "a complete right of jurisdiction and sovereignty for all the purposes of internal improvement," which Congress does not have and which cannot be granted by state consent. ${ }^{42}$

In an unusual gesture, Monroe expanded on his veto message by issuing a 29,000 word disquisition entitled Views of the President of the United States on the Subject of Internal Improvements. ${ }^{424}$ Though turgid and littered with flawed or sketchy arguments, the essay offered one creative and significant piece of pragmatic constitutional reasoning. More significantly for students of the Marshall Court, Monroe had the essay printed in pamphlet form and sent to various political luminaries, including the Justices of the Supreme Court. ${ }^{425}$ Three of the Justices, including Marshall, sent letters to Monroe in reply. This incident has been reported by various legal historians as an unprecedented instance of the Supreme Court offering an advisory opinion to the President. ${ }^{426}$ Monroe's unusual essay thus warrants consideration as an important state paper, both for its own merits and for the light it sheds on Marshall's constitutional thought.

\section{Monroe's Pamphlet}

Monroe's pamphlet in essence offers a compromise between strict constructionists and pro-internal improvements nationalists, reflecting both his own mixed feelings on the issue and the consensus na-

\footnotetext{
$421 \quad I d$.

$422 I d$. at $278-79$.

423 Monroe, supra note 355 , at 142.

424 Id. at 144.

425 See Donald G. Morgan, Justice William Johnson 122-25 (1954) (noting that Monroe circulated the pamphlet among his friends, including the justices); 2 CHARLES WARREN, THE SUPREME COURT IN UNITED STATES History 55-57 (1923) (noting that the pamphlet was received by the Justices).

426 See HowE, supra note 20, at 213 (discussing modern lawyers' surprise at Justice William Johnson's advisory opinion written to Monroe, advising that the federally funded internal improvements were constitutional); MORGAN, supra note 425, at 122-23 (noting that the Justices gave an almost advisory opinion in response); 2 WARREN, supra note 425, at 55-57 (stating that the Court gave an unofficial opinion in response to the pamphlet).
} 
ture of his presidency more broadly. ${ }^{427}$ Monroe argued that the Cumberland Road Tollgate Bill, with its provision for tollgates and criminal law enforcement, implied a "system of internal improvement," requiring a constellation of powers that Congress did not have. These powers extended beyond merely charting and constructing the road, to include also powers to condemn the underlying land; to build tollgates or houses and collect tolls; and to assert federal criminal jurisdiction over the road (to protect the road from toll evasion, wanton infliction of damage and presumably robbery of passengers). ${ }^{428}$

But, Monroe argued, no such constellation of powers could be implied from any enumerated power. Without naming the case, Monroe flagrantly disregarded McCulloch's formulation regarding implied powers and the Necessary and Proper Clause: " $[\mathrm{w}]$ hatever is absolutely necessary to the accomplishment of the object of the grant, though not specified, may fairly be considered as included in it. Beyond this the doctrine of incidental power can not be carried." ${ }^{429}$ With respect to the enumerated powers argued by internal improvements supporters as constitutional grounds, Monroe offered stingy interpretations. For example, the power to "establish . . post roads," he argued, was merely a power to designate mail routes on existing roads, whose "jurisdiction and soil remain[] to the State, with a right in the State ... to change the road at pleasure." ${ }^{330}$ In a series of unpersuasive arguments, Monroe went on to reject the war, territories and commerce powers as grounds from which a road-building or internal improvements power could be implied. ${ }^{431}$ He asserted that the Federal Government lacked any power of eminent domain within state borders. $^{432}$ Finally, he dismissed the Commerce Clause in a strange and conclusory argument. ${ }^{433}$

427 Monroe's eight years in the White House, 1817-1825, have been dubbed the "era of good feelings" due their veneer of consensus politics. See Howe, supra note 20, at 146-47 (explaining that Monroe was elected almost unanimously).

428 Monroe, supra note 355, at 155-56, 158-59; see also Madison, supra note 220, at 142 ("A power to establish turnpikes with gates and tolls, and to enforce the collection of tolls by penalties, implies a power to adopt and execute a complete system of internal improvement.").

429 Monroe, supra note 355, at 158.

$430 \quad I d$. at 157.

431 Id. at $159-62$.

432 "I believe that very few would concur in the opinion that such a power exists." Id. at 156. See also id at 168 (claiming that the national government's "right to take [private property] at valuation" cannot "be sustained").

433 Id. at 162 . Monroe baldly asserted that the clause was intended primarily to nationalize control over foreign commerce, and only secondarily to regulate interstate commerce. 
Despite these strict constructionist objections, Monroe actually favored internal improvements, and wished to find some common ground with the nationalist wing of his party. He threaded this conceptual needle by arguing that there was a constitutionally dispositive difference between building a road and having jurisdiction over it. Jurisdiction meant the "complete system of internal improvement" that was constitutionally prohibited. But a road could be built by federal contractors, without pretending to carry federal jurisdiction in tow, by applying money appropriated under the spending power. To sustain this conclusion, Monroe adopted an interpretation of the spending power similar to the view that would be embraced by the twentieth century Supreme Court: while the spending power did not confer a power to regulate, it did authorize appropriations to spend on "great national" rather than "strictly local" purposes. ${ }^{434}$ After completing his constitutional analysis, Monroe renewed his call for a constitutional amendment, "the only mode in which" an internal improvements power could be granted " $[\mathrm{i}] \mathrm{f}$ it is thought proper to vest this power in the United States." ${ }^{\text {"35 }}$ But Monroe had to know, based on the failure of such an amendment in 1817, that such prospects were dim, and that the renewed call for an amendment simply underscored his assertion that the great regulatory powers of the government (those other than the spending power) did not impliedly authorize internal improvements.

Monroe's constitutional analysis was bookended by passages extolling the "incalculable" "advantages which would be derived from [internal] improvements." 436

Good roads and canals will promote many very important national purposes. They will facilitate the operations of war, the movements of troops, the transportation of cannon, of provisions, and every warlike store, much to our advantage and to the disadvantage of the enemy in time of war. Good roads will facilitate the transportation of the mail, and thereby promote the purposes of commerce and political intelligence among the people. They will by being properly directed to these objects enhance the value of our vacant lands, a treasure of vast resource to the nation. ${ }^{437}$

Since no power over internal improvements was "mentioned or even glanced at" in the discussion of four international trade "measures" prior to the constitutional convention, he inferred that "no pretension" to such a power was "set up" with regard to foreign commerce. A fortiori, it would not exist as to interstate commerce. Id.

$434 I d$. at $164-67$.

435 Id. at 179.

436 Id. at $176-77$.

437 Id. at 167. 
Monroe was making the point that these internal improvements promote the general welfare and thus come within his spending power rationale. But especially considering that Monroe sent this pamphlet to the Justices, this passage comes across as a taunting challenge to the merely three-year-old precedent of McCulloch. Monroe says quite plainly that good roads and canals are conducive, convenient, and well-adapted to the ends set forth in the war, postal and commerce powers. If McCulloch were authoritative and binding on implied powers generally then the above-quoted passage would have made a good case for implying a congressional power over internal improvements. But for Monroe, who rejected McCulloch's implied powers formula early in the essay, this paragraph implied no such power.

\section{The "Advisory Opinion"}

Monroe sent copies of his internal improvements pamphlet to the Justices, three of whom, including Marshall, sent letters to Monroe in reply. Justice Joseph Story's response was the most appropriate example of what we would expect from judges interacting with the political branches:

Upon the constitutional question, I do not feel at liberty to express any opinion as it may hereafter perhaps come for discussion before the $\mathrm{Su}-$ preme Court; but I rejoice that the wisdom and patriotism of the statesmen of our country are engaged in developing the materials for a sound judgment on this highly interesting subject.

The "aggressive nationalist" response came from Justice William Johnson:

Judge Johnson has had the Honour to submit the President's argument on the subject of internal improvement to his Brother Judges and is instructed to make the following Report. The Judges are deeply sensible of the mark of confidence bestowed on them in this instance and should be unworthy of the confidence did they attempt to conceal their real opinion. Indeed, to conceal or disavow it would be now impossible as they are all of opinion that the decision on the Bank question completely commits them on the subject of internal improvement, as applied to Postroads and Military Roads. On the other points, it is impossible to resist the lucid and conclusive reasoning in the argument. The principle assumed in the case of the Bank is that the granting of the principal power carries with it the grant of all adequate and appropriate means of executing it. That the selection of these means must rest with the General Government, and as to that power and those means the Constitution

438 Letter from Joseph Story to James Monroe (June 24, 1822), quoted in 2 WARREN, supra note 425 , at 56 . 
makes the Government of the U.S. supreme. Judge Johnson would take the liberty of suggesting to the President that it would not be unproductive of good, if the Secretary of State were to have the opinion of this Court on the Bank question, printed and dispersed through the Union. 439

Johnson's claim to be speaking for the full Court should not be taken at face value. Although the historical record on this unusual incident is quite thin, he almost certainly was not speaking for Story or Marshall, who each wrote directly to Monroe, expressing sentiments at odds with Johnson's letter. ${ }^{440}$

Here is the full text of what Marshall in fact wrote to Monroe on June 13, 1822:

I have received the copy of your message to Congress on the subject of internal improvements which you did me the honor to transmit me, and thank you for it. I have read it with great attention and interest.

This is a question which very much divides the opinions of intelligent men; and it is not to be expected that there will be an entire concurrence in that you have expressed. ${ }^{441}$ All however will I think admit that your views are profound, and that you have thought deeply on the subject. To me they appear to be most generally just.

A general power over internal improvement, if to be exercised by the Union, would certainly be cumbersome to the government, E् of no utility to the people. But, to the extent you recommend, it would be productive of no mischief, and of great good. I despair however of the adoption of such a measure.

With great respect and esteem, I am sure your Obedt J Marshall ${ }^{442}$

If we were to bend over backwards to square this letter with the aggressive nationalism view of Marshall, we might say that Marshall's personal views are buried in the roundabout "not . . . an entire concurrence," while his expressions of agreement-"most generally just" and "the general power"-are insincere blandishments of a Virginia gentleman intended only to convey politeness and respect to the President. But, no. Such an interpretation would attribute to Marshall an almost unbelievable obsequiousness. Story's tactful refusal to

439 Letter from William Johnson to James Monroe, quoted in 2 WARREN, supra note 425, at 5657.

440 Charles Warren apparently did take Johnson's claim to be speaking for "his Brother Judges" at face value. Without any additional evidence, Warren assumed that Johnson "obtained the views of his associates" and that the letter-though undated-was written after the Marshall and Story letters. See 2 WARREN, supra note 425, at 56 \& n.1 (stating that Judge Johnson had obtained the views of his associates).

441 [Sic]. "... in all that you have expressed"? The meaning is the same either way. Letter from John Marshall to James Monroe (June 13, 1822), reproduced in 9 THE PAPERS OF JOHN MARSHALl 236 (Charles F. Hobson, ed., 1998) [hereinafter MARSHALl PAPERS]. Id. (emphasis added). 
engage in substance with Monroe underscores that Marshall easily could, and should, have ended his letter after "you have thought deeply on the subject." Story's and Johnson's letters both demonstrate that inter-branch courtesy did not demand insincere expressions of agreement.

But quibbling over whether Marshall actually held nationalist views on internal improvements but hid them in the Monroe letter, misses the larger point. Whether sincere or not, the letter plainly conveys broad approval of Monroe's essay, and by implication, his veto. Marshall distinguishes himself ("To me ...") from those who would disagree with Monroe. The third paragraph suggests more specific approval of Monroe's argument that the Constitution authorizes internal improvements only in a limited fashion via the spending power. It is not completely clear what Marshall means by a "general power over internal improvement." Such a power is not enumerated, but an aggressively nationalistic interpretation of implied powers could easily imply such a general power from the Commerce Clause. Most major internal improvements projects were, at bottom, intended to promote trade and intercourse among the states. Thus, an internal improvement power implied from the Commerce Clause would have supported something quite general-to an aggressive nationalist, anyway. But Marshall suggests that such a purported implied power would be "cumbersome" and "of no utility to the people," phrasing that sounds a lot like the negation of "conducive, well adapted, essential" - that is to say, not necessary and proper to any enumerated power. ${ }^{443}$

Johnson's letter to Monroe has been fairly referred to by several historians as an "advisory opinion." ${ }^{\text {"44 }}$ No one has ever suggested that Marshall's, too, was an advisory opinion. ${ }^{445}$ Yet it was, and one with much greater potential to damage the fabric of Marshall's supposed positions and the principles of McCulloch. Would Monroe have dismissed Marshall's expressions as meaningless polite blandishments? Would he have read the letter's ambiguity as a cagey expression of nationalism? It seems much more likely that Monroe would have

443 The last two sentences in Marshall's third paragraph ("But, to the extent you recommend ....") are ambiguous. Do they refer to Monroe's spending power proposal, or to his suggestion for a constitutional amendment? Both possibilities refer to a narrower approach to internal improvements than "a general power."

444 See Howe, supra note 20, at 213 (describing as advisory Justice Johnson's opinion to Monroe on the constitutionality of internal improvements).

445 Hobson, for example, says just the opposite. "Story, like JM [Marshall], was circumspect, refusing to express an opinion on the constitutional question ...." 9 MARSHALl PAPERS, supra note 441, at 237 n. 2. 
read the letter self-servingly, as an endorsement from the nation's highest judicial authority of his veto and constitutional reasoning. After all, Monroe sent out the pamphlet precisely to persuade the nation's leaders. Marshall's letter could only have encouraged Monroe to pursue the same course with future legislation.

Marshall must have known that his letter could have this effect; it is thus puzzling that he would have sent the letter in that form if it really contradicted his views. Interestingly, a few years after the letter to Monroe, Marshall expressed a view similar to Johnson's in a private letter to Timothy Pickering: a congressional power over internal improvements "for military purposes or for the transportation of the mail" could "be exercised to great advantage, and, there is much reason for thinking, consistently with the constitution." ${ }^{446}$ But I care less about his privately expressed beliefs than what he was willing to say about internal improvements and McCulloch. In neither the Monroe nor Pickering letters did Marshall suggest that McCulloch or any other decision committed the Court on the question of internal improvements. Johnson plainly demonstrated that a legal thinker of the time could indeed apply McCulloch's analysis of the Necessary and Proper Clause to various enumerated powers to sustain a congressional power to build and maintain the National Road. But the fact is that nothing in McCulloch expressly adopted such an interpretation. As we have seen, Marshall took pains to avoid engagement with questions of internal improvements. Whatever it does and does not tell us about Marshall's personal beliefs, the exchange with Monroe suggests at least that, when it counted, Marshall was reluctant to promote a reading of McCulloch as constitutional authority for internal improvements. ${ }^{447}$

\section{B. Gibbons v. Ogden}

This chapter of the McCulloch story would not be complete without at least a brief mention of Gibbons $v$. Ogden. There, the Marshall Court for the first time interpreted the scope of the commerce power, and held that commerce included navigation. In an opinion that does not cite McCulloch even once, Chief Justice Marshall rejected the argument that the enumerated powers should be strictly construed, but neither did he embrace the argument that they should be liberal-

446 Marshall to Timothy Pickering (March 18, 1828), quoted in HoBson, supra note 12, at 124 \& 231 n. 23.

447 Did the Court? Perhaps only Justice Johnson. See supra notes 439-40 and accompanying text. 
ly or deferentially construed. Marshall might have written an opinion saying that "Congress could reasonably conclude that commerce included navigation," thereby establishing deference to congressional judgments on the scope of enumerated powers. Or he might even have declined to place definitional limits on the commerce power by treating the case as an implied powers question, and holding that trade licenses could be construed by a reasonable Congress as "plainly adapted" to promoting commerce. Instead, Marshall decided that the Court must "settle the meaning of the word" "commerce." ${ }^{448}$ The holding of Gibbons, while giving a victory to federal power, implicitly asserted non-deferential review over the interpretation of enumerated powers.

At oral argument, Daniel Webster had pressed for giving broad scope to the Commerce Clause in either of two ways. One was to construe the clause broadly: "the words used in the constitution, 'to regulate commerce,' are so very general and extensive, that they might be construed to cover a vast field of legislation." ${ }^{449}$ The other was to treat the definition of commerce as open-ended:

It was in vain to look for a precise and exact definition of the powers of Congress, on several subjects. The constitution did not undertake the task of making such exact definitions. In conferring powers, it proceeded in the way of enumeration, stating the powers conferred, one after another; in few words; and, where the power was general, or complex in its nature, the extent of the grant must necessarily be judged of, and limited, by its object, and by the nature of the power.

Presumably, such an approach would give Congress wide legislative authority to exercise implied powers. This seems consistent with legislative precedent, in which it was taken for granted that regulating navigation was necessary and proper to regulating commerce.

Marshall's approach was narrower, however. We can start with Marshall's famous quip, in which he praises Webster's argumentand immediately proceeds to ignore it:

The subject to be regulated is commerce; and our constitution being, as was aptly said at the bar, one of enumeration, and not of definition, to ascertain the extent of the power, it becomes necessary to settle the meaning of the word. ${ }^{451}$

Webster's point was just the opposite: that "commerce" cannot and should not be precisely defined. But Marshall insists on defining it"to settle the meaning of the word"-and he does so in characteristic

448 Gibbons, 22 U.S. (9 Wheat.) at 189.

449 Id. at 14.

$450 \quad$ Id. at 10-11 (emphasis omitted).

451 Id. at 189. 
fashion, adopting a middling view. Marshall rejects the argument limiting commerce to "traffic" or "interchange of commodities," but "settles" the definition as "commercial intercourse." While it is not exactly clear what "intercourse" entails_-does it include banking, for example?-Marshall does explain that it includes passenger navigation. This is not an expansive definition of commerce-it is just broad enough to resolve the case, and leaves unclear whether the door is open to further expansion. Whatever intercourse is, by "settling" the meaning of commerce, Marshall adopts a position less expansive than that urged by Webster.

Marshall's decision to eschew an implied powers approach is another instance of his steering clear of the internal improvements question. As in McCulloch, Marshall seemed determined to avoid taking a position that would commit the Court on the question of building roads. If navigation had been analyzed as "necessary and proper" to a more general power over commerce-a power whose limits are left open, as Webster had urged-then it would be a logical next step to argue that road-building was likewise an implied power. Navigation and road building are both transportation, after all. In Gibbons, once again, Marshall refused to acknowledge the legislative precedent of congressional laws building navigational aids. Although now directly relevant to the question of the scope of the commerce power, to explicitly acknowledge that commerce implies a power to build navigational infrastructure might suggest a power to build roads as well. To be sure, an argument for a road-building power could be constructed out of Gibbons on the theory that commerce includes overland "intercourse" as well as intercourse on rivers, coastal waters and seas. At the same time, opponents of roads could plausibly cite Gibbons for the proposition that commerce defined as trade plus navigation does not encompass the power to build roads, which differ from navigation.

\section{CONCLUSION}

The conventional wisdom holds that McCulloch is a "nationbuilding" opinion, one that offers expansive interpretations of the powers of Congress. This "aggressive nationalism" interpretation reads $M c$ Culloch to set forth a doctrine that implicitly pre-approves national infrastructure projects ("internal improvements"), that supports generous interpretations of enumerated powers, and that endorses Hamiltonian political economy or some other constitutional "vision" of expansive congressional power. 
But the aggressive nationalism thesis misreads McCulloch. As we have seen, Chief Justice John Marshall was far more concerned with avoiding controversy than with affirmatively endorsing expansive congressional power. McCulloch did little to suggest, let alone lead Congress into, assertions of constitutional power over internal improvements, monetary policy, or broadly-conceived regulation of commercial activity. McCulloch upheld the constitutionality of the Second Bank, an institution supported by nationalists but also by mainstream Jeffersonians, including President Madison. To be sure, by affirming the constitutionality of the Bank, McCulloch upheld an institution that could and did assert broad monetary powers. But Marshall's opinion says nothing about the Bank's exercise of such powers-not even to acknowledge the Bank's power to issue the very banknotes that gave rise to the litigation. Instead, he explicitly mentions only its "fiscal operations."

Marshall's opinion reflects a determination to steer clear of all other controversial questions of national power. He refused to embrace arguments to sustain the Second Bank under the Commerce Clause, or any other identifiable enumerated power, thus avoiding the need to construe any enumerated power broadly. He also ignored the argument that the national government had an implied power to impose a uniform national currency and regulate the money supply. In discussing congressional power in McCulloch, Marshall assiduously avoided saying anything that would imply support for internal improvements legislation. While McCulloch said nothing to affirmatively discourage Congress from undertaking aggressively nationalistic legislative initiatives, it also said nothing to encourage such legislation. Marshall can hardly be described as a national builder when he would not even commit to building a road.

McCulloch's analysis of implied powers also falls short of the aggressive nationalist interpretation. Marshall's simple distinction between "great" and "inferior" powers, with implied powers falling into the inferior category, fails to allow for the existence of implied powers that might be parallel in importance to some enumerated onesfor example, a federal power over the money supply. At the same time, Marshall's ambiguous statements about the relative roles of Congress and the Court in deciding whether Congress has a particular implied power, and his profusion of words and phrases to characterize the "necessary and proper" test for implied powers, creates an ambiguous legacy regarding the proper extent of judicial deference to congressional judgments about the scope of national powers. Finally, Marshall refused to expressly embrace the argument pressed by Hamilton, Webster, and Wirt that constitutional powers did not de- 
pend for their existence on contingencies or temporary crises. Instead, Marshall used ambiguous language, equally or perhaps even more supportive of Madison's view that an implied constitutional power expired with the passing of the emergency.

At the end of the day, McCulloch's nationalism is quite limited and middle-of-the-road. Undoubtedly, Marshall's rejection of the strict constructionist approach to implied powers made him more of a nationalist than Madison and Monroe. But the aggressive nationalism thesis places Marshall squarely in the midst of American statesmen who acted affirmatively to expand national territory, infrastructure, wealth and power. But Marshall refused in McCulloch to adopt the arguments of such statesmen as Hamilton, Calhoun, and Clay. $\mathrm{He}$ can therefore hardly be classified as their equal in nationalism.

Many colleagues who have reviewed drafts of this Article have resisted my conclusion by making one or more of the following arguments. My test of aggressive nationalism calls for dicta that would have been out of place in a judicial opinion; Marshall displayed sound judicial craft by asserting positions no more nationalistic than necessary to resolve the Bank's constitutionality; and, by not taking sides in a debate between aggressive nationalists (Hamilton, Calhoun, Clay) and conservative nationalists (Madison, Monroe), Marshall was cleverly husbanding the prestige of a vulnerable Supreme Court.

Significantly, arguments of this type don't rescue the aggressive nationalism thesis, but retreat from it to something else: Marshall the judicious statesman, rather than Marshall the nation-builder. It is certainly possible that, in McCulloch, Marshall hid some aggressively nationalistic personal opinions behind a screen of moderate nationalism; but a decision written in moderately nationalistic terms is hardly evidence of aggressively nationalistic views. Nor is it true that judicial craft requires eschewing the most forceful or far-reaching arguments available to a court in resolving a constitutional controversy; that requirement only applies if the Court's goal is to avoid the forceful, farreaching position. Nor would it have been dicta to acknowledge the Bank's power to issue banknotes as a uniform national currencysince its banknotes were precisely at issue in the case-nor to sustain that power under the Commerce Clause. And as for not taking sides, Marshall may have had good reason to avoid that, but the aggressive nationalism thesis asserts quite bluntly that he did take sides, with the aggressive nationalists. Finally, it might be argued that Marshall's judicial statesmanship in McCulloch was importantly institutionbuilding. Perhaps so. But building up the power and prestige of the Court is only nation-building if nation-building doctrines emanate 
from the Court: on that point, the record seems to be decidedly mixed.

Let me be clear: my argument in this Article is not one about the proper interpretation of the Constitution, and the doctrine of implied powers in particular, but one about the proper interpretation of Marshall and his signature judicial opinion. It may be that the aggressive nationalism understanding of implied powers and the Necessary and Proper Clause is correct-I am inclined to believe it is. But, as I have tried to argue, McCulloch is not the true or the best source of that understanding. The most historically accurate and textually faithful reading of $M c$ Culloch tracks closely with William Nelson's appraisal of Marshall as a jurist who tended to announce only constitutional principles around which there was a substantial consensus. Where constitutional questions provoked deep controversy and lacked a clear consensus, Marshall would classify them as matters for the political branches. ${ }^{452}$ Other legal historians have rightly described Marshall as a moderate rather than aggressive jurist, on whom the aggressive nationalist mantle does not fit well. ${ }^{453}$

If $M c$ Culloch did not-as advertised-lay a foundation for the great expansion of federal legislative power in the twentieth century, then the question then arises: why is McCulloch advertised in that way? The answer to that question is complex, and requires article length treatment in itself. Here, I can offer some speculations. My research into this question suggests that McCulloch's contemporary reputation is the result of two waves of attention lavished on Marshall long after his death. The first came in the late 1890s and culminated in "John Marshall Day," on February 4, 1901. ${ }^{454}$ This brainchild of the American Bar Association was a nationwide celebration of the centennial of Marshall's assumption of the Chief Justiceship, marked by speeches and court closures around the country, as well as a presidential proclamation. It was shortly followed by several Marshall biographies. These events roughly coincided with significant public backlash against the Court for its aggressive use of judicial review to strike down progressive economic legislation, such as the Sherman Antitrust Act and the federal income tax. The second wave, led by Felix Frankfurter and other New Deal lawyers and academics, started dur-

452 Nelson, supra note 26, at 924-25.

453 Hobson, supra note 12, at 123; WhITE, supra note 32 , at 486, 594; Newmyer, supra note 34 , at $886-87$.

454 Adolph Moses, "John Marshall DaY": Series of LetTers and Endorsements in answer to Circular advocating the Celebration of "John Marshall DaY," FEbruary 4, 1901, at 7-8 (1899). 
ing the Court crisis of the 1930s. That intellectual movement sought to preserve the Court's role as the ultimate interpreter of the Constitution while, at the same time, deferring to Congress on economic questions and allowing for an expansive understanding of the scope of national legislative power.

I believe that Marshall's reputation was reconstructed first, to put a face on aggressive judicial review, and later, to put a face on judicial self-restraint cum nationalism. As his biographers vividly showed, Marshall was an unusually accomplished man who led a fascinating life and compared favorably to the men of dubious judgment (Taney and Chase) and mediocrities (Waite, Fuller, and White) who followed him. Institutions need heroes to build loyalty. But because this hero was a judge whose most significant deeds are written legal opinions, the human face needs a case to go with it. McCulloch's ambiguity made it a suitable vehicle for both the judicial supremacy and the judicial self-restraint/nationalism projects. But the complete telling of this story is for another day.

One final note is in order. The argument that Marshall's nationalism has been exaggerated, and McCulloch misread, is not an attack on Marshall. It is hardly his fault that he has been elevated into a mythic symbol, that his interpretations of the Constitution on some questions (but not others) have been taken as more authoritative than the Framers' understanding or the words of the Constitution themselves, and that debates over the meaning of the powers of Congress are at times played out as debates over the meaning of Marshall's opinions in Gibbons and McCulloch. We would do well to remember, at those times, Marshall's own words, that it is not an entry in the U.S. Reports, but rather "a constitution we are expounding." 